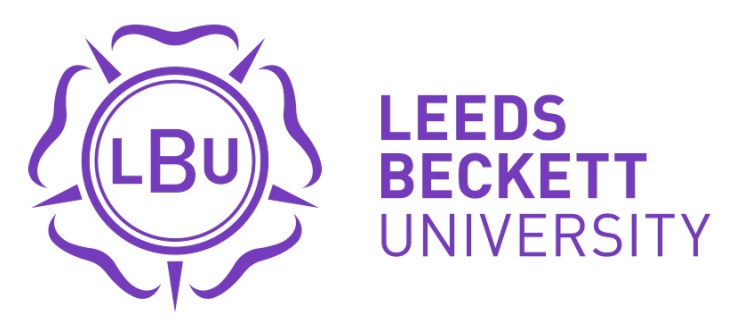

Citation:

Diers-Lawson, AR (2016) A state of emergency in crisis communication: An intercultural crisis communication research agenda. Journal of Intercultural Communication Research, 46 (1). ISSN 1747-5759 DOI: https://doi.org/10.1080/17475759.2016.1262891

Link to Leeds Beckett Repository record:

https://eprints.leedsbeckett.ac.uk/id/eprint/3374/

Document Version:

Article (Accepted Version)

his is an Accepted Manuscript of an article published by Taylor \& Francis in Journal of Intercultural Communication Research on 25 December 2016, available online: http://www.tandfonline.com/10.1080/17475759.2016.1262891

The aim of the Leeds Beckett Repository is to provide open access to our research, as required by funder policies and permitted by publishers and copyright law.

The Leeds Beckett repository holds a wide range of publications, each of which has been checked for copyright and the relevant embargo period has been applied by the Research Services team.

We operate on a standard take-down policy. If you are the author or publisher of an output and you would like it removed from the repository, please contact us and we will investigate on a case-by-case basis.

Each thesis in the repository has been cleared where necessary by the author for third party copyright. If you would like a thesis to be removed from the repository or believe there is an issue with copyright, please contact us on openaccess@leedsbeckett.ac.uk and we will investigate on a case-by-case basis. 


\title{
A STATE OF EMERGENCY IN CRISIS COMMUNICATION: AN INTERCULTURAL CRISIS COMMUNICATION RESEARCH AGENDA
}

\author{
Audra Diers-Lawson, Ph.D. \\ Senior Lecturer, Public Relations \\ Leeds Beckett University
}

Abstract: This article seeks to provide an evidence-based set of recommendations for the development of an intercultural crisis communication research agenda with three goals. First, to provide an advancement in our understanding of the state of crisis communication research in general. Second, to offer a grounded introduction to crisis communication for intercultural scholars who may not be as familiar with the field. Finally to identify three broad evidence-based areas for developing intercultural crisis communication research -(1) representing different cultural perspectives in crisis communication research, (2) placing American crisis research in a global context, and (3) developing cross-cultural comparisons.

Today, organizational crises most often have cultural components - no matter whether we are discussing challenges within countries (Olofsson, 2007) or we are discussing global crises (Gurman \& Ellenberger, 2015). For example, increasing globalization poses unique challenges for practitioners as many do not feel prepared to handle multicultural crises or adapt their response strategies across different cultures (de Fatima Oliveira, 2013). In fact, in Zhao's (2014) discussion of crisis communication in a global context, she suggests that nationalist, statist, classist, and often even cultural analyses are often too static rather than relational and dynamic.

There have been a number of examples of multinational organizations that have failed to effectively respond to crises in an international environment because they have chosen strategies that were culturally 'tone deaf' (An, Park, Cho, \& Berger, 2010). However, today there are a greater number of analyses considering aspects of intercultural communication as a vital part of understanding crisis communication. For example, studies examining cultural factors like power distance in crisis situations (Koc, 2013) or studies of national culture and religious identification in crises (An, et al., 2010; Goby \& Nickerson, 2015; Haruta \& Hallahan, 2003; Jindal, Laveena, \& Aggarwal, 2015; Palmer-Silveira \& Ruiz-Garrido, 2014; Taylor, 2000) all identify the importance of developing culturally-grounded analyses of crisis communication.

Yet, after conducting a systematic review of the English-language crisis communication literature from 1953 to 2015 (see Appendix A for full list of sources analysed) in peer-reviewed journal articles, the state of crisis communication remains shockingly American-centric and fails to reflect the needs and global reality of crisis communication today. There is an opportunity for crisis and cultural researchers to meaningfully advance our understanding of both crisis and intercultural communication in ways that are conceptually complex but also practical. This analysis will not provide a traditional literature review as the discussion of the findings of quantitative findings of the systematic review with selected examples demonstrates the broader trends in the field. Therefore, this article will describe the approach used in the review 
and then build an intercultural crisis communication research agenda by interrogating the intersection of our fields of study.

\section{Methodology and Approach to the Systematic Review}

Within the last few years, there have been two relevant meta-analyses - one tracking public relations scholarship trends (Kim, Choi, Reber, \& Kim, 2014) and one examining crisis communication's interdisciplinary approach (Ha \& Boynton, 2014). While both of these are useful reflections on the state of public relations and crisis communication, they have some meaningful weaknesses. First, the analysis of the trends in public relations scholarship only tracked articles in two journals - Public Relations Review and the Journal of Public Relations Research. While the analysis recognized the importance of globalization and its influence on the field of study through the 1990's and 2000's as well as the emergence of crisis communication also during the same time frame in Public Relations Review, it does not provide a connection between the two and does not represent the global body of work on crisis communication. Second, the examination of crisis communication's interdisciplinary approach was limited to communication-specific journals and did not directly examine culture or global analyses. So, while useful they provide a limited understanding of the whole of crisis communication research.

\section{Population of Crisis Communication Journal Articles}

In order to more effectively assess the state of crisis communication research in a global and multi-disciplinary field of study, I used a different approach to identifying relevant literature to get as broad of a sample of 'crisis communication' journal articles as possible. I used a Google Scholar search with the keyword, 'crisis communication' with peer-reviewed articles presented in order of relevance and then narrowed the search parameter by decade in order to get a more complete list of articles for each decade. I also limited the review to peerreviewed journal articles, excluding books and book chapters. Though this is a limitation, I focused on peer-reviewed journal articles because they are more widely accessible to scholars and many practitioners across industries without additional purchases. At approximately 20 pages into the Google Scholar results, the quality of the results would break down providing mostly irrelevant or repeated citations. This signalled the end of the search for each decade. All relevant and non-repeated articles were included in the population yielding 690 crisis communication articles from 1953 to 2015 (see Appendix A).

\section{Coding}

The following data were captured from each article: year, article type (i.e., conceptual, applied/ case study, or theoretical), research method, the journal, country(ies) directly analyzed in empirical research, primary theory used (where applicable), and keywords or concepts based on author-provided keywords and abstract summaries. In order to identify the primary theory, the abstract and/or text of the articles were analysed for the author(s)' identification of theory applied in the study. In this case, models and theories were treated as equivalent and if they 
were used as an analytical tool for the research, they were measured as a theory for the review. This yielded 278 different journals, presenting empirical findings from 55 different countries, using 99 different theories, and 179 distinctive keywords or concepts identified. Only journals published in English were included in this analysis for two reasons. First, most international conferences and dominant publications are English-language. Second, the author is not sufficiently proficient in other languages to analyse regional variations. Of course, this limits the discussion somewhat; however, given the primacy of English-language publication in our field, the limitation is mitigated.

\section{Analysis Approach}

The resulting data was impractical to analyse without the following data reduction techniques. First, instead of individual journals, Scimago Journal categories (e.g., Management, Communication, etc.) for each journal were identified and coded resulting in six categories medicine and health; science, engineering, and technology; management; social sciences and humanities; communication and language; and industry-specific journals (see Table 1).

\section{Table 1}

Fields of Study in Crisis Communication Journal Articles 1953-2015

\begin{tabular}{|c|c|c|c|}
\hline Summary Journal Category & Sub-Categories & $\mathbf{N}$ & $\%$ \\
\hline Medicine \& Health & $\begin{array}{l}\text { Medicine } \\
\text { Health Policy } \\
\text { Infectious Diseases } \\
\text { Public Health } \\
\text { Environmental and Occupational Health } \\
\text { Health Professions } \\
\text { Emergency Medical Science } \\
\text { Epidemiology }\end{array}$ & 47 & 6.8 \\
\hline $\begin{array}{l}\text { Science, Engineering, \& } \\
\text { Technology }\end{array}$ & $\begin{array}{l}\text { Environmental Science } \\
\text { Computer Science } \\
\text { Engineering } \\
\text { Human-Computer Interaction } \\
\text { Computer Graphics and Computer Aided Design } \\
\text { Applied Mathematics } \\
\text { Modeling and Simulation } \\
\text { Industrial Manufacturing Engineering } \\
\text { Agricultural and Biological Sciences } \\
\text { Food Science } \\
\text { Earth and Planetary Sciences } \\
\text { Chemistry } \\
\text { Planning and Development }\end{array}$ & 96 & 14 \\
\hline Management \& Business & $\begin{array}{l}\text { Business, Management, \& Accounting } \\
\text { Business \& International Management } \\
\text { Management of Technology \& Innovation } \\
\text { Strategy \& Management } \\
\text { Public Administration }\end{array}$ & 443 & 64.5 \\
\hline
\end{tabular}




\begin{tabular}{|c|c|c|c|c|}
\hline & Organizational Behavior \& Human Resource & & & \\
\hline & Management & & & \\
\hline & Finance, Strategy, \& Management & & & \\
\hline & Economics, Econometrics, \& Finance & & & \\
\hline & Marketing & & & \\
\hline & Decision Sciences & & & \\
\hline & Management Information Systems & & & \\
\hline & Industrial Relations & & & \\
\hline & Management & & & \\
\hline & Management of Technology and Information & & & \\
\hline & Management Science \& Operations & & & \\
\hline \multirow[t]{13}{*}{ Social Science \& Humanities } & & & 452 & 65.9 \\
\hline & Arts \& Humanities - Social Science & & & \\
\hline & Sociology \& Political Science & & & \\
\hline & Psychology & & & \\
\hline & Cultural Studies & & & \\
\hline & Education & & & \\
\hline & Social Psychology & & & \\
\hline & Social Sciences & & & \\
\hline & Anthropology & & & \\
\hline & Political Science \& International Relations & & & \\
\hline & Policy \& Law & & & \\
\hline & Urban Studies & & & \\
\hline & Women's Studies & & & \\
\hline \multirow[t]{9}{*}{ Industry Specific } & & & 59 & 8.6 \\
\hline & Development & & & \\
\hline & Tourism & & & \\
\hline & Leisure and Hospitality Management & & & \\
\hline & Safety Research & & & \\
\hline & Sports & & & \\
\hline & Building \& Construction & & & \\
\hline & Safety, Risk, Reliability, Quality & & & \\
\hline & Energy & & & \\
\hline \multirow[t]{6}{*}{ Communication \& Language } & & & 383 & 55.5 \\
\hline & Communication & & & \\
\hline & Language \& Linguistics & & & \\
\hline & Media Studies & & & \\
\hline & Journalism & & & \\
\hline & & Total & 690 & \\
\hline
\end{tabular}

${ }^{1}$ Based on SCImagio Journal Listing Categories. Categories are not mutually exclusive

Categories were not mutually exclusive and all categories were coded for each article. Countries were condensed into regions (see Table 2). Concepts (see Table 3) and theories (see Table 4) were condensed using a constant comparative method (see, e.g., Derrickson \& Brown, 2002) with a couple of exceptions. Because previous analyses (Ha \& Boynton, 2014) and most literature reviews in crisis communication studies identify image repair theory and situational crisis communication theory as the dominant theories in the field, these were left separate for comparison. In addition on the theory identification, if an article did not use a theory that was also coded. 
Table 2

Regions and Countries Studied in Crisis Communication 1953-2015

\begin{tabular}{|c|c|c|c|}
\hline Region & Country & $\mathbf{N}$ & $\%$ \\
\hline \multirow[t]{3}{*}{ North America } & & 422 & 67.8 \\
\hline & Canada & 7 & \\
\hline & United States & 417 & \\
\hline \multirow[t]{6}{*}{ Central \& South America, Caribbean } & & 6 & .9 \\
\hline & Brazil & 1 & \\
\hline & Haiti & 1 & \\
\hline & Mexico & 2 & \\
\hline & Peru & 1 & \\
\hline & Venezuela & 1 & \\
\hline \multirow[t]{6}{*}{ Asia (East) } & & 50 & 7.2 \\
\hline & China & 22 & \\
\hline & Hong Kong & 2 & \\
\hline & Japan & 12 & \\
\hline & South Korea & 10 & \\
\hline & Taiwan & 8 & \\
\hline \multirow[t]{3}{*}{ Australasia } & & 21 & 3 \\
\hline & Australia & 20 & \\
\hline & New Zealand & 12 & \\
\hline \multirow[t]{8}{*}{ Asia (South \& Southeast) } & & 22 & 3.2 \\
\hline & India & 6 & \\
\hline & Indonesia & 1 & \\
\hline & Malaysia & 4 & \\
\hline & Philippines & 3 & \\
\hline & Singapore & 4 & \\
\hline & Sri Lanka & 1 & \\
\hline & Thailand & 2 & \\
\hline \multirow[t]{4}{*}{ Middle East } & & 6 & .9 \\
\hline & Dubai & 2 & \\
\hline & Turkey & 1 & \\
\hline & United Arab Emirates & 3 & \\
\hline \multirow[t]{8}{*}{ Africa } & & 8 & 1.2 \\
\hline & Egypt & 1 & \\
\hline & Kenya & 3 & \\
\hline & Lesotho & 1 & \\
\hline & Rwanda & 1 & \\
\hline & Somalia & 1 & \\
\hline & South Africa & 1 & \\
\hline & Tunisia & 1 & \\
\hline \multirow[t]{11}{*}{ Europe } & & 128 & 18.6 \\
\hline & Belgium & 8 & \\
\hline & Bulgaria & 1 & \\
\hline & Croatia & 1 & \\
\hline & Cyprus & 1 & \\
\hline & Denmark & 8 & \\
\hline & Finland & 4 & \\
\hline & France & 5 & \\
\hline & Germany & 16 & \\
\hline & Greece & 3 & \\
\hline & Ireland & 3 & \\
\hline
\end{tabular}




\begin{tabular}{llc}
\hline & Israel & 4 \\
& Italy & 6 \\
& Latvia & 1 \\
& Lithuania & 1 \\
& Netherlands & 18 \\
& Norway & 6 \\
& Romania & 3 \\
& Russia & 1 \\
& Spain & 10 \\
& Sweden & 21 \\
\hline
\end{tabular}

Table 3

Keywords and Concepts Studied ${ }^{1}$ in Crisis Communication Articles 1953-2015

\begin{tabular}{|c|c|c|c|}
\hline Concept Categories & Concepts & $\mathbf{N}$ & $\%$ \\
\hline Crisis Type & $\begin{array}{l}\text { Transgressions } \\
\text { Organizational Events } \\
\text { Events Outside Control } \\
\text { Reputational }\end{array}$ & 87 & 12.6 \\
\hline Crisis Context & $\begin{array}{l}\text { Accidents } \\
\text { Activism } \\
\text { Advertising } \\
\text { Celebrity } \\
\text { Corruption } \\
\text { Counter branding } \\
\text { Disease } \\
\text { Emergency response } \\
\text { Environmental } \\
\text { Financial } \\
\text { Food/ food quality } \\
\text { Globalization } \\
\text { Health } \\
\text { High reliability organization } \\
\text { International relations } \\
\text { Multinational corporation } \\
\text { Natural disaster } \\
\text { News/ breaking news } \\
\text { Nuclear disaster } \\
\text { Politics } \\
\text { Pop culture } \\
\text { Product harm crisis } \\
\text { Public safety } \\
\text { Scandals } \\
\text { Terrorism } \\
\text { Urban crisis } \\
\text { War/ Cold War }\end{array}$ & 253 & 36.7 \\
\hline
\end{tabular}




\begin{tabular}{|c|c|c|c|}
\hline \multirow[t]{2}{*}{ Industry/ Organization Type } & & 163 & 23.6 \\
\hline & $\begin{array}{l}\text { Agricultural } \\
\text { Airline } \\
\text { Automobile } \\
\text { Defense (national) } \\
\text { Finance } \\
\text { Food manufacturing } \\
\text { Fortune } 500 \\
\text { Hospitality } \\
\text { Journalism } \\
\text { Marketing } \\
\text { Mining } \\
\text { Nonprofit/ Charity } \\
\text { Oil/ Energy } \\
\text { Pharmaceuticals } \\
\text { Police/ Law Enforcement } \\
\text { Public Relations } \\
\text { Public Sector/ Government } \\
\text { Retail } \\
\text { Schools/ Universities } \\
\text { Small Business } \\
\text { Social Movement Organizations } \\
\text { Sports } \\
\text { Technology } \\
\text { Tourism/ Travel } \\
\text { Unions }\end{array}$ & & \\
\hline Crisis Response/ Message Assessment & $\begin{array}{l}\text { Accounts } \\
\text { Ambiguity } \\
\text { Apology } \\
\text { Argumentation } \\
\text { Crisis spokesperson } \\
\text { Dialogic communication } \\
\text { Diplomacy } \\
\text { Discourse } \\
\text { Forgiveness/ atonement } \\
\text { Message effectiveness } \\
\text { Message involvement } \\
\text { Persuasion } \\
\text { Renewal } \\
\text { Response strategies } \\
\text { Rhetoric } \\
\text { Strategic communication } \\
\text { Symbols/ metaphors } \\
\text { Third person effect } \\
\text { Timing } \\
\text { Visual communication }\end{array}$ & 240 & 34.8 \\
\hline Relational Factors & $\begin{array}{l}\text { Relationship management } \\
\text { User-generated content }\end{array}$ & 41 & 5.9 \\
\hline
\end{tabular}

User-generated content 


\begin{tabular}{|c|c|c|c|}
\hline \multirow[t]{6}{*}{ Media Analysis } & & 68 & 9.9 \\
\hline & Agenda setting & & \\
\hline & Media & & \\
\hline & Media effects & & \\
\hline & Media coverage & & \\
\hline & Television & & \\
\hline \multirow[t]{5}{*}{ Crisis Management } & Audits & 162 & 23.5 \\
\hline & Crisis management & & \\
\hline & Decision-making & & \\
\hline & Knowledge management & & \\
\hline & Media relations & & \\
\hline \multirow[t]{4}{*}{ Crisis Planning } & & 41 & 5.9 \\
\hline & Contingency planning & & \\
\hline & Crisis plans/ planning & & \\
\hline & Documentation & & \\
\hline \multirow[t]{4}{*}{ Internal Crisis Management } & & 32 & 4.6 \\
\hline & Human Relations & & \\
\hline & Internal PR/ Employee Relations & & \\
\hline & Team/ Teamwork & & \\
\hline Leadership & & 58 & 8.4 \\
\hline \multirow[t]{3}{*}{ Interorganizational Relationships } & & 15 & 2.2 \\
\hline & Boundary Spanning & & \\
\hline & Strategic Alliances & & \\
\hline \multirow[t]{3}{*}{ Issue Management } & & 26 & 3.8 \\
\hline & Issue Management & & \\
\hline & SWOT Analysis & & \\
\hline \multirow[t]{4}{*}{ Crisis Training \& Education } & & 14 & 2.0 \\
\hline & Pedagogy & & \\
\hline & Simulations & & \\
\hline & Training & & \\
\hline \multirow[t]{6}{*}{ Crisis Assessment } & & 60 & 8.7 \\
\hline & Blame attribution & & \\
\hline & Conflict & & \\
\hline & Sensemaking & & \\
\hline & Severity & & \\
\hline & Urgency & & \\
\hline \multirow[t]{15}{*}{ Organizational Assessments } & & 220 & 31.9 \\
\hline & Crisis history & & \\
\hline & Halo effect & & \\
\hline & Organizational Image & & \\
\hline & Impression management & & \\
\hline & Legitimacy & & \\
\hline & Organizational behaviour & & \\
\hline & Organizational change & & \\
\hline & Organizational charisma & & \\
\hline & Organizational commitment & & \\
\hline & Organizational credibility & & \\
\hline & Organizational culture & & \\
\hline & Organizational identity & & \\
\hline & Power & & \\
\hline & Trustworthiness & & \\
\hline
\end{tabular}




\begin{tabular}{|c|c|c|c|}
\hline & \multirow{6}{*}{$\begin{array}{l}\text { Attitudes } \\
\text { Efficacy (self \& response) } \\
\text { Self-protective behaviour } \\
\text { Susceptibility } \\
\text { Uncertainty }\end{array}$} & & \\
\hline & & & \\
\hline & & & \\
\hline & & & \\
\hline & & & \\
\hline & & & \\
\hline \multirow[t]{12}{*}{ Crisis Outcomes } & & 94 & 13.6 \\
\hline & Community development & & \\
\hline & Crisis outcomes & & \\
\hline & Crowdsourcing & & \\
\hline & Customer loyalty & & \\
\hline & Negative publicity & & \\
\hline & Organizational learning & & \\
\hline & Public opinion & & \\
\hline & Sponsorship & & \\
\hline & Sustainabililty & & \\
\hline & Trauma & & \\
\hline & Word-of-mouth & & \\
\hline \multirow[t]{6}{*}{ Culture \& Cultural Analysis } & & 70 & 10.1 \\
\hline & Cross-cultural comparison & & \\
\hline & Culture & & \\
\hline & Cultural change & & \\
\hline & Individualist/ collectivist & & \\
\hline & Power distance & & \\
\hline \multirow[t]{3}{*}{ Emotion } & & 39 & 5.7 \\
\hline & Emotion & & \\
\hline & Humor & & \\
\hline \multirow[t]{5}{*}{ Information Management } & & 46 & 6.7 \\
\hline & Information clarity & & \\
\hline & Information consumption & & \\
\hline & Information expectations & & \\
\hline & Information sharing & & \\
\hline \multirow[t]{3}{*}{ Demographics } & & 16 & 2.3 \\
\hline & Gender & & \\
\hline & Race/ Ethnicity & & \\
\hline \multirow[t]{5}{*}{ Risk } & & 52 & 7.5 \\
\hline & Risk & & \\
\hline & Risk communication & & \\
\hline & Risk management & & \\
\hline & Risk perception & & \\
\hline \multirow[t]{11}{*}{ Social Media } & & 126 & 18.3 \\
\hline & Big data/ analytics & & \\
\hline & Blogs & & \\
\hline & Digital convergence & & \\
\hline & Engagement & & \\
\hline & Facebook & & \\
\hline & Internet & & \\
\hline & Online community & & \\
\hline & Social Media & & \\
\hline & Technology & & \\
\hline & Twitter & & \\
\hline
\end{tabular}




\begin{tabular}{llcc}
\hline Stakeholders (external) & & $\mathbf{1 0 6}$ & 15.4 \\
Meta-analysis, Methods & Best practices & $\mathbf{1 8}$ & 2.6 \\
& $\begin{array}{l}\text { Meta-analysis } \\
\text { Paradigm influence, philosophy }\end{array}$ & & \\
& Research methods & & \\
Corporate Social Responsibility & & $\mathbf{2 7}$ & 3.9 \\
Ethics & & $\mathbf{2 9}$ & 4.2 \\
Networks & & $\mathbf{1 1}$ & 1.6 \\
\hline
\end{tabular}

${ }^{1}$ Multiple concepts and keywords possible for each article

Table 4

Theories Applied, Developed in Crisis Communication Articles 1953-2015

\begin{tabular}{|c|c|c|c|}
\hline Theory Categories & Theories/ Theory Type & $\mathbf{N}$ & $\%$ \\
\hline None & $\begin{array}{l}\text { Practical } \\
\text { Descriptive }\end{array}$ & 268 & 39.5 \\
\hline Image Repair Theory & & 37 & 5.4 \\
\hline $\begin{array}{l}\text { Situational Crisis Communication } \\
\text { Theory }\end{array}$ & & 38 & 5.5 \\
\hline Stakeholder & $\begin{array}{l}\text { Stakeholder theory } \\
\text { Stakeholder relationship management }\end{array}$ & 19 & 2.8 \\
\hline Psychological & $\begin{array}{l}\text { Decision-making } \\
\text { Conflict management } \\
\text { Impression management } \\
\text { Behavioral resistance } \\
\text { Cognitive appraisal } \\
\text { Congruence theory } \\
\text { Expectancy violation theory } \\
\text { Uncertainty avoidance } \\
\text { Cognitive functional model } \\
\text { Emotional dimensionality theory } \\
\text { Identity theory } \\
\text { Discrepancy theory } \\
\text { Social cognition theory } \\
\text { Self-determination theory } \\
\text { Social approval theory }\end{array}$ & 54 & 7.8 \\
\hline Organizational & $\begin{array}{l}\text { Institutional theory } \\
\text { Organizational behaviour } \\
\text { Systems theory } \\
\text { Sensemaking theory } \\
\text { Network theory } \\
\text { Social capital } \\
\text { Organizational change } \\
\text { Organizational learning }\end{array}$ & 32 & 4.6 \\
\hline
\end{tabular}


Public Relations \& Communication

\section{Management}

Persuasion

Media

Culture

Rhetoric

Attribution

Leadership

Other Crisis Theories
Organizational perception management

theory

Groupthink

Dialogic theory

Argumentation theory

Excellence theory

Theory of publics

Third person effect

Anticipatory impression management

Narrative

Human resource development

Ownership theory

IDEA model

Integrated strategic management model

Brand commitment

Extended parallel process model

Theory of planned behavior

Elaboration likelihood model

Inoculation theory

Media framing

Digital convergence theory

Information exchange theory

Agenda setting

Media richness theory

Diffusion theory

Media dependence theory

Theory of channel complementarity

Dissonance theory

Uses and gratifications theory

7

1.0

Hofstede's dimensions of culture

Cultural trauma

Theory of cultural competence

Public diplomacy

Deliberative rhetoric

Symbolic interaction

Burkean rhetoric

11

1.6

Blame attribution

Attribution theory

Leadership performance

Leader member exchange theory

Situational leadership theory

Crisis knowledge governance 


\begin{tabular}{|c|c|c|c|}
\hline & $\begin{array}{l}\text { Crisis behaviour model } \\
\text { Ethical crisis response } \\
\text { General failure type model } \\
\text { Early warning signals } \\
\text { Crisis, emergency, \& risk communication } \\
\text { model } \\
\text { Stage model for crisis response } \\
\text { Learning in crisis } \\
\text { Strategic crisis management model } \\
\text { Internet crisis potential model } \\
\text { Social mediated crisis communication } \\
\text { Mass, material, access, and motivation } \\
\text { model } \\
\text { Enthymematic crisis rhetoric } \\
\text { Crisis lifecycle model } \\
\text { Integrated crisis mapping model } \\
\text { Crisis management theory }\end{array}$ & & \\
\hline Corporate Social Responsibility & & 1 & .1 \\
\hline Education & Adult learning theory & 1 & .1 \\
\hline Critical & $\begin{array}{l}\text { Critical theory } \\
\text { Gender power theory }\end{array}$ & 8 & 1.2 \\
\hline Contingency & Contingency theory & 8 & 1.2 \\
\hline Issue Management & & 3 & 1.4 \\
\hline Risk Communication & $\begin{array}{l}\text { Risk communication models } \\
\text { Social amplification of risk framework }\end{array}$ & 7 & 1.0 \\
\hline Other & Chaos theory & 2 & .3 \\
\hline
\end{tabular}

${ }^{1}$ Only 1 principle theory was coded per article. Articles whose purpose were theoretical comparison were excluded from this analysis

The data were then analyzed to answer several broad questions. First, what are the key trends in crisis communication research? Second, to what degree does research in the field of crisis communication reflect the need for greater multicultural understanding of crises and people affected by them? Third, what are the key trends in research in each major region? Data were analyzed with descriptive statistics, correlations, regression, and ANOVA and are reported in the research agenda.

\section{An Intercultural Crisis Communication Research Agenda}

The best summary of the story about the state of published journal articles related to intercultural crisis communication research is to say that it is in a dire condition and greatly in need of development in all areas of study. This represents an important development in both the fields of intercultural communication as intercultural issues are fuelling many of the 
conflicts at all levels of society and crises are increasingly global (see, e.g., An, et al., 2010; de Fatima Oliveira, 2013; Gurman \& Ellenberger, 2015; Olofsson, 2007; Zhao, 2014). Therefore, this research agenda will identify some key limitations in our understanding of intercultural crisis communication and also to offer several starting points for research in intercultural crisis communication in order to address these limitations in theory and conceptual development needed in the increasingly multi-cultural organizational reality.

\section{Representing Different Experiences and Voices in Crisis Communication}

The simplest way to begin this story is to ask the question, when scholars and practitioners talk about the field's current understanding of 'crisis communication,' whose voices are being represented and in what contexts? The voice is disproportionately North American and specifically American with 60 percent of all empirical journal articles in crisis communication published since 1953 researching an American point of view (see Table 2). Thus, to talk about 'North American' research is really to talk about research focusing on the United States because there were only seven articles focusing on Canadian crises and the two articles on Mexico were culturally more appropriately grouped with the rest of Latin America in Central America, South America, and the Caribbean. In addition, if the field considers voice and experience more broadly, the 'West's' (i.e., North America and Europe) voice dominates with 83 percent of all articles articulating a developed world and western perspective.

That is not to say that the field of crisis communication is ignoring different cultural experiences. In recent years there has been a modest expansion of voices with research focusing on the US reducing significantly $(r=-.24, p<.00)$ with research in Europe overall $(r=$ $.16, p<.00)$ and Sweden $(r=.09, p<.00)$, in particular, both significantly rising. In addition, there has been a significant increase in representation of Chinese voices in crisis communication research $(r=.09, p<.00)$. Finally, there has been an increasing trend towards studying crisis communication within and between countries worldwide $(r=.17, p<.00)$. However, there are some areas for developing a more effectively grounded understanding of crisis communication in a global context.

\section{Research objective one - develop a more meaningful and global understanding of} crisis communication. In short, continue the existing trend. More research across Europe and China alone is not the answer - the contributions of scholars in these countries is important; however, there is simply a dearth of research reported in journals focusing on Central and South America, the Caribbean, the Middle East, South and Southeast Asia, and Africa. It is problematic that in more than 60 years of research in crisis communication that there are only around 20 articles focusing on South and Southeast Asia, eight on the continent of Africa, six on the broad region of Central and South America plus the Caribbean, and six on the Middle East (see Table 2). Functionally, crisis communication scholars and practitioners know very little about the topic as it applies to the majority of the world's population. I would argue there is no great conspiracy in crisis communication against these regions - it is not an issue of intention, but it is an issue of ease of access. It is not a coincidence that the majority of active scholars in crisis communication happen to live in the regions that are well-researched or where research in crisis is rising. 
However, access is not the most significant barrier for initially developing research focusing on these areas. Certainly, encouraging scholars from these underserved regions is important; however, there is much that those scholars and practitioners outside of these regions can do to initiate more research. Considering the manner in which crisis communication, as a field of study, has developed provides a template for how research underserved regions can be developed.

A template for developing culturally grounded crisis research. Over the last six decades, a clear pattern of conceptual development in crisis communication has emerged. Early stages of research in any region (see Table 5, 6, \& 7) has focused on non-empirical research (M = 2002.86) - particularly conceptual analysis and 'best practice' recommendations ( $\mathrm{M}=$ 2002.13). Then the bulk of the research on crisis communication in the last 60 years has focused on applied or case study research ( $M=2005.95$; see Table 7) with a strong emphasis in rhetorical methodologies ( $M=2005.29$; see Table 8 ) - functionally describing cases and crisis responses from organizations. From there, qualitative analyses of cases began to emerge $(\mathrm{M}=$ 2007.39) followed by cross-sectional research $(M=2008.79)$ along with quantitative $(M=$ 2007.39), and then experimental research $(M=2009.36)$.

\section{Table 5}

ANOVA for the Type of Research and Methodological Development in Crisis Communication

\begin{tabular}{cccccccr}
\hline $\begin{array}{c}\text { Independent } \\
\text { Variable }\end{array}$ & $d f$ & $F$ & $p$ & \multicolumn{1}{c}{ Post Hoc I } & Post Hoc J & I-J & Sig. \\
\hline Type of Research & 2,687 & 16.74 & $<.00$ & $\begin{array}{l}\text { Conceptual \& Best } \\
\text { Practices }\end{array}$ & $\begin{array}{l}\text { Applied/Case Study } \\
\text { Cross-Sectional }\end{array}$ & -3.81 & $<.00$ \\
& & & & Cross-Sectional & -2.66 & $<.00$ \\
& & & & Applied/Case Study & .02 \\
Research Methods & 6,684 & \multirow{2}{*}{7.65} & & Non-Empirical & Qualitative & -5.31 & .05 \\
& & & & & Quantitative & -5.96 & $<.00$ \\
& & & & & Experimental & -7.28 & $<.00$ \\
\hline
\end{tabular}

Notes: The alpha for all tests was set at .05 .

\section{Table 6}

Types of Articles in Crisis Communication Journal Articles 1953-2015

\begin{tabular}{|c|c|c|}
\hline Broad Type of Article & $\mathbf{N}$ & $\%$ \\
\hline Non-data (conceptual, theory, or practical recommendations) & 188 & 27.2 \\
\hline Applied or Case Study & 335 & 48.6 \\
\hline Cross-Sectional & 167 & 24.2 \\
\hline Total & 690 & \\
\hline
\end{tabular}




\section{Table 7}

Methods in Crisis Communication Journal Articles 1953-2015

\begin{tabular}{|c|c|c|c|}
\hline Broad Type of Article & & $\mathbf{N}$ & $\%$ \\
\hline Conceptual/ Best Practices & & 198 & 28.7 \\
\hline Rhetorical & & 199 & 28.8 \\
\hline Qualitative & & 54 & 7.8 \\
\hline Quantitative (questionnaire, content analysis) & & 168 & 24.3 \\
\hline Experimental (quantitative) & & 64 & 9.3 \\
\hline Mixed Method (qualitative \& quantitative) & & 7 & 1 \\
\hline & Total & 690 & \\
\hline
\end{tabular}

This is a sensible evolution because scholars and practitioners need to theorize about the influence of culture on crisis communication in different regions of the world. This allows the field to build up a strong log of case studies of crises based on available media sources using rhetorical methodologies, and then the more difficult work of resolving the access problem begins by finding ways to gain access to people and organizations in these regions (i.e., the point at which the access problem does become an issue). This also suggests that researchers from different regions probably need to build more strategic connections with researchers and practitioners in other parts of the world in order to collaborate on research. Conferences, graduate student recruitment, and networking all represent viable avenues to accomplish these goals along with more organizational collaborations - from corporate to governmental or nonprofit operating in different parts of the world.

\section{Research objective two - consider the U.S. as part of the world community in crisis} communication. Again, discussing 'North American' research is misleading when all but seven of the 422 journal articles focusing on North America are actually analyzing American organizations, it is more accurate to call it U.S. research. Thus, when U.S. companies, crises, or stakeholders are analyzed in crisis communication research there is little cross-cultural analysis, as indicated by the strong negative correlations between research focusing on the U.S. compared to most of the other regions (see Table 8). Certainly, there are a handful of studies like Gonzales-Herrero and Pratt's (1998) tourism marketing crisis comparison of the US and Spain; Haruta and Hallahan's (2003) comparison of airline crisis communications in the US and Japan; An, et al.'s (2010) comparison of crisis response strategy in the US and South Korea; Palmer-Silveira and Ruiz-Garrido's (2014) comparison of US and Spanish annual reports in crisis communication; Hajibaba, Gretzel, Leisch, and Dolnicar's (2015) analysis of crisis resistant tourists; or Jindal, et al.'s (2015) comparison of the American and Japanese auto industry's crisis management strategies. However, there are relatively few of these comparisons suggesting we have little substantial evidence to place the American-centric body of crisis communication research in context of the rest of the world. 
Table 8

Correlations for of Regions Studied in Crisis Communication

\begin{tabular}{|c|c|c|c|c|c|c|c|c|}
\hline Variable & 1 & 2 & 3 & 4 & 5 & 6 & 7 & 8 \\
\hline 1. North America & 1 & & & & & & & \\
\hline $\begin{array}{l}\text { 2. Central, South } \\
\text { America, \& } \\
\text { Caribbean }\end{array}$ & -.07 & 1 & & & & & & \\
\hline 3. Asia (Eastern) & $-.32 * * *$ & $.15 * * *$ & 1 & & & & & \\
\hline 4. Australasia & $-.23^{* * *}$ & $.16^{* * *}$ & .01 & 1 & & & & \\
\hline 5. Middle East & $-.11 * *$ & -.01 & -.03 & -.02 & 1 & & & \\
\hline 6. Europe & $-.64^{* * *}$ & -.05 & $-.11 * *$ & -.05 & .03 & 1 & & \\
\hline 7. Asia (S/SE) & $-.22 * * *$ & $.16^{* * *}$ & .07 & $.11^{* *}$ & -.02 & -.08 & 1 & \\
\hline 8. Africa & $-.17^{* * *}$ & -.01 & -.03 & -.02 & $.14^{* * *}$ & -.06 & -.02 & 1 \\
\hline
\end{tabular}

Notes: $^{*}=$ significant at the .05 level; ${ }^{* *}=$ significant at the .01 level; $\mathrm{N}=622$

Simply reducing or eliminating studies of the U.S. is not the answer to better intercultural crisis communication (ICC) research; the American perspective needs to be considered in comparison with those from other places. This would more meaningfully allow us to understand the degree to which different cultural identities influence crisis communication and in what ways. For example, do/should organizations simply respond to crises differently in different locations? Do people react to crises fundamentally differently in different locations? What factors influence the relative success of crisis communication across cultures? The present body of research gives us a starting point, but we need to actively and constantly compare that with voices from other regions to better understand whether the crisis situation is unique in its communicative needs or whether a deep cultural understanding will substantially improve engagement between organizations and stakeholders to mutually beneficial ends during crises. Certainly no individual study needs to accomplish all of these goals; however, beginning to juxtapose findings from the United States with more directly comparable studies analyzing different populations would be meaningful where data collected from multiple nations is not possible.

Research objective three - broaden cross-cultural research beyond regional research. At present, much of the cross-cultural research emphasizes comparisons within regions (see, e.g., Table 5). The analysis indicates large scale comparisons between regions is limited with the majority positive correlations representing research in the tourism industry. Since 2010 with the emergence of the global economic crisis and with some noteworthy disasters, research focusing on factors affecting the tourism industry has received quite a bit of attention. For example, there have been large multi-nation studies emphasizing tourism and topics like social media use among tourists during crises (Schroeder \& Pennington-Gray, 2015; Schroeder, Pennington-Gray, Donohoe, \& Kiousis, 2013), sustainability in tourism across the EU (Bodosca, 2015), or factors that mitigate risk perception and crisis resistance among tourists (Hajibaba, et al., 2015).

The other primary vein of large-scale cross cultural research in crisis communication focuses on a few pan-European analyses. For example, explorations of food security and cross- 
national food contamination have emerged (Frewer et al., 2014; Lok \& Powell, 2000; Rutsaert et al., 2014; Verbeke, Viaene, \& Guiot, 1999), analyses of social media in crisis contexts (Moreno, Navarro, Tench, \& Zerfass, 2015; Rutsaert, et al., 2014; Vesnic-Alujevic, 2012 976), analyses of European-wide crisis management and practitioner applications (Stern, 1999; Tench \& Moreno, 2015; Verhoeven, Tench, Zerfass, Moreno, \& Verčič, 2014), and the European debt or financial crisis (Büchel, 2013; Robertson, 2014; Schmidt, 2014; Touri \& Rogers, 2013) have dominated pan-European cross-cultural comparisons.

This suggests that the opportunity to begin to build a more comprehensive understanding of ICC through multi-country cross-cultural comparisons is substantial. There are few limits in terms of concepts, industries, or comparative reactions to crises from any perspective as all need to be better developed in the context of crises. There are many ways that scholars can go about this data collection. One way is for a more meaningful engagement with our colleagues from other countries than just sharing ideas at conferences; instead, conference organizers could build in meaningful workshopping and collaboration sessions into the schedules to facilitate organizing multi-national studies. A second way is making more effective use of an increasingly global student and faculty by collecting more group data within our own departments with people from different countries recruiting participants from their home nations.

\section{Understanding Dominant Contexts in Current Research}

In building on the three broad research objectives that I have laid out, ICC research should also explore the particular contexts in which the most research is presently conducted and thus those areas that are most needed. I have taken two approaches to exploring this theme for ICC development. First, is to identify what research has emerged or dominated within particular regions and second to identify theory development and preference across regions as ways to assess the present state of research and identify new areas for research development. These regional research opportunities should be taken within the broad domain of any of the first three that I have discussed - broadening voices heard in ICC research, placing American research in context, and developing more meaningful cross-cultural comparisons.

To explore the dominant research themes in each region I analyzed the influence of time, fields journal articles were published in, and keywords and concepts explored using multiple hierarchical regression in order to identify the formative description of the ways that research in these regions differs from crisis research in the rest of the world. In addition, I also examined dominant theories used in crisis research within each of the regions using ANOVA and descriptive analysis. Across all geographic locations a strong central theme emerged - crisis communication research, particularly with regards to intercultural contexts, needs to broaden its theoretical, analytical, and publishing scope.

Broadening research about North America. The predominantly American-oriented research tradition in crisis communication is diverse; however, there are some aspects to crisis communication in North America to be considered (see Table 9). First, there is a significant under-representation of cultural or multi-cultural research compared to crisis research from the rest of the world. Second, American-oriented research predominantly publishes communication 
journals. In particular, crisis research from the American perspective is substantially under-represented in medical and health journals. By publishing disproportionally in a single field's journals, American-oriented research is not effectively disseminating the research to the fields and places that actually need it. Naturally, there is an inclination for scholars in schools and departments of communication to focus on communication journals, in an era where research impact is important, if we do not have diverse eyes on the research, it will have considerably less measurable impact. In addition, it creates a risk that American crisis researchers will also primarily use communication journals to build their understanding of crisis communication. While providing a strong background, focusing only on a communication journal perspective leads to an ethnocentric and limited understanding of crisis communication as these results demonstrate it preferences an American voice and set of perspectives further insulating American research from the global trends in ICC research. Finally, American-oriented research is more likely to focus on the communicative aspects of crisis communication compared to others it is significantly less likely to focus on industry and direct media analyses.

\section{Table 9}

\section{Regression for North American Crisis Communication Research}

\begin{tabular}{|c|c|c|c|c|c|c|c|c|c|}
\hline \multirow[b]{2}{*}{ Regressor } & \multicolumn{3}{|c|}{ Model 1} & \multicolumn{3}{|c|}{ Model 2} & \multicolumn{3}{|c|}{ Model 3} \\
\hline & Beta & SE & $t$ & Beta & SE & $t$ & Beta & SE & $t$ \\
\hline Intercept & & 3.31 & -6.38 & & 3.29 & 6.91 & & 3.28 & 6.55 \\
\hline Year & -.25 & .00 & $-6.38 * * *$ & -.25 & .00 & $-6.38 * * *$ & -.23 & .00 & $-5.89 * * *$ \\
\hline Medicine \& Health & & & & -.08 & .07 & $-1.91 *$ & -.09 & .07 & $-2.17^{*}$ \\
\hline Communication \& Language & & & & .07 & .04 & 1.88 & .07 & .04 & 1.76 \\
\hline Industries & & & & & & & -.06 & .04 & -1.52 \\
\hline Crisis Response & & & & & & & .06 & .04 & 1.56 \\
\hline Media Analysis & & & & & & & -.06 & .60 & -1.56 \\
\hline Culture/Multi-cultural & & & & & & & -.15 & .06 & $-3.96 * * *$ \\
\hline $\mathrm{F}$ & $40.74 * * *$ & & & $16.78 * * *$ & & & $11.19 * * *$ & & \\
\hline$\Delta F$ & 40.74 & & & 4.56 & & & 6.55 & & \\
\hline$R^{2}$ & .06 & & & .08 & & & .11 & & \\
\hline$R_{\text {adj }}^{2}$ & .06 & & & .07 & & & .10 & & \\
\hline$R^{2}$ change & .06 & & & .01 & & & .04 & & \\
\hline$d f$ & 1,617 & & & 2,615 & & & 4,611 & & \\
\hline
\end{tabular}

Notes. * Significant at .05 level; ${ }^{* * *}$ Significant at $p<.01$ level 
When we consider the role that theory plays in North American research (see Figure 1)a disproportionate amount of research is a-theoretical - a recurring theme across all regions. North American research uses six categories of theory most often - image-repair theory and situational crisis communication theory along with psychological, general public relations and communication, media, and crisis-specific theories.

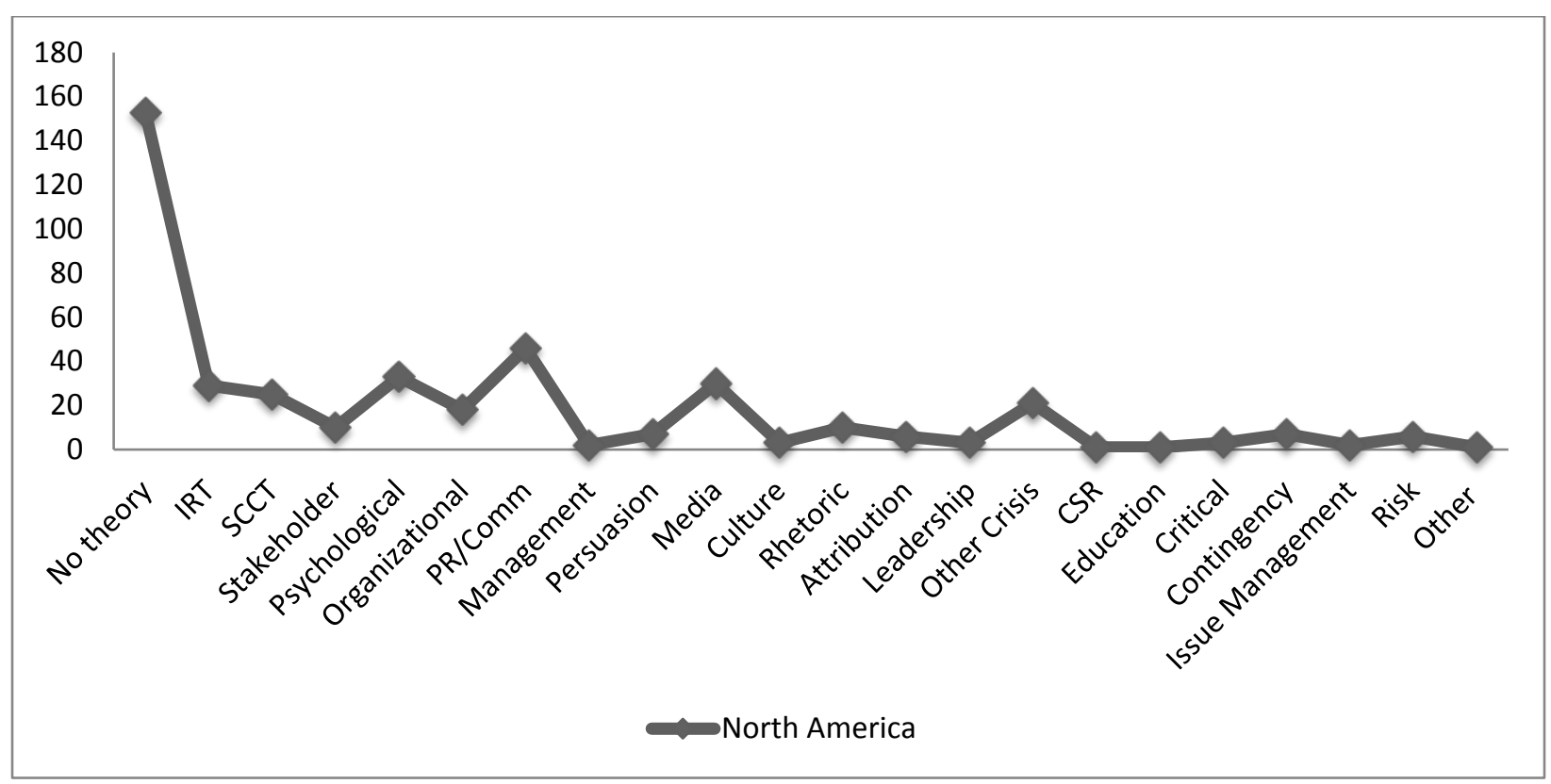

Figure 1. Theories used in North American-oriented crisis research

Therefore, there are three primary recommendations for North American-oriented crisis research. First, it must expand its consideration of cultural and multi-cultural research or it runs the risk of being less relevant in a global society. Second, scholars should disseminate their work more effectively by publishing more consistently across different fields of work. Finally, American-oriented research needs to consider a more diverse set of theoretical perspectives so that it does not pigeon-hole itself into a limited number of perspectives driving the regional research agenda.

Broadening research about Europe. Crisis communication focusing on Europe has been meaningfully growing over recent years - largely helped by the development of an active crisis research community within the last decade. This is good news as the field continues to develop and diversify. However, in understanding the key differences in European research compared to research in the rest of the world, there are a few important trends to acknowledge (see Table 10). First, Europeans are far less likely to publish in social science and humanities as well as communication journals. In part, this is likely because the field of communication is often combined with business schools in Europe and so there are more pressures to publish in business-oriented publications. Yet, whereas the American-oriented researchers needed to expand their focus beyond communication journals, to develop more credibility and impact 
within crisis communication, European-oriented researchers should work to publish more often in traditional communication journals. This is good for the field of crisis communication as it makes it more visible and diverse within the broader field of communication.

\section{Table 10}

\section{Regression for European Crisis Communication Research}

\begin{tabular}{|c|c|c|c|c|c|c|c|c|c|}
\hline \multirow[b]{2}{*}{ Regressor } & \multicolumn{3}{|c|}{ Model 1} & \multicolumn{3}{|c|}{ Model 2} & \multicolumn{3}{|c|}{ Model 3} \\
\hline & Beta & SE & $t$ & Beta & SE & $t$ & Beta & SE & $t$ \\
\hline Intercept & & 2.91 & -4.04 & & 2.91 & -3.84 & & 2.86 & -3.92 \\
\hline Year & .18 & .00 & $4.46 * * *$ & .17 & .00 & $4.32 * * *$ & .17 & .00 & $4.29 * * *$ \\
\hline Soc. Sci \& Humanities & & & & -.08 & .04 & -1.70 & -.07 & .04 & -1.50 \\
\hline Communicaton \& Language & & & & -.06 & .04 & -1.32 & -.05 & .04 & -1.17 \\
\hline Crisis Response & & & & & & & -.04 & .03 & -1.08 \\
\hline Relational Factors & & & & & & & -.07 & .07 & -.181 \\
\hline Media Analysis & & & & & & & .11 & .05 & $2.74 * *$ \\
\hline Training/Education & & & & & & & .08 & .11 & $2.03^{*}$ \\
\hline Culture/ Multi-cultural & & & & & & & .15 & .05 & $3.83 * * *$ \\
\hline Emotion & & & & & & & -.07 & .07 & $-1.85^{*}$ \\
\hline $\mathrm{F}$ & $19.86^{* * *}$ & & & $9.48 * * *$ & & & $7.84 * * *$ & & \\
\hline$\Delta F$ & 19.86 & & & 4.19 & & & 6.75 & & \\
\hline$R^{2}$ & .03 & & & .04 & & & .10 & & \\
\hline$R^{2}$ adj. & .03 & & & .04 & & & .09 & & \\
\hline$R^{2}$ change & .03 & & & .01 & & & .06 & & \\
\hline$d f$ & 1,617 & & & 2,615 & & & 6,609 & & \\
\hline
\end{tabular}


Additionally, European-oriented research is more likely to focus on three research areas - media analysis, training and education, and cultural research. It is also significantly less likely to examine crisis response, relational factors influencing (or influenced by) crises, and emotion. As such, it would appear that English language European-oriented research does not focus on the process of crisis communication as directly as other research focusing on other regions. Theoretically, while some meaningful use of image repair, situational crisis communication, psychological, organizational, critical, and other crisis-related theories exists in Europeanoriented scholarship, the predominant theoretical perspective employed emphasizes mediabased theory (see Figure 2). This suggests that much of the English-language European-oriented research is likely either practitioner-oriented or emphasizes rhetorical case studies such as analyses of communication management competences in European public relations firms (Tench \& Moreno, 2015), the case of the Muhammad cartoons in Denmark (Lindholm \& Olsson, 2010), or the case of Findus Nordic and the horsemeat scandal (Falkheimer \& Heide, 2015).

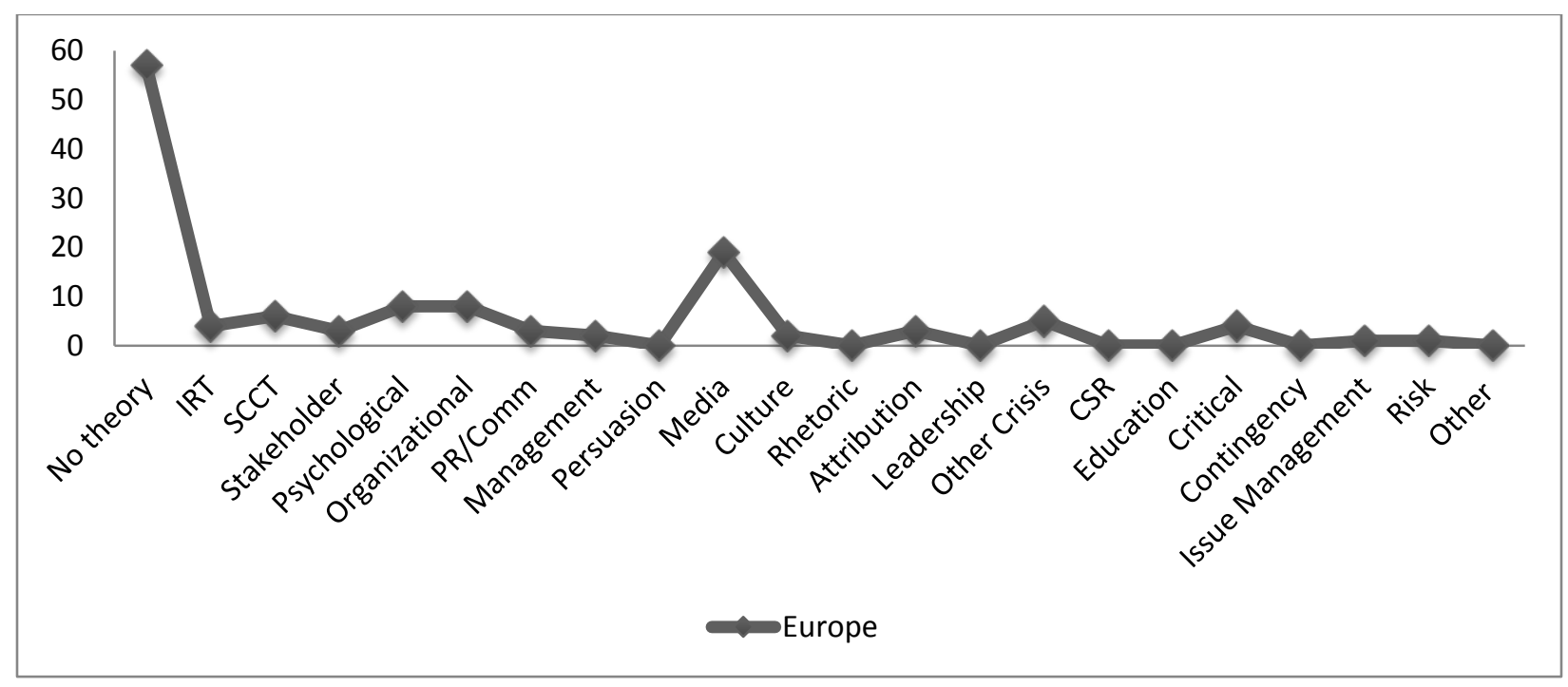

Figure 2. Theories used in European-oriented crisis research

While the emergence of an active research community in Europe is important, and European-oriented research is more likely to emphasize culture or multi-cultural dimensions, there are two primary suggestions for research in this region. First, European-oriented research needs to begin focusing more on messages and relative message effects instead of mediaoriented research. There is a wealth of cross-cultural information and understanding to be developed about the impact of crises on all stakeholder groups, their attitudes towards the organizations, and certainly their attitudes towards issues that is largely untapped. Second, similarly, European-oriented research needs to consider more theoretical perspectives so that it broadens its conceptualization of ICC research. 
Broadening research about the rest of the world. Because of the fundamental dearth of research on other regions around the world, any and all research embracing different perspectives and exploring the dual forces of culture and crisis on people and organizations needs to be developed. It is difficult to draw many conclusions about the other regions because of the small amount of research available compared to Europe and especially North America. However, there a couple of salient points about research in other parts of the world. First, in most regions (see Tables 11, 12, 13, 14, and 15 - note there were no significant findings for Africa) there is already a strong emphasis on issues related to culture. That certainly needs to continue to be developed and developed in regions like Africa and Australasia where that might not be the case. Second, when we take a look at the theoretical orientations of research across the world (see Figure 3), we can see an emphasis - to some degree - on image repair and situational crisis communication theories but also influences of stakeholder, psychological, organizational, PR/communication, attribution, media, other crisis, and critical theories. It seems as though there is greater theoretical diversity in the research occurring across the globe. Continuing to develop theoretically diverse perspectives, in an ICC agenda, is important to maximize different voices and perspectives articulated about crisis.

\section{Table 11}

Regression for Central \& South America, Caribbean Crisis Communication Research

\begin{tabular}{|c|c|c|c|c|c|c|}
\hline \multirow[b]{2}{*}{ Regressor } & \multicolumn{3}{|c|}{ Model 1} & \multicolumn{3}{|c|}{ Model 2} \\
\hline & Beta & $\mathrm{SE}$ & $t$ & Beta & SE & $t$ \\
\hline Intercept & & .02 & 69.90 & & .04 & 18.82 \\
\hline Industry Specific Jnls & .09 & .01 & $2.12 *$ & .05 & .01 & 1.19 \\
\hline Issue Management & & & & .14 & .02 & $3.62 * * *$ \\
\hline Culture/Multi-cultural & & & & .22 & .01 & $5.52 * * *$ \\
\hline Demographics & & & & .06 & .03 & 1.58 \\
\hline Risk & & & & .07 & .02 & 1.70 \\
\hline Social Media & & & & .08 & .01 & $2.14^{*}$ \\
\hline $\mathrm{F}$ & $4.49 *$ & & & $10.73^{* * *}$ & & \\
\hline$\Delta F$ & 4.49 & & & 11.90 & & \\
\hline$R^{2}$ & .01 & & & .10 & & \\
\hline$R^{2}{ }_{a d j}$ & .01 & & & .09 & & \\
\hline$R^{2}$ change & .01 & & & .09 & & \\
\hline$d f$ & 1,617 & & & 5,612 & & \\
\hline
\end{tabular}

Notes. ${ }^{*}$ Significant at .05 level; ${ }^{* * *}$ Significant at $p<.01$ level 
Table 12

Regression for Asia (East) Crisis Communication Research

\begin{tabular}{|c|c|c|c|}
\hline \multirow[b]{2}{*}{ Regressor } & \multicolumn{3}{|c|}{ Model 1} \\
\hline & Beta & $\mathrm{SE}$ & $t$ \\
\hline Intercept & & .07 & 10.47 \\
\hline Culture/ Multi-cultural & .25 & .03 & $6.34 * * *$ \\
\hline CSR & .09 & .05 & $2.26^{*}$ \\
\hline $\mathrm{F}$ & $22.81 * * *$ & & \\
\hline$\Delta F$ & 22.81 & & \\
\hline$R^{2}$ & .07 & & \\
\hline$R_{\text {adj }}^{2}$ & .07 & & \\
\hline$R^{2}$ change & .07 & & \\
\hline$d f$ & 2,619 & & \\
\hline
\end{tabular}

Notes. ${ }^{*}$ Significant at .05 level; ${ }^{* * *}$ Significant at $p<.01$ level

Table 13

Regression for Australasian Crisis Communication Research

\begin{tabular}{|c|c|c|c|c|c|c|}
\hline \multirow[b]{2}{*}{ Regressor } & \multicolumn{3}{|c|}{ Model 1} & \multicolumn{3}{|c|}{ Model 2} \\
\hline & Beta & SE & $t$ & Beta & SE & $t$ \\
\hline Intercept & & .04 & 24.78 & & .05 & 17.75 \\
\hline Medicine \& Health & .06 & .03 & 1.34 & .07 & .03 & 1.57 \\
\hline Industry-Specific Jnls & .11 & .03 & $2.71^{* *}$ & .08 & .03 & $1.91 *$ \\
\hline Industry & & & & .09 & .02 & $2.29 *$ \\
\hline Risk & & & & .05 & .03 & 1.18 \\
\hline $\mathrm{F}$ & $6.18 * *$ & & & $4.70 * * *$ & & \\
\hline$\Delta F$ & 6.18 & & & 3.17 & & \\
\hline$R^{2}$ & .02 & & & .03 & & \\
\hline$R^{2}{ }_{a d j}$ & .02 & & & .03 & & \\
\hline$R^{2}$ change & .02 & & & .01 & & \\
\hline$d f$ & 2,616 & & & 2,614 & & \\
\hline
\end{tabular}

Table 14

Regression for Middle Eastern Crisis Communication Research

\begin{tabular}{lrrr}
\hline & \multicolumn{4}{c}{ Model 1} \\
Regressor & Beta & SE & \multicolumn{1}{c}{$t$} \\
\hline Intercept & & .04 & 21.00 \\
Training/Education & .11 & .03 & $2.74^{* *}$ \\
Culture/ Multi-cultural & .12 & .01 & $3.03^{* *}$ \\
Demographics & .08 & .03 & $1.89^{*}$ \\
$\mathrm{~F}$ & & & \\
$\Delta F$ & $7.11^{* * *}$ & & \\
$R^{2}$ & 7.11 & & \\
$R^{2}$ adj. & .03 & & \\
$R^{2}$ change & .03 & & \\
$d f$ & .03 & & \\
\hline
\end{tabular}

Notes. ${ }^{*}$ Significant at .05 level; ${ }^{* *}$ Significant at .01 level; ${ }^{* * *}$ Significant at $p<.01$ level 
Table 15

Regression for Asian (South/Southeastern) Crisis Communication Research

\begin{tabular}{|c|c|c|c|}
\hline \multirow[b]{2}{*}{ Regressor } & \multicolumn{3}{|c|}{ Model 1} \\
\hline & Beta & SE & $t$ \\
\hline Intercept & & .11 & 8.16 \\
\hline Industry & .07 & .04 & 1.75 \\
\hline Issue Management & -.01 & .09 & -.23 \\
\hline Culture/ Multi-cultural & .16 & .05 & $4.12 * * *$ \\
\hline $\mathrm{F}$ & 6.76 & & \\
\hline$\Delta F$ & 6.76 & & \\
\hline$R^{2}$ & .03 & & \\
\hline$R_{a d j}^{2}$ & .03 & & \\
\hline$R^{2}$ change & .03 & & \\
\hline$d f$ & 3,618 & & \\
\hline
\end{tabular}

Notes. $* * *$ Significant at $p<.01$ level

Broadening the use of theory. In 2011 at the Crisis2 conference in Denmark the keynote speaker made an unpopular statement - that he did not believe there was enough theory in crisis communication. And then in a practitioner/academic discussion in 2016 at the International Crisis and Risk Communication Conference in the US, practitioners asked why there was not more predictive theory that would help them build strategy and the academics responding to the question did not have a good answer. I would partly agree with these assessments because while it is evident that crisis communication has a diverse range of applicable theoretical perspectives at its disposal (see Table 4), academics and practitioners publishing in crisis communication often fail to use them (see Figures 1, 2, 3, and 4). Worse yet, when we do there is often an assumption that image repair theory and situational crisis communication theory are the dominant theories in the field (Ha \& Boynton, 2014; Kim \& Sung, 2014; Xu \& Li, 2013), when most of these assumptions are based in a limited understanding of the full field of research in crisis communication.

Clearly, as the systematic review demonstrates, not only are there rich theoretical traditions connected to crisis communication - ranging across the spectrum of perspectives but also the field is not dominated by just a couple of theories. Now, we should be applying a diverse set of theories across a diverse set of circumstances. Specifically, if we are going to meet practitioners' calls for more predictive theories, we need to be focusing more often on stakeholder perspectives instead of describing the nature of crisis response. Herein lays the need for strong ICC theory development. Given that there is already substantial interest in considering global issues (Gurman \& Ellenberger, 2015; Lawniczak, 2009; Pang, Cropp, \& Cameron, 2006; Taneja, Pryor, Sewell, \& Recuero, 2014), social media (Bruns \& Stieglitz, 2013; Brynielsson, Johansson, Jonsson, \& Westling, 2014; Coombs \& Holladay, 2014; Diers \& Donohue, 2013; Fraustino \& Ma, 2015; Gu, 2014; Mou \& Lin, 2014; Sanderson \& Emmons, 2014; Sung \& Hwang, 2014; Yin, Feng, \& Wang, 2015), and disasters (Chae et al., 2014; Figueroa, 2013 2902; Gesser-Edelsburg, Shir-Raz, Hayek, \& Lev, 2015; Liu, Fraustino, \& Jin, 2015; Sutton, League, Sellnow, \& Sellnow, 2015; Verroen, Gutteling, \& Vries, 2013) as emergent and meaningful areas of crisis research that need an intercultural perspective, emphasizing 
more culture-related concepts and cultural theories is a natural progression in our understanding of crisis communication.

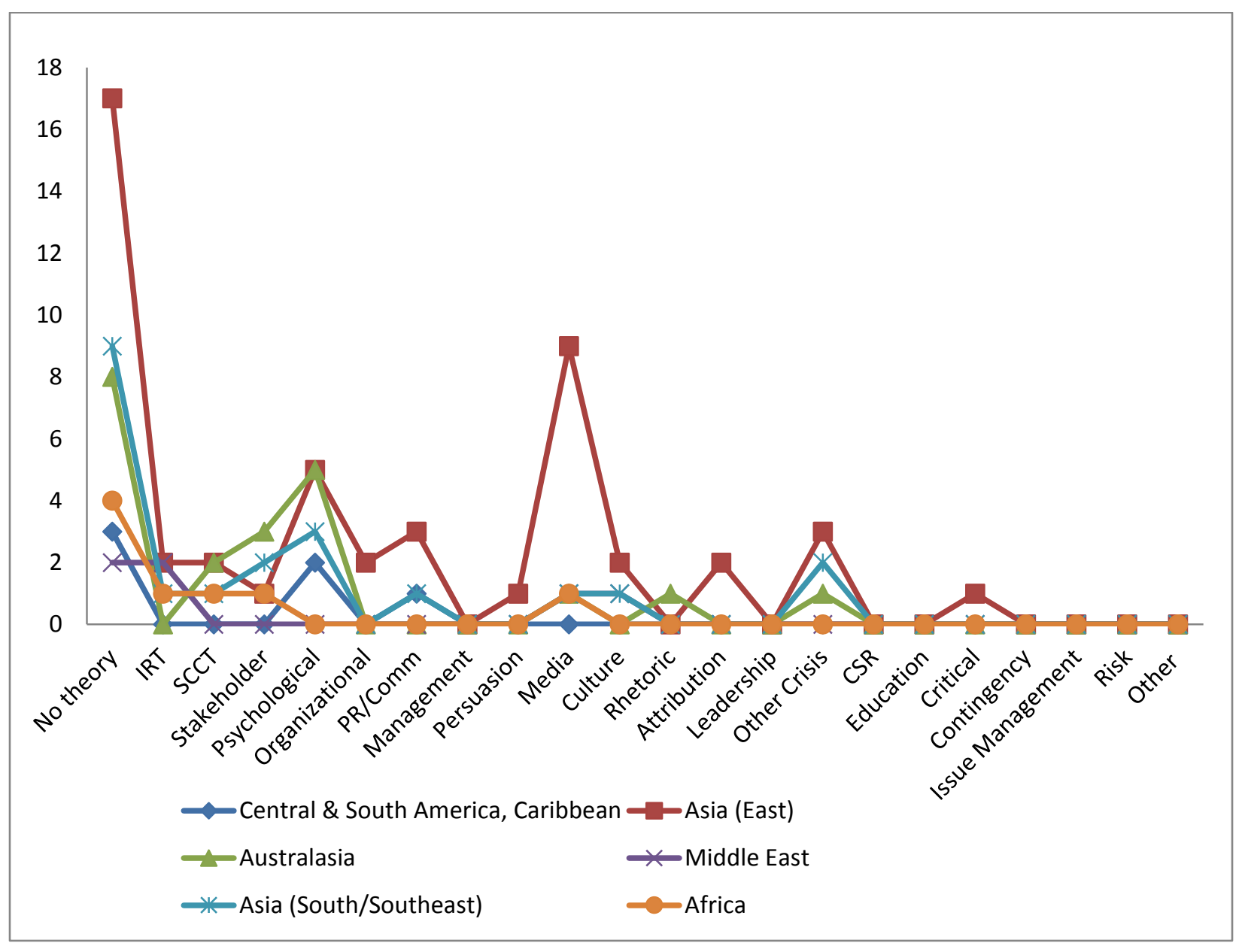

Figure 3. Theories used in crisis research across regions.

\section{Looking Ahead}

My primary goal in this systematic review of crisis communication literature was to offer some evidence-based arguments for an intercultural crisis communication research agenda by shining a light on both the centrality of cultural knowledge for crisis communication and the lack of research and theory building in this area. I do believe that modern crisis communication research is becoming more multi-cultural and exploring more voices and perspectives with an active research community that is globally minded. However, I also believe that we need to work more closely with cultural scholars and use stronger culturally-based resources in our analyses. Therefore, I have suggested three broad research objectives - broadening voices heard in ICC research, placing American research in context, and developing more meaningful cross-cultural comparisons. In addition, in identifying these broad research objectives, I have also provided suggestions throughout as to how researchers could begin. These suggestions are certainly not all-inclusive; rather, they are meant to provide some initial ideas and directions for researchers interested in developing their own crisis communication research agenda to tailor 
it to their particular interests. In so doing, I believe we can develop research within and across regions in a number of different ways, ranging from simply cultivating more knowledge about the Americas (outside of North America), Asia, Africa, Australasia, and the Middle East to more careful considerations of where we publish in North America and Europe, developing underserved areas of research, and broadening our theoretical perspectives.

\section{References}

An, S.-K., Park, D.-J., Cho, S., \& Berger, B. (2010). A cross-cultural study of effective organizational crisis response strategy in the United States and South Korea. International Journal of Strategic Communication, 4(4), 225-243.

Bodosca, S. L. (2015). Sustainable decision making under the crisis for tourism businesses: a survey of the literature for EU Member States. Ecoforum Journal, 4.

Bruns, A., \& Stieglitz, S. (2013). Towards more systematic Twitter analysis: Metrics for tweeting activities. International journal of social research methodology, 16(2), 91-108.

Brynielsson, J., Johansson, F., Jonsson, C., \& Westling, A. (2014). Emotion classification of social media posts for estimating people's reactions to communicated alert messages during crises. Security Informatics, 3(1), 1-11. doi: 10.1186/s13388-014-0007-3

Büchel, K. (2013). Do words matter? The impact of communication on the PIIGS'CDS and bond yield spreads during Europe's sovereign debt crisis. European Journal of Political Economy, 32, 412-431. doi: 10.1016/j.ejpoleco.2013.08.004

Chae, J., Thom, D., Jang, Y., Kim, S., Ertl, T., \& Ebert, D. S. (2014). Public behavior response analysis in disaster events utilizing visual analytics of microblog data. Computers \& Graphics, 38, 51-60. doi: http://dx.doi.org/10.1016/j.cag.2013.10.008

Coombs, T. W., \& Holladay, S. J. (2014). How publics react to crisis communication efforts: Comparing crisis response reactions across sub-arenas. Journal of Communication Management, 18(1), 40-57.

de Fatima Oliveira, M. (2013). Multicultural environments and their challenges to crisis communication. Journal of Business Communication, 0021943613487070. doi: 10.1177/0021943613487070

Derrickson, J. P., \& Brown, A. C. (2002). Food security stakeholders in Hawai'i: Perceptions of food security monitoring. Journal of Nutrition Education, 34(2), 72-84.

Diers, A. R., \& Donohue, J. (2013). Synchronizing crisis responses after a transgression: An analysis of BP's enacted crisis response to the Deepwater Horizon crisis in 2010. Journal of Communication Management, 17(3), 252-269.

Falkheimer, J., \& Heide, M. (2015). Trust and Brand Recovery Campaigns in Crisis: Findus Nordic and the Horsemeat Scandal. International Journal of Strategic Communication, 9(2), 134-147. doi: 10.1080/1553118X.2015.1008636

Figueroa, P. M. (2013). Risk communication surrounding the Fukushima nuclear disaster: an anthropological approach. Asia Europe Journal, 11(1), 53-64.

Fraustino, J. D., \& Ma, L. (2015). CDC's Use of Social Media and Humor in a Risk Campaign"Preparedness 101: Zombie Apocalypse". Journal of Applied Communication Research, 43(2), 222-241. doi: 10.1080/00909882.2015.1019544 
Frewer, L., Fischer, A., Brennan, M., Bánáti, D., Lion, R., Meertens, R., . . Vereijken, C. (2014). Risk/benefit communication about food-a systematic review of the literature. Critical reviews in food science and nutrition, 56(10), 1728-1745. doi:

10.1080/10408398.2013.801337

Gesser-Edelsburg, A., Shir-Raz, Y., Hayek, S., \& Lev, O. S.-B. (2015). What does the public know about Ebola? The public's risk perceptions regarding the current Ebola outbreak in an as-yet unaffected country. American journal of infection control, 43(7), 669-675. doi: http://dx.doi.org/10.1016/j.ajic.2015.03.005

Goby, V. P., \& Nickerson, C. (2015). The impact of culture on the construal of organizational crisis: perceptions of crisis in Dubai. Corporate Communications: An International Journal, 20(3), 310-325.

Gonzales-Herrero, A., \& Pratt, C. B. (1998). Marketing crises in tourism: Communication strategies in the United States and Spain. Public Relations Review, 24(1), 83-97.

Gu, Q. (2014). Sina Weibo: A mutual communication apparatus between the Chinese government and Chinese citizens. China Media Research, 10(2), 72-86.

Gurman, T. A., \& Ellenberger, N. (2015). Reaching the global community during disasters: findings from a content analysis of the organizational use of Twitter after the 2010 Haiti earthquake. Journal of Health Communication, 20(6), 687-696. doi: 10.1080/10810730.2015.1018566

Ha, J. H., \& Boynton, L. (2014). Has crisis communication been studied using an interdisciplinary approach? A 20-year content analysis of communication journals. International Journal of Strategic Communication, 8(1), 29-44. doi: 10.1080/1553118X.2013.850694

Hajibaba, H., Gretzel, U., Leisch, F., \& Dolnicar, S. (2015). Crisis-resistant tourists. Annals of Tourism Research, 53, 46-60. doi: 10.1016/j.annals.2015.04.001

Haruta, A., \& Hallahan, K. (2003). Cultural issues in airline crisis communications: A Japan-US comparative study. Asia Journal of Communication, 13(2), 122-150.

Jindal, S., Laveena, L., \& Aggarwal, A. (2015). A Comparitive Study Of Crisis Management-Toyota V/S General Motors. Scholedge International Journal of Management \& Development 2(6), 1-12.

Kim, S.-Y., Choi, M.-I., Reber, B. H., \& Kim, D. (2014). Tracking public relations scholarship trends: Using semantic network analysis on PR Journals from 1975 to 2011. Public Relations Review, 40(1), 116-118. doi: http://dx.doi.org/10.1016/j.pubrev.2013.11.017

Kim, S., \& Sung, K. H. (2014). Revisiting the effectiveness of base crisis response strategies in comparison of reputation management crisis responses. Journal of Public Relations Research, 26(1), 62-78. doi: 10.1080/1062726X.2013.795867

Koc, E. (2013). Power distance and its implications for upward communication and empowerment: Crisis management and recovery in hospitality services. The International Journal of Human Resource Management, 24(19), 3681-3696.

Lawniczak, R. (2009). Re-examining the economic roots of public relations. Public Relations Review, 35(4), 346-352. doi: 10.1016/j.bbr.2011.03.031

Lindholm, K., \& Olsson, E.-K. (2010). Crisis communication as a multilevel game: The Muhammad cartoons from a crisis diplomacy perspective. The International Journal of Press/Politics, 16(2), 254-271. 
Liu, B. F., Fraustino, J. D., \& Jin, Y. (2015). How Disaster Information Form, Source, Type, and Prior Disaster Exposure Affect Public Outcomes: Jumping on the Social Media Bandwagon? Journal of Applied Communication Research, 43(1), 44-65. doi: 10.1080/00909882.2014.982685

Lok, C., \& Powell, D. (2000). The Belgian Dioxin Crisis of the Summer of 1999: a case study in crisis communications and management Guelph: University of Guelph.

Moreno, A., Navarro, C., Tench, R., \& Zerfass, A. (2015). Does social media usage matter? An analysis of online practices and digital media perceptions of communication practitioners in Europe. Public Relations Review, 41(2), 242-253. doi: 10.1016/j.pubrev.2014.12.006

Mou, Y., \& Lin, C. A. (2014). Communicating Food Safety via the Social Media The Role of Knowledge and Emotions on Risk Perception and Prevention. Science Communication, 36(5), 593-616. doi: 10.1177/1075547014549480

Olofsson, A. (2007). Crisis communication in multicultural societies: A study of municipalities in Sweden. International Journal of Mass Emergencies and Disasters, 25(2), 145-172.

Palmer-Silveira, J. C., \& Ruiz-Garrido, M. F. (2014). Examining US and Spanish Annual Reports Crisis Communication. Business and Professional Communication Quarterly, 1-17. doi: $10.1177 / 2329490614543176$

Pang, A., Cropp, F., \& Cameron, G. T. (2006). Corporate crisis planning: Tensions, issues, and contradictions. Journal of Communication Management, 10(4), 371-389.

Robertson, A. (2014). Atlas reports: Global television constructions of economic crisis. European Journal of Communication, 1-8. doi: 10.1177/0267323114535884

Rutsaert, P., Pieniak, Z., Regan, Á., McConnon, Á., Kuttschreuter, M., Lores, M., . . Verbeke, W. (2014). Social media as a useful tool in food risk and benefit communication? A strategic orientation approach. Food policy, 46, 84-93. doi: http://dx.doi.org/10.1016/j.foodpol.2014.02.003

Sanderson, J., \& Emmons, B. (2014). Extending and Withholding Forgiveness to Josh Hamilton Exploring Forgiveness Within Parasocial Interaction. Communication \& Sport, 2(1), 2447. doi: $10.1177 / 2167479513482306$

Schmidt, V. A. (2014). Speaking to the markets or to the people? A discursive institutionalist analysis of the EU's sovereign debt crisis. The British Journal of Politics and International Relations, 16(1), 188-209. doi: 10.1111/1467-856X.12023

Schroeder, A., \& Pennington-Gray, L. (2015). The role of social media in international tourist's decision making. Journal of Travel Research, 54(5), 584-595. doi: 10.1177/0047287514528284

Schroeder, A., Pennington-Gray, L., Donohoe, H., \& Kiousis, S. (2013). Using social media in times of crisis. Journal of Travel \& Tourism Marketing, 30(1-2), 126-143. doi: 10.1080/10548408.2013.751271

Stern, E. K. (1999). Crisis decisionmaking: A cognitive institutional approach, 6

Sung, M., \& Hwang, J.-S. (2014). Who drives a crisis? The diffusion of an issue through social networks. Computers in Human Behavior, 36, 246-257. doi: http://dx.doi.org/10.1016/j.chb.2014.03.063 
Sutton, J., League, C., Sellnow, T. L., \& Sellnow, D. D. (2015). Terse messaging and public health in the midst of natural disasters: The case of the Boulder floods. Health communication, 30(2), 135-143. doi: 10.1080/10410236.2014.974124

Taneja, S., Pryor, M. G., Sewell, S., \& Recuero, A. M. (2014). Strategic Crisis Management: A Basis for Renewal and Crisis Prevention. Journal of Management Policy and Practice, 15(1), 78.

Taylor, M. (2000). Cultural variance as a challenge to global public relations: A case study of the Coca-Cola scare in Europe. Public Relations Review, 26(3), 277-293.

Tench, R., \& Moreno, A. (2015). Mapping communication management competencies for European practitioners: ECOPSI an EU study. Journal of Communication Management, 19(1), 39-61. doi: http://dx.doi.org/10.1108/JCOM-11-2013-0078

Touri, M., \& Rogers, S. L. (2013). Europe's Communication Deficit and the UK Press: Framing the Greek Financial Crisis. Journal of Contemporary European Studies, 21(2), 175-189. doi: 10.1080/14782804.2013.815462

Verbeke, W., Viaene, J., \& Guiot, O. (1999). Health communication and consumer behavior on meat in Belgium: from BSE until dioxin. Journal of Health Communication, 4(4), 345-357.

Verhoeven, P., Tench, R., Zerfass, A., Moreno, A., \& Verčič, D. (2014). Crisis? What crisis?. How European professionals handle crises and crisis communication. Public Relations Review, 40(1), 107-109. doi: 10.1016/j.pubrev.2013.10.010

Verroen, S., Gutteling, J. M., \& Vries, P. W. (2013). Enhancing Self-Protective Behavior: Efficacy Beliefs and Peer Feedback in Risk Communication. Risk Analysis, 33(7), 1252-1264. doi: 10.1111/j.1539-6924.2012.01924.x

Vesnic-Alujevic, L. (2012). Political participation and web 2.0 in Europe: A case study of Facebook. Public Relations Review, 38, 466-470. doi: 10.1016/j.pubrev.2012.01.010

$\mathrm{Xu}, \mathrm{K} .$, \& Li, W. (2013). An ethical stakeholder approach to crisis communication: A case study of Foxconn's 2010 employee suicide crisis. Journal of Business Ethics, 117(2), 371-386. doi: 10.1007/s10551-012-1522-0

Yin, J., Feng, J., \& Wang, Y. (2015). Social Media and Multinational Corporations' Corporate Social Responsibility in China: The Case of ConocoPhillips Oil Spill Incident. IEEE Transactions on Professional Communication, 58(2), 135-153. doi: 10.1109/TPC.2015.2433071

Zhao, Y. (2014). Communication, Crisis, \& Global Power Shifts: An Introduction. International Journal of Communication, 8, 26. 


\section{Appendix A: Full List of Sources Analyzed in Systematic Review of Literature}

Aalbert, T., van Aelst, P., \& Curran, J. (2010). Media systems and the political information environment: A cross-national comparison. International Journal of Press and Politics, 15(3), 255-271.

Adams, T. M., \& Stewart, L. D. (2015). Chaos theory and organizational crisis: A theoretical analysis of the challenges faced by the New Orleans Police Department during Hurricane Katrina. Public Organization Review, 15(3), 415-431. doi:10.1007/s11115-014-0284-9

Ahluwalia, R., Burnkrant, R. E., \& Unnava, H. R. (2000). Consumer response to negative publicity: The moderating role of commitment. Journal of Marketing Research, 37(2), 203-214. doi:http://dx.doi.org/10.1509/jmkr.37.2.203.18734

Albu, O. B., \& Wehmeier, S. (2014). Organizational transparency and sense-making: The case of Northern Rock. Journal of Public Relations Research, 26(2), 117-133. doi:10.1080/1062726X.2013.795869

Alder, G. (1997). Managing environmental uncertainty with legitimate authority: A comparative analysis of the... . Journal of Applied Communication Research, 25(2), 98-115.

Aldoory, L., Kim, J.-N., \& Tindall, N. (2010). The influence of perceived shared risk in crisis communication: Elaborating the situational theory of publics. Public Relations Review, 36(2), 134-140.

Allan, S., \& Peters, C. (2015). Visual truths of citizen reportage: Four research problematics. Information, Communication \& Society, 18(11), 1348-1361. doi:10.1080/1369118X.2015.1061576

Allen, M. W., \& Caillouet, R. H. (1994). Legitimation endeavors: Impression management strategies used by an organization in crisis. Communication Monographs, 61, 44-64.

Alpaslan, C., S, G., \& Mitroff, I. (2009). Corporate Governance in the Context of Crises: Towards a Stakeholder Theory of Crisis Management. Journal of Contingencies \& Crisis Management, 17(1), 38-49.

An, S.-K., \& Gower, K. K. (2009). How do the news media frame crises? A content analysis of crisis news coverage. Public Relations Review, 35 , 107-112.

An, S.-K., Park, D.-J., Cho, S., \& Berger, B. (2010). A cross-cultural study of effective organizational crisis response strategy in the United States and South Korea. International Journal of Strategic Communication, 4(4), 225-243.

Anderson, B., Swenson, R., \& Kinsella, J. (2014). Responding in real time: Creating a social media crisis simulator for the classroom. Communication Teacher, 28(2), 85-95. doi:10.1080/17404622.2013.865766

Anderson, C., \& Bieniaszewska, R. (2005). The role of corporate social responsibility in an oil company's expansion into new territories. Corporate Social Responsibility and Environmental Management, 12(1), 1-9. doi:820596451

Anderson, W. A. (1969). Disaster warning and communication processes in two communities. Journal of Communication, 19(2), 92-104.

Andsager, J., \& Smiley, L. (1998). Evaluating the public information: Shaping news coverage of the silicone implant controversy. Public Relations Review, 24(2), 183-201.

Antonacopoulou, E. P., \& Sheaffer, Z. (2014). Learning in Crisis Rethinking the Relationship Between Organizational Learning and Crisis Management. Journal of Management Inquiry, 23(1), 5-21. doi:10.1177/1056492612472730

Argenti, P. (2002). Crisis communication: Lessons from 9/11. Harvard Business Review, 103-109.

Armenakis, A. A., \& Fredenberger, W. B. (1995). Process strategies for turnaround change agents: Crisis and non-crisis situations. Strategic Change, 4(1), 19-31.

Arpan, L. M. (2002). When in Rome? The effects of spokesperson ethnicity on audience evaluation of crisis communication. The Journal of Business Communication, 39(3), 314-339.

Austin, L., \& Jin, Y. (2015). Approaching Ethical Crisis Communication with Accuracy and Sensitivity: Exploring Common Ground and Gaps between Journalism and Public Relations. Public Relations Journal, 9(1), 2.

Austin, L. L., Liu, B. F., \& Jin, Y. (2014). Examining signs of recovery: How senior crisis communicators define organizational crisis recovery. Public Relations Review, 40(5), 844-846. doi:http://dx.doi.org/10.1016/j.pubrev.2014.06.003

Avery, E., Lariscy, R. and Kim, S. and Hocke, T. (2010). A quantitative review of crisis communication research in public

relations from 1991 to 2009. Public Relations Review, 36(2), 190-192. doi:10.1016/j.pubrev.2010.01.001

Avery, E. J., \& Kim, S. (2009). Anticipating or precipitating crisis? Health agencies may not be heeding best practice advice in avian flu press releases. Journal of Public Relations Research, 21(2), 187-197.

Avraham, E. (2013). Crisis communication, image restoration, and battling stereotypes of terror and wars: Media strategies for attracting tourism to Middle Eastern countries. American Behavioral Scientist, 0002764213487733. doi:10.1177/0002764213487733

Avraham, E. (2015). Destination image repair during crisis: Attracting tourism during the Arab Spring uprisings. Tourism management, 47, 224232.

Baden, C., \& Springer, N. (2014). Com(ple)menting the news on the financial crisis: The contribution of news users' commentary to the diversity of viewpoints in the public debate. European Journal of Communication, 29(5), 529-548. doi:10.1177/0267323114538724

Balmer, J. M., Blombäck, A., \& Scandelius, C. (2013). Corporate heritage in CSR communication: a means to responsible brand image? Corporate Communications: An International Journal, 18(3), 362-382. doi:http://dx.doi.org/10.1108/CCIJ-07-2012-0048

Barnett, C. K., \& Pratt, M. G. (2000). From threat-rigidity to flexibility-Toward a learning model of autogenic crisis in organizations. Journal of Organizational Change Management, 13(1), 74-88.

Barrett, M. S. (2005). Spokespersons and message control: How the CDC lost credibility during the Anthrax Crisis. Qualitative Research Reports in Communication, 6(1), 59-68.

Barton, L. (1990). Crisis management: Selecting communications strategy. Management decision, 28(6).

Barton, L. (1994). Preparing the marketing manager for crisis: the use and application of new strategic tools. Marketing Intelligence \& Planning, 12(11), 41-46.

Basham, C. (2001). Crisis communication at Southern California Edison: Dealing with deregulation. Strategic Communication Management, 1417.

Baucus, M. S., \& Baucus, D. A. (1997). Paying the piper: an empirical examination of longer-term financial consequences of illegal corporate behavior. Academy of Management Journal, 40(1), 129-152.

Diers-Lawson, A. (2017). A state of emergency in crisis communication: An intercultural crisis communication research agenda. Journal of Intercultural Communication Research, 46(1). DOI:10.1080/17475759.2016.1262891. 
Bauman, D. C. (2011). Evaluating ethical approaches to crisis leadership: insights from unintentional harm research. Journal of Business Ethics, 98(2), 281-295. doi:http://dx.doi.org/10.1007/s10551-010-0549-3

Bean, H., Sutton, J., Liu, B. F., Madden, S., Wood, M. M., \& Mileti, D. S. (2015). The study of mobile public warning messages: A research review and agenda. Review of Communication, 15(1), 60-80. doi:10.1080/15358593.2015.1014402

Beck, E., \& Mileti, D. (1975). Communication in Crisis. Communication Research, 2(1), 24-49.

Bell, L. M. (2010). Crisis communication: The praxis of response. Review of Communication, 10(2), 142-155.

Bennett, R., \& Kottasz, R. (2000). Practitioner perceptions of corporate reputation: an empirical investigation. Corporate Communications: An International Journal, 5(4), 224-235.

Benoit, W. L. (1995). Sears' repair of its auto service image: Image restoration discourse in the corporate sector. Communication Studies, 46(12), 89-105.

Benoit, W. L. (1997). Hugh Grant's image restoration discourse: An actor apologizes. Communication Quarterly, 45(3), $251-267$.

Benoit, W. L. (1997). Image repair discourse and crisis communication. Public Relations Review, 23(2), $177-187$.

Benoit, W. L., \& Czerwinski, A. (1997). A critical analysis of USAir's image repair discourse. Business Communication Quarterly, 60(3), 38-57.

Benoit, W. L., \& Henson, J. R. (2009). President Bush's image repair discourse on Hurricane Katrina. Public Relations Review, $35,40-46$.

Benson, J. A. (1988). Crisis revisited: An analysis of strategies used by Tylenol in the second tampering episode. Communication Studies, 39(1), 49-66.

Berger, D. (2009). Constructing crime, framing disaster: Routines of criminalization and crisis in Hurricane Katrina. Punishment and Society, 11(4), 491-510.

Berlin, J. M., \& Carlström, E. D. (2015). Collaboration exercises: What do they contribute? Journal of Contingencies and Crisis Management, 23(1), 11-23. doi:10.1111/1468-5973.12064

Blackman, D., \& Ritchie, B. W. (2008). Tourism crisis management and organizational learning: The role of reflection in developing effective DMO crisis strategies. Journal of Travel \& Tourism Marketing, 23(2-4), 45-57.

Blaney, J. R., Benoit, W. L., \& Brazeal, L. M. (2002). Blowout!: Firestone's image restoration campaign. Public Relations Review, 28(4), 379-392.

Bodosca, S. L. (2015). Sustainable decision making under the crisis for tourism businesses: a survey of the literature for EU Member States. Ecoforum Journal, 4.

Boin, A., \& Hart, P. (2003). Public leadership in times of crisis: Mission impossible? . Public Administration Review, 63(5), $544-553$.

Boin, A., Kuipers, S., \& Overdijk, W. (2013). Leadership in times of crisis: a framework for assessment. International Review of Public Administration, 18(1), 79-91.

Boin, A., 't Hart, P., \& McConnell, A. (2009). Crisis exploitation: political and policy impacts of framing contests. Journal of European Public Policy, 16(1), 81-106.

Borremans, P. (2010). Ready for anything. Communication World, 27(4), 31-33.

Bortree, D. S. (2009). The impact of green initiatives on environmental legitimacy and admiration of the organization. Public Relations Review, 35(2), 133-135. doi:10.1016/j.pubrev.2009.01.002

Bostdorff, D. M. (1992). Idealism held hostage: Jimmy Carter's rhetoric on the crisis in Iran. Communication Studies, 43(1), 14-28.

Botan, C. (1997). Ethics in strategic communication campaigns: The case for a new approach to public relations (Special Issue: Ethics of Business Communication). The Journal of Business Communication, 34(2), 188-203.

Bowen, S. A., \& Zheng, Y. (2015). Auto recall crisis, framing, and ethical response: Toyota's missteps. Public Relations Review, 41 (1), $40-49$. doi:http://dx.doi.org/10.1016/j.pubrev.2014.10.017

Boyd, J. (2000). Actional legitimation: No crisis necessary. Journal of Public Relations Research, 12(4), $341-353$.

Boyd, J., \& Stahey, M. (2008). Communitas/Corporatas tensions in organizational rhetoric: Finding a balance in sports public relations. Journal of Public Relations Research, 20, 251-270. doi:10.1080/10627260801962707

Brecher, M. (1977). Toward a theory of international crisis behavior: A preliminary report. International Studies Quarterly, 39-74.

Breit, E. (2009). On the (Re) construction of corruption in the media: A critical discursive approach. Journal of Business Ethics, 92, 619-635.

Bremser, K., del Mar Alonso-Almeida, M., \& Gohlich, V. (2014). The Relevance of Organizational Characteristics for Crisis Planning. Business and Management Research, 3(4), 26-33. doi:10.5430/bmr.v3n4p26

Brinson, S. L., \& Benoit, W. L. (1996). Dow Corning's image repair strategies in the breast implant crisis. Communication Quarterly, 44(1), 29-41.

Brinson, S. L., \& Benoit, W. L. (1999). The Tarnished Star Restoring Texaco's Damaged Public Image. Management Communication Quarterly, $12(4), 483-510$.

Brønn, P. S., \& Olson, E. L. (1999). Mapping the strategic thinking of public relations managers in a crisis situation: An illustrative example using conjoint analysis. Public Relations Review, 25(3), 351-368.

Brown, E. P., \& Zahrly, J. (1989). Nonmonetary rewards for skilled volunteer labor: A look at crisis intervention volunteers. Nonprofit and Voluntary Sector Quarterly, 18(2), 167-177.

Brown, K. A., Billings, A. C., Mastro, D., \& Brown-Devlin, N. (2015). Changing the Image Repair Equation Impact of Race and Gender on SportRelated Transgressions. Journalism \& Mass Communication Quarterly, 92(2), 487-506. doi:10.1177/1077699015574484

Brown, K. A., \& Ki, E.-J. (2013). Developing a valid and reliable measure of organizational crisis responsibility. Journalism \& Mass Communication Quarterly, 90(2), 363-384. doi:10.1177/1077699013482911

Brown, K. A., \& White, C. L. (2010). Organization-public relationships and crisis response strategies: Impact on attribution of responsibility. Journal of Public Relations Research, 23(1), 75-92.

Brown, N. A., \& Billings, A. C. (2013). Sports fans as crisis communicators on social media websites. Public Relations Review, 39(1), 74-81.

Brown, N. A., Brown, K. A., \& Billings, A. C. (2015). "May No Act of Ours Bring Shame" Fan-Enacted Crisis Communication Surrounding the Penn State Sex Abuse Scandal. Communication \& Sport, 3(3), 288-311. doi:10.1177/2167479513514387

Browning, L. D., \& Shetler, J. C. (1992). Communication in crisis, communication in recovery: a postmodern commentary on the Exxon Valdez disaster. International journal of mass emergencies and disasters, 10(3), 477-498.

Broz, D., Levin, E. C., Mucha, A. P., Pelzel, D., Wong, W., Persky, V. W., \& Hershow, R. C. (2009). Lessons learned from Chicago's emergence response to mass evacuations caused by Hurricane Katrina. American Journal of Public Health, 99(8), 1496-1504. 
Bruce, T., \& Tini, T. (2008). Unique crisis response strategies in sports public relations: Rugby league and the case for diversion. Public Relations Review, 34(2), 108-115.

Brummette, J., \& Sisco, H. F. (2015). Using Twitter as a means of coping with emotions and uncontrollable crises. Public Relations Review, 41(1), 89-96. doi:10.1016/j.pubrev.2014.10.009

Bruns, A., \& Stieglitz, S. (2013). Towards more systematic Twitter analysis: Metrics for tweeting activities. International journal of social research methodology, 16(2), 91-108.

Brynielsson, J., Johansson, F., Jonsson, C., \& Westling, A. (2014). Emotion classification of social media posts for estimating people's reactions to communicated alert messages during crises. Security Informatics, 3(1), 1-11. doi:10.1186/s13388-014-0007-3

Büchel, K. (2013). Do words matter? The impact of communication on the PIIGS'CDS and bond yield spreads during Europe's sovereign debt crisis. European Journal of Political Economy, 32, 412-431. doi:10.1016/j.ejpoleco.2013.08.004

Bundy, J., \& Pfarrer, M. D. (2015). A burden of responsibility: The role of social approval at the onset of a crisis. Academy of Management Review, 40(3), 345-369. doi:http://dx.doi.org/10.5465/amr.2013.0027

Burgess, J., \& Bruns, A. (2013). Cumulative and comparative social media analytics for crisis communication. Selected Papers of Internet Research 14.0.

Burgess, P. G. (1973). Crisis rhetoric: Coercion vs. force. Quarterly Journal of Speech, 59(1), 61-73.

Burnett, J. J. (1998). A strategic approach to managing crises. Public Relations Review, 24(4), 475.

Cahyanto, I., \& Pennington-Gray, L. (2015). Communicating Hurricane Evacuation to Tourists Gender, Past Experience with Hurricanes, and Place of Residence. Journal of Travel Research, 54(3), 329-343. doi:10.1177/0047287513517418

Calloway, L. J., \& Keen, P. G. (1996). Organizing for crisis response. Journal of Information Technology, 11(1), 13-26.

Campbell, E. Q., \& Pettigrew, T. F. (1959). Racial and moral crisis: The role of Little Rock ministers. American Journal of Sociology, 509-516.

Campiranon, K., \& Scott, N. (2014). Critical success factors for crisis recovery management: A case study of Phuket hotels. Journal of Travel \& Tourism Marketing, 31(3), 313-326. doi:10.1080/10548408.2013.877414

Canhoto, A. I., vom Lehn, D., Kerrigan, F., Yalkin, C., Braun, M., \& Steinmetz, N. (2015). Fall and redemption: Monitoring and engaging in social media conversations during a crisis. Cogent Business \& Management, 2(1), 1084978. doi:10.1080/23311975.2015.1084978

Carroll, C. (2009). Defying a reputational crisis--Cadbury's salmonella scare: Why are customers willing to forgive and forget? Corporate reputation review, 12(1), 64-82.

Carroll, J. S., \& Hatakenaka, S. (2001). Driving organizational change in the midst of crisis. Mt. Sloan Management Review(Spring), 70-79.

Castenfors, K., \& Svedin, L. (2001). Crisis communication: learning from the 1998 LPG near miss in Stockholm. Journal of Hazardous Materials, 88(2), 235-254.

Chae, J., Thom, D., Jang, Y., Kim, S., Ertl, T., \& Ebert, D. S. (2014). Public behavior response analysis in disaster events utilizing visual analytics of microblog data. Computers \& Graphics, 38, 51-60. doi:http://dx.doi.org/10.1016/j.cag.2013.10.008

Chang, H. H., Tsai, Y.-C., Wong, K. H., Wang, J. W., \& Cho, F. J. (2015). The effects of response strategies and severity of failure on consumer attribution with regard to negative word-of-mouth. Decision Support Systems, 71, 48-61.

Charlebois, S., Von Massow, M., \& Pinto, W. (2015). Food recalls and risk perception: An exploratory case of the XL Foods and the biggest food recall in Canadian history. Journal of Food Products Marketing, 21(1), 27-43. doi:10.1080/10454446.2013.856055

Chaudhri, V. (2014). Corporate Social Responsibility and the Communication Imperative Perspectives From CSR Managers. International Journal of Business Communication, 1-24. doi:10.1177/2329488414525469

Chen, M. F. (2008). Consumer trust in food safety-a multidisciplinary approach and empirical evidence from Taiwan. Risk Analysis, 28(6), 15531569.

Chen, N. (2009). Institutionalizing public relations: A case study of Chinese government crisis communicationon the 2008 Sichuan earthquake. Public Relations Review, 35, 187-198.

Cheng, S. S. (2013). Crisis communication failure: A case study of typhoon Morakot. Asian Social Science, 9(3), 18. doi:10.5539/ass.v9n3p18

Cheng, Y., Liang, J., \& Leung, L. (2014). Social network service use on mobile devices: An examination of gratifications, civic attitudes and civic engagement in China. new media \& society, 1-21. doi:10.1177/1461444814521362

Cherwitz, R. A. (1980). Masking inconsistency: The Tonkin gulf crisis. Communication Quarterly, 28(2), 27-37.

Cherwitz, R. A., \& Zagacki, K. S. (1986). Consummatory versus justificatory crisis rhetoric. Western Journal of Speech Communication, 50(4), 307324.

Chesler, M., \& Schmuck, R. (1964). Student reactions to the Cuban crisis and public dissent. Public opinion quarterly, 467-482.

Chess, C., Saville, A., Tamuz, M., \& Greenberg, M. (1992). The Organizational Links Between Risk Communication and Risk Management: The Case of Sybron Chemicals Inc. Risk Analysis, 12(3), 431-438.

Chewning, L. V. (2015). Multiple voices and multiple media: Co-constructing BP's crisis response. Public Relations Review, 41(1), 72-79. doi:10.1016/j.pubrev.2014.10.012

Chiciudean, I., \& David, G. (2013). Considerations on using the situational crisis communication theory in the crisis communication planning activities of Romanian Armed Forces Informat. Journal of Defense Resources Management (JoDRM)(01), 159-166.

Cho, S. E., Jung, K., \& Park, H. W. (2013). Social media use during Japan's 2011 earthquake: how Twitter transforms the locus of crisis communication. Media International Australia, 149(1), 28-40.

Cho, S. H., \& Gower, K. K. (2006). Framing effect on the public's response to crisis: Human interest frame and crisis type influencing responsibility and blame. Public Relations Review, 32(4), 420-422.

Choi, J. (2012). A content analysis of BP's press releases dealing with crisis. Public Relations Review, 38, 422-429. doi:http://dx.doi.org/10.1016/j.pubrev.2012.03.003

Choi, J. W., Kim, K. H., Moon, J. M., \& Kim, M. S. (2015). Public health crisis response and establishmentof a crisis communication system in South Korea: lessons learned from the MERS outbreak. Journal of the Korean Medical Association, 58(7), 624-634. doi:http://dx.doi.org/10.5124/jkma.2015.58.7.624

Choi, Y., \& Lin, Y.-H. (2009). Consumer response to crisis: Exploring the concept of involvement in Mattel product recalls. Public Relations Review, 35(1), 18-22.

Diers-Lawson, A. (2017). A state of emergency in crisis communication: An intercultural crisis communication research agenda. Journal of Intercultural Communication Research, 46(1). DOI:10.1080/17475759.2016.1262891. 
Choi, Y., \& Lin, Y.-H. (2009). Consumer responses to Mattel product recalls posted on online bulletin boards: Exploring two types of emotion. Journal of Public Relations Research, 21(2), 198-207.

Choi, Y., \& Lin, Y.-H. (2009). Individual difference in crisis response perception: How do legal experts and lay people perceive apology and compassion responses? Public Relations Review, 35(4), 452-454.

Cicognani, E., \& Zani, B. (2015). Communication of health risks from exposure to depleted uranium (DU) in Italy: a case study. Journal of Risk Research, 18(6), 771-788. doi:10.1080/13669877.2014.913657

Claeys, A., Cauberghe, V. and Vyncke, P. (2010). Restoring reputations in times of crisis: An experimental study of the Situational Crisis Communication Theory and the moderating effects of locus of control. Public Relations Review, 36(3), 256-262. doi:10.1016/j.pubrev.2010.05.004

Claeys, A. S., \& Cauberghe, V. (2014). Keeping control: The importance of nonverbal expressions of power by organizational spokespersons in times of crisis. Journal of Communication, 64(6), 1160-1180. doi:10.1111/jcom.12122

Claeys, A.-S., \& Cauberghe, V. (2014). What makes crisis response strategies work? The impact of crisis involvement and message framing. Journal of Business Research, 67(2), 182-189. doi:http://dx.doi.org/10.1016/j.jbusres.2012.10.005

Claeys, A.-S., \& Cauberghe, V. (2015). The role of a favorable pre-crisis reputation in protecting organizations during crises. Public Relations Review, 41(1), 64-71. doi:10.1016/j.pubrev.2014.10.013

Claeys, A.-S., Cauberghe, V., \& Leysen, J. (2013). Implications of stealing thunder for the impact of expressing emotions in organizational crisis communication. Journal of Applied Communication Research, 41(3), 293-308.

Cmeciu, C., Coman, C., Patrut, M., \& Teodorascu, F. (2015). News Media Framing of Preventable Crisis Clusters. Case Study: Newborn Babies Killed in the Fire at a Romanian Hospital. Transylvanian Review of Administrative Sciences, 11(44), 42-56.

Colapinto, C., \& Benecchi, E. (2014). The presentation of celebrity personas in everyday twittering: managing online reputations throughout a communication crisis. Media, Culture \& Society, 36(2), 219-233. doi:10.1177/0163443714526550

Coleman, A. (2013). Managing a crisis in the era of social communication: how Greater Manchester Police is developing community engagement and communication. Journal of Brand Strategy, 2(2), 128-133.

Comfort, L. K. (2007). Crisis management in hindsight: Cognition, communication, coordination, and control. Public Administration Review, 67(s1), 189-197.

Compton, J., \& Compton, J. L. (2014). College sports, losing seasons, and image repair through open letters to fans. Communication \& Sport, 2(4), 345-362. doi:10.1177/2167479513503542

Conkey, H. (2004). National crisis communication arrangements for agricultural emergencies. Australian Journal of Emergency Management, The, 19(3), 43.

Conway, T., Ward, M., Lewis, G., \& Bernhardt, A. (2007). Internet crisis potential: The importance of a strategic approach to marketing communications. Journal of Marketing Communication, 13(3), 213-228. doi:10.1080/13527260601086462

Cooley, S., \& Jones, A. (2013). A forgotten tweet: Somalia and social media. Ecquid Novi: African Journalism Studies, 34(1), 68-82.

Coombs, T., \& Holladay, S. (2015). CSR as crisis risk: expanding how we conceptualize the relationship. Corporate Communications: An International Journal, 20(2), 144-162. doi:http://dx.doi.org/10.1108/CCIJ-10-2013-0078

Coombs, T. W., Frandsen, F., Holladay, S. J., \& Johansen, W. (2010). Why a concern for apologia and crisis communication? Corporate Communications: An International Journal, 15(4), 337-349.

Coombs, T. W., \& Holladay, S. J. (2006). Unpacking the halo effect: reputation and crisis management. Journal of Communication Management, $10(2), 123-137$.

Coombs, T. W., \& Holladay, S. J. (2014). How publics react to crisis communication efforts: Comparing crisis response reactions across subarenas. Journal of Communication Management, 18(1), 40-57.

Coombs, W. T. (1995). Choosing the right words the development of guidelines for the selection of the "appropriate" crisis-response strategies. Management Communication Quarterly, 8(4), 447-476.

Coombs, W. T. (1998). An analytic framework for crisis situations: Better responses from a better understanding of the situation. Journal of Public Relations Research, 10(3), 177-191.

Coombs, W. T. (1999). Information and compassion in crisis responses: A test of their effects. Journal of Public Relations Research, 11(2), 125142.

Coombs, W. T. (2000). Designing post-crisis messages: Lessons for crisis response strategies. Review of Business, 21(3/4), 37-41.

Coombs, W. T. (2004). Impact of past crises on current crisis communication: Insights from Situational Crisis Communication Theory. The Journal of Business Communication, 41(3), 265-290.

Coombs, W. T. (2004). West Pharmaceutical's explosion: Structuring crisis discourse knowledge. Public Relations Review, 30(4), 467-473.

Coombs, W. T. (2006). The protective powers of crisis response strategies: Managing reputational assets during a crisis. Journal of Promotion Management, 12(3/4), 241-260. doi:10.1300/J057v12n03•13

Coombs, W. T. (2007). Attribution theory as a guide for post-crisis communication research. Public Relations Review, 33(2), 135-139.

Coombs, W. T. (2007). Protecting organization reputation during a crisis: The development and application of situational crisis communication theory. Corporate reputation review, 10(3), 163-176.

Coombs, W. T. (2014). State of Crisis Communication: Evidence and the Bleeding Edge. Research Journal of the Institute for Public Relations, $1(1), 1-12$.

Coombs, W. T. (2014). The value of communication during a crisis: Insights from strategic communication research. Business Horizons, 58(2), 141-148. doi:http://dx.doi.org/10.1016/j.bushor.2014.10.003

Coombs, W. T. (2015). The value of communication during a crisis: Insights from strategic communication research. Business Horizons, 58(2), 141-148. doi:http://dx.doi.org/10.1016/j.bushor.2014.10.003

Coombs, W. T., \& Holladay, S. (2007). The negative communication dynamic: Exploring the impact of stakeholder affect on behavioral intentions. Journal of Communication Management, 11(4), 300-312.

Coombs, W. T., \& Holladay, S. (2012). The paracrisis: The challenges created by publicly managing crisis prevention. Public Relations Review, 38, 408-415. doi:http://dx.doi.org/10.1016/j.pubrev.2012.04.004 
Coombs, W. T., \& Holladay, S. J. (1996). Communication and attributions in a crisis: An experimental study in crisis communication. Journal of Public Relations Research, 8(4), 279-295.

Coombs, W. T., \& Holladay, S. J. (2001). An extended examination of the crisis situations: A fusion of the relational managment and symbolic approaches. Journal of Public Relations Research, 13(4), 321-340.

Coombs, W. T., \& Holladay, S. J. (2002). Helping crisis managers protect their reputational assets: Initial tests of the Situational Crisis Communication Theory. Management Communication Quarterly, 16(2), 165-186.

Coombs, W. T., \& Holladay, S. J. (2009). Further explorations of post-crisis communication: Effects of media and response strategies on perceptions and intentions. Public Relations Review, 35(1), 1-6. doi:10.1016/j.pubrev.2008.09.011

Coombs, W. T., \& Holladay, S. J. (2015). Public relations'"relationship identity" in research: Enlightenment or illusion. Public Relations Review, 41(5), 689-695. doi:http://dx.doi.org/10.1016/j.pubrev.2013.12.008

Coombs, W. T., \& Schmidt, L. (2000). An empirical analysis of image restoration: Texaco's racism crisis. Journal of Public Relations Research, 12(2), 163-178.

Coppetti, C., Wentzel, D., Tomczak, T., \& Henkel, S. (2009). Improving incongruent sponsorships through articulation of the sponsorship and audience participation. Journal of Marketing Communication, 15(1), 17-34.

Cortiñas-Rovira, S., Pont-Sorribes, C., \& Alonso-Marcos, F. (2015). Simulating and Dissimulating News: Spanish Media Coverage of the Swine Flu Virus. Journal of Contingencies and Crisis Management, 23(3), 159-168. doi:10.1111/1468-5973.12063

Covello, V. T., Peters, R. G., Wojtecki, J. G., \& Hyde, R. C. (2001). Risk communication, the West Nile virus epidemic, and bioterrorism: responding to the commnication challenges posed by the intentional or unintentional release of a pathogen in an urban setting. Journal of Urban Health, 78(2), 382-391.

Cowen, A. P., \& Cowen, S. S. (2010). Rediscovering communities: Lessons from the Hurricane Katrina crisis. Journal of Management Inquiry, 19(117), 117-125. doi:10.1177/1056492609351089

Danowski, J. A., \& Edison-Swift, P. (1985). Crisis effects on intraorganizational computer-based communication. Communication Research, 12(2), 251-270.

Dardis, F., \& Haigh, M. M. (2009). Prescribing versus describing: Testing image restoration strategies in a crisis situation. Corporate Communications: An International Journal, 14(1), 101-118.

Davison, W. P. (1959). On the effects of communication. Public opinion quarterly, 23(3), 343-360.

Dawar, N., \& Lei, J. (2009). Brand crises: The roles of brand familiarity and crisis relevance in determining the impact on brand evaluations. Journal of Business Research, 62, 509-516. doi:10.1016/j.jbusres.2008.02.001

de Brooks, K. P., \& Waymer, D. (2009). Public relations and strategic issues management challenges in Venezuela: A discourse analysis of Crystallex International Corporation in Las Cristinas. Public Relations Review, 35, 31-39.

De Bruycker, I., \& Walgrave, S. (2014). How a new issue becomes an owned issue. Media coverage and the financial crisis in Belgium (20082009). International Journal of Public Opinion Research, 26(1), 86-97.

de Fatima Oliveira, M. (2013). Multicultural environments and their challenges to crisis communication. Journal of Business Communication, 0021943613487070. doi:10.1177/0021943613487070

De Wolf, D., \& Mejri, M. (2013). Crisis Communication failures: The BP case study. International Journal of Advances in Management and Economics, 2(2), 48-56.

Dean, D. H. (2004). Consumer reaction to negative publicity effects of corporate reputation, response, and responsibility for a crisis event. Journal of Business Communication, 41(2), 192-211.

Deverell, E., Olsson, E. K., Wagnsson, C., Hellman, M., \& Johnsson, M. (2015). Understanding public agency communication: the case of the Swedish armed forces. Journal of Public Affairs, 15(4), 387-396. doi:10.1002/pa.1552

Dickmann, P., Biedenkopf, N., Keeping, S., Eickmann, M., \& Becker, S. (2014). Risk communication and crisis communication infectious disease outbreaks in Germany: what is being done, and what needs to be done. Disaster Med Public Health Prep, 8, 206-211. doi:10.1017/dmp.2014.36

Dickmann, P., McClelland, A., Gamhewage, G. M., de Souza, P. P., \& Apfel, F. (2015). Making sense of communication interventions in public health emergencies-an evaluation framework for risk communication. Journal of Communication in Healthcare, 233-240. doi:10.1080/17538068.2015.1101962

Diers, A. R., \& Donohue, J. (2013). Synchronizing crisis responses after a transgression: An analysis of BP's enacted crisis response to the Deepwater Horizon crisis in 2010. Journal of Communication Management, 17(3), 252-269.

Diers, A. R., \& Tomaino, K. (2010). Comparing strawberries and quandongs: A cross-national analysis of crisis response strategies. Observatorio, $4(2), 21=57$.

Difonzo, N., Bordia, P., \& Rosnow, R. L. (1994). Reining in rumors. Organizational Dynamics, 23(1), 47-62.

Dilenschneider, R. L., \& Hyde, R. C. (1985). Crisis communications: Planning for the unplanned. Business Horizons, 35-38.

DiStaso, M. W. (2010). Industry in crisis: The communication challenge in the banking industry. Public Relations Journal, 4(1), 1-17.

DiStaso, M. W., Vafeiadis, M., \& Amaral, C. (2015). Managing a health crisis on Facebook: How the response strategies of apology, sympathy, and information influence public relations. Public Relations Review, 41(2), 222-231. doi:10.1016/j.pubrev.2014.11.014

Doepel, D. G. (1991). Crisis management: the psychological dimension. Organization \& Environment, 5(3), 177-188.

Downing, J. R. (2004). American Airlines' use of mediated employee channels after the 9/11 attacks. Public Relations Review, 30(1), 37-48.

Dufty, N. (2015). The use of social media in countrywide disaster risk reduction public awareness strategies. Australian Journal of Emergency Management, The, 30(1), 12.

Duhamel, C. (2013). Using lessons from SARS in tackling swine flu: Looking inward to develop a crisis communication model. Journal of Communication in Healthcare, 395-410. doi:10.1179/cih.2009.2.4.395

Duhe, S., \& Zoch, L. (1994). Framing the Media's Agenda During a Crisis. Public Relations Quarterly, 39(4), $42-45$.

Duke, S., \& Masland, L. (2002). Crisis communication by the book. Public Relations Quarterly, 47(3), 30.

Dutta-Bergman, M. J. (2006). Community participation and Internet use after September 11: Complementarity in channel consumption. Journal of Computer-Mediated Communication, 11(2), 469-484.

Dutton, J. E. (1986). The processing of crisis and non-crisis strategic issues. Journal of management studies, 23(5), 501-517. 
Einwiller, S. A., Carroll, C. E., \& Korn, K. (2010). Under what conditions do the news influence corporate reputation? The roles of media dependency and need for orientation. Corporate reputation review, 12(4), 299-315.

Einwiller, S. A., \& Steilen, S. (2015). Handling complaints on social network sites-An analysis of complaints and complaint responses on Facebook and Twitter pages of large US companies. Public Relations Review, 41(2), 195-204. doi:10.1016/j.pubrev.2014.11.012

Elsbach, K. D. (1994). Managing organizational legitimacy in the California cattle industry: The constuction and effectiveness of verbal accounts. Administrative science quarterly, 39, 57-88.

Elsbach, K. D., \& Elofson, G. (2000). How the packaging of decision explanations affects perceptions of trustworthiness. Academy of Management Journal, 43(1), 80-89.

Elsbach, K. D., \& Sutton, R. I. (1992). Acquiring organizational legitimacy through illegitimate actions: A marriage of institutional and impression management theories. Academy of Management Journal, 33(4), 699-738.

Elsbach, K. D., Sutton, R. I., \& Principe, K. E. (1998). Averting expected challenges through anticipatory impression management: A study of hospital billing. Organization Science, 9(1), 68-86.

Erickson, B. H., Nosanchuk, T., Mostacci, L., \& Dalrymple, C. F. (1978). The flow of crisis information as a probe of work relations. Canadian Journal of Sociology/Cahiers canadiens de sociologie, 71-87.

Etter, M. A., \& Vestergaard, A. (2015). Facebook and the public framing of a corporate crisis. Corporate Communications: An International Journal, 20(2), 163-177. doi:http://dx.doi.org/10.1108/CCIJ-10-2013-0082

Falkheimer, J. (2014). Crisis communication and terrorism: the Norway attacks on 22 July 2011. Corporate Communications: An International Journal, 19(1), 52-63. doi:http://dx.doi.org/10.1108/CCIJ-08-2012-0053

Falkheimer, J., \& Heide, M. (2006). Multicultural crisis communication: Toward a social constructionist perspective. Journal of Contingencies \& Crisis Management, 14(4), 180-189.

Falkheimer, J., \& Heide, M. (2015). Trust and Brand Recovery Campaigns in Crisis: Findus Nordic and the Horsemeat Scandal. International Journal of Strategic Communication, 9(2), 134-147. doi:10.1080/1553118X.2015.1008636

Falkheimer, J., \& Olsson, E.-K. (2015). Depoliticizing terror: The news framing of the terrorist attacks in Norway, 22 July 2011. Media, War \& Conflict, 8(1), 70-85. doi:10.1177/1750635214531109

Farmer, B., \& Tyedt, L. (2005). Top management communication during crises: guidelines and a 'perfect example' of a crisis leader. Public Relations Quarterly, 50(2), 27-31. doi:898489731

Figueroa, P. M. (2013). Risk communication surrounding the Fukushima nuclear disaster: an anthropological approach. Asia Europe Journal, 11(1), 53-64.

Fink, S. L., Beak, J., \& Taddeo, K. (1971). Organizational crisis and change. The Journal of applied behavioral science, 7(1), 15-37.

Fischbacher-Smith, D. (2014). Organisational ineffectiveness: Environmental shifts and the transition to crisis. Journal of Organizational Effectiveness: People and Performance, 1(4), 423-446. doi:http://dx.doi.org/10.1108/JOEPP-09-2014-0061

Fishman, D. A. (1999). ValuJet Flight 592: Crisis communication theory blended and extended. Communication Quarterly, 47(4), 345-365.

Folkes, V. S., \& Karmins, M. A. (1999). Effects of information about firms' ethical and unethical actions on consumers' attitudes. Journal of Consumer Psychology, 8(3), 243-259.

Fortunato, J. A. (2008). Restoring a reputation: The Duke University lacrosse scandal. Public Relations Review, 34(2), 116-123.

Frandsen, F., \& Johansen, W. (2007). The apology of a sports icon: Crisis communication and apologetic ethics. Hermes, Journal of Linguistics, 38, 85-104.

Frandsen, F., \& Johansen, W. (2009). Institutionalizing crisis communication in the public sector: An explorative study in Danish municipalities. International Journal of Strategic Communication, 3(2), 102-115.

Frandsen, F., \& Johansen, W. (2010). Apologizing in a globalizing world: crisis communication and apologetic ethics. Corporate Communications: An International Journal, 15(4), 350-364. doi:2241134471

Fraustino, J. D., \& Ma, L. (2015). CDC's Use of Social Media and Humor in a Risk Campaign - “Preparedness 101: Zombie Apocalypse”. Journal of Applied Communication Research, 43(2), 222-241. doi:10.1080/00909882.2015.1019544

Freberg, K. (2012). Intention to comply with crisis messages communicated via social media. Public Relations Review, 38, 416-421. doi:doi:10.1016/j.pubrev.2012.01.008

Freberg, K. (2013). Using the theory of planned behavior to predict intention to comply with a food recall message. Health communication, 28(4), 359-365. doi:10.1080/10410236.2012.688657

Freberg, K., Palenchar, M. J., \& Veil, S. R. (2013). Managing and sharing H1N1 crisis information using social media bookmarking services. Public Relations Review, 39(3), 178-184. Retrieved from http://dx.doi.org/10.1016/j.pubrev.2013.02.007

Freberg, K., Saling, K., Vidoloff, K. G., \& Eosco, G. (2013). Using value modeling to evaluate social media messages: The case of Hurricane Irene. Public Relations Review, 39(3), 185-192. doi:http://dx.doi.org/10.1016/j.pubrev.2013.02.010

Freberg, K. J., Saling, K., \& Freberg, L. (2013). Using a Situational Q-Sort to Assess Perceptions of a Food Recall Message as a Function of Delivery via Social, Organizational or Traditional Media. Journal of Contingencies and Crisis Management, 21(4), 225-230. doi:10.1111/14685973.12026

Fredriksson, M. (2014). Crisis communication as institutional maintenance. Public Relations Inquiry, 3(3), 319-340. doi:10.1177/2046147X14536724

Frewer, L., Fischer, A., Brennan, M., Bánáti, D., Lion, R., Meertens, R., .. Vereijken, C. (2014). Risk/benefit communication about food-a systematic review of the literature. Critical reviews in food science and nutrition, 56(10), 1728-1745. doi:10.1080/10408398.2013.801337

Frisby, B. N., Sellnow, D. D., Lane, D. R., Veil, S. R., \& Sellnow, T. L. (2013). Instruction in crisis situations: Targeting learning preferences and selfefficacy. Risk Management, 15(4), 250-271. doi:10.1057/rm.2013.7

Frisby, B. N., Veil, S. R., \& Sellnow, T. L. (2014). Instructional messages during health-related crises: essential content for self-protection. Health communication, 29(4), 347-354. doi:10.1080/10410236.2012.755604

Frynas, J. (2005). The false developmental promise of corporate social responsibility: Evidence from multinational oil companies. International Affairs, 81(3), 581-598. doi:10.1111/j.1468-2346.2005.00470.x

Gainey, B. S. (2009). Crisis management's new role in educational settings. The Clearing House, 82(6), 267-274.

Diers-Lawson, A. (2017). A state of emergency in crisis communication: An intercultural crisis communication research agenda. Journal of Intercultural Communication Research, 46(1). DOI:10.1080/17475759.2016.1262891. 
Garnett, J., \& Kouzmin, A. (2009). Crisis communication post Katrina: what are we learning? Public Organization Review, 9(4), 385-398. Gesser-Edelsburg, A., Shir-Raz, Y., Hayek, S., \& Lev, O. S.-B. (2015). What does the public know about Ebola? The public's risk perceptions regarding the current Ebola outbreak in an as-yet unaffected country. American journal of infection control, 43(7), 669-675. doi:http://dx.doi.org/10.1016/j.ajic.2015.03.005

Gilbert, A. N., \& Lauren, P. G. (1980). Crisis Management An Assessment and Critique. Journal of Conflict Resolution, 24(4), 641-664.

Ginzel, L. E., Kramer, R. M., \& Sutton, R. I. (1993). Organizational impression management as a reciprocal influence process: The neglected role of the organizational audience. Research in Organizational Behavior, 15, 227-266.

Gittell, J. H., Cameron, K., Lim, S., \& Rivas, V. (2006). Relationships, layoffs, and organizational resilience: Airline industry responses to September 11. The Journal of applied behavioral science, 42(3), 300-329. doi:10.1177/0021886306286466

Glendon, A., McDonald, L., \& Sparks, B. (2010). Stakeholder reactions to company crisis communication and causes. Public Relations Review, 36, 263-271. doi:10.1016/j.pubrev.2010.04.004

Goby, V. P., \& Nickerson, C. (2015). The impact of culture on the construal of organizational crisis: perceptions of crisis in Dubai. Corporate Communications: An International Journal, 20(3), 310-325.

Goh, O. S., Fung, C. C., \& Lee, M. P. (2005). Intelligent agents for an Internet-based global crisis communication system. Journal of Technology Management and Entrepreneurship, 2(1), 65-78.

Gonzales-Herrero, A., \& Pratt, C. B. (1996). An integrated symmetrical model for crisis-communications management. Journal of Public Relations Research, 8(2), 79-105.

Gonzales-Herrero, A., \& Pratt, C. B. (1998). Marketing crises in tourism: Communication strategies in the United States and Spain. Public Relations Review, 24(1), 83-97.

Göritz, A., Schultz, F., \& Utz, S. (2011). Is the Medium the Message? Perceptions of an reactions to crisis communication via twitter, blogs and traditional media. Public Relations Review, 37(1), 20-27. doi:10.1016/j.pubrev.2010.12.001

Goyal, R., \& Negi, D. (2014). Impact of global economic crisis on airline industry. International Journal of Commerce, Business and Management, 3(2), 297-301.

Graham, M. W., Avery, E. J., \& Park, S. (2015). The role of social media in local government crisis communications. Public Relations Review, 41(3), 386-394. doi:http://dx.doi.org/10.1016/j.pubrev.2015.02.001

Grappi, S., \& Romani, S. (2015). Company post-crisis communication strategies and the psychological mechanism underlying consumer reactions. Journal of Public Relations Research, 27(1), 22-45. doi:10.1080/1062726X.2014.924839

Grebe, S. K. (2013). Re-Building a Damaged Corporate Reputation: How the Australian Wheat Board (AWB) Overcame the Damage of the UN 'Oil For Food'Scandal to Successfully Reintegrate into the Australian Wheat Marketing Regulatory Regime. Corporate reputation review, 16(2), 118-130. doi:10.1057/crr.2013.5

Grebe, S. K. (2013). Things can get worse: How mismanagement of a crisis response strategy can cause a secondary or double crisis: the example of the AWB corporate scandal. Corporate Communications: An International Journal, 18(1), 70-86. doi:http://dx.doi.org/10.1108/13563281311294137

Greenberg, B. S. (1964). Person-to-person communication in the diffusion of news events. Journalism and Mass Communication Quarterly, 41(4), 489.

Greer, C. F., \& Moreland, K. D. (2003). United Airlines' and American Airlines' online crisis communication following the September 11 terrorist attacks. Public Relations Review, 29, 427-441.

Gregoire, Y., \& Fisher, R. J. (2008). Customer betrayal and retaliation: when your best customers become your worst enemies. Journal of the Academy of Marketing Science, 36(2), 247-261. doi:10.1007/s11747-007-0054-0

Greyser, S. A. (1999). Advancing and enhancing corporate reputation. Corporate Communications: An International Journal, 4(4), $177-181$.

Griffin-Padgett, D., \& Allison, D. (2010). Making a case for restorative rhetoric: Mayor Rudolph Giuliani and Mayor Ray Nagin's response to disaster. Communication Monographs, 77(3), 376-392. doi:10.1080/03637751.2010.502536

Grossberg, L. (1979). Interpreting the "crisis" of culture in communication theory. Journal of Communication, 29(1), 56-68.

Gruber, D. A., Smerek, R. E., Thomas-Hunt, M. C., \& James, E. H. (2015). The real-time power of Twitter: Crisis management and leadership in an age of social media. Business Horizons, 58(2), 163-172. doi:10.1016/j.bushor.2014.10.006

Grundy, M., \& Moxon, R. (2013). The effectiveness of airline crisis management on brand protection: A case study of British Airways. Journal of Air Transport Management, 28, 55-61. doi:http://dx.doi.org/10.1016/j.jairtraman.2012.12.011

Gu, Q. (2014). Sina Weibo: A mutual communication apparatus between the Chinese government and Chinese citizens. China Media Research, $10(2), 72-86$

Gurman, T. A., \& Ellenberger, N. (2015). Reaching the global community during disasters: findings from a content analysis of the organizational use of Twitter after the 2010 Haiti earthquake. Journal of Health Communication, 20(6), 687-696. doi:10.1080/10810730.2015.1018566

Ha, J. H., \& Boynton, L. (2014). Has crisis communication been studied using an interdisciplinary approach? A 20-year content analysis of communication journals. International Journal of Strategic Communication, 8(1), 29-44. doi:10.1080/1553118X.2013.850694

Haddon, A., Loughlin, C., \& McNally, C. (2015). Leadership in a time of financial crisis: what do we want from our leaders? Leadership \& Organization Development Journal, 36(5), 612-627. doi:http://dx.doi.org/10.1108/LODJ-12-2013-0166

Hafez, K. (1996). The Algerian crisis as portrayed in the German press: Media coverage of political Islam. Communications, 21(2), 155-182.

Haigh, M. M., \& Brubaker, P. (2010). Examining how image restoration strategy impacts perceptions of corporate social responsibility, organization public relationships, and source credibility. Corporate Communications: An International Journal, 15(4), 453-468. doi:10.1108/13563281011085538

Hajibaba, H., Gretzel, U., Leisch, F., \& Dolnicar, S. (2015). Crisis-resistant tourists. Annals of Tourism Research, 53, 46-60. doi:10.1016/j.annals.2015.04.001

Hale, J. E., Dulek, R., \& Hale, D. (2005). Crisis response communication challenges building theory from qualitative data. Journal of Business Communication, 42(2), 112-134.

Hargis, M., \& Watt, J. D. (2010). Organizational perception management: A framework to overcome crisis events. Organizational Development Journal, 28(1), 73-87.

Diers-Lawson, A. (2017). A state of emergency in crisis communication: An intercultural crisis communication research agenda. Journal of Intercultural Communication Research, 46(1). DOI:10.1080/17475759.2016.1262891. 
Harmon, S. J. (1971). Crisis: Group Response to Emergency. Journal of Communication, 21(3), $266-272$.

Haruta, A., \& Hallahan, K. (2003). Cultural issues in airline crisis communications: A Japan-US comparative study. Asia Journal of Communication, 13(2), 122-150.

Hass, J. W., Bagley, G. S., \& Rogers, R. W. (1975). Coping with the energy crisis: Effects of fear appeals upon attitudes toward energy consumption. Journal of Applied Psychology, 60(6), 754.

Hätty, H., \& Hollmeier, S. (2003). Airline strategy in the 2001/2002 crisis-the Lufthansa example. Journal of Air Transport Management, 9(1), 51-55.

Haworth, B., \& Bruce, E. (2015). A review of volunteered geographic information for disaster management. Geography Compass, 9(5), 237-250. doi:10.1111/gec3.12213

Hayes, D., \& Patton, M. (2001). Proactive crisis-management strategies and the archaeological heritage. International Journal of Heritage Studies, 7(1), 37-58.

Hazleton, V., \& Kennan, W. (2000). Social capital: reconceptualizing the bottom line. Corporate Communications: An International Journal, 5(2), 81-87.

Hearit, K. M. (1994). Apologies and public relations crises at Chrysler, Toshiba, and Volvo. Public Relations Review, 20(2), $113-125$.

Hearit, K. M. (1995). “Mistakes were made”: Organizations, apologia, and crises of social legitimacy. Communication Studies, $46(1-2), 1-17$.

Hearit, K. M. (1999). Newsgroups, activist publics, and corporate apologia: The case of Intel and its Pentium chip. Public Relations Review, 25(3), 291-308.

Hearit, K. M., \& Courthright, J. L. (2003). A social constructionist approach to crisis managment: Allegations of sudden acceleration in the Audi 5000. Communication Studies, 54(1), 79-96.

Heath, R. (1998). Dealing with the complete crisis-the crisis management shell structure. Safety Science, 30(1), 139-150.

Heath, R. (1998). Looking for answers: suggestions for improving how we evaluate crisis management. Safety Science, 30(1), $151-163$.

Heath, R. (1998). Working under pressure: crisis management, pressure groups and the media. Safety Science, 30(1), 209-221.

Heath, R., Lee, J., \& Ni, L. (2009). Crisis and risk approaches to emergency management planning and communication: The role of similarity and sensitivity. Journal of Public Relations Research, 21(2), 123-141. doi:10.1080/10627260802557415

Heath, R. L. (1998). Dealing with the complete crisis--the crisis management shell structure. Safety Science, 30, $139-150$.

Heath, R. L. (1998). Working under pressure: Crisis management, pressure groups and the media. Safety Science, $209-221$.

Heath, R. L., Lee, J., \& Ni, L. (2009). Crisis and risk approaches to emergency management planning and communication: The role of similarity and sensitivity. Journal of Public Relations Research, 21(2), 123-141.

Heide, M., \& Simonsson, C. (2014). Developing internal crisis communication: New roles and practices of communication professionals. Corporate Communications: An International Journal, 19(2), 128-146.

Heide, M., \& Simonsson, C. (2015). Struggling with internal crisis communication: A balancing act between paradoxical tensions. Public Relations Inquiry, 4(2), 223-255. doi:10.1177/2046147X15570108

Heinze, J., Uhlmann, E. L., \& Diermeier, D. (2014). Unlikely allies: credibility transfer during a corporate crisis. Journal of Applied Social Psychology, 44(5), 392-397. doi:10.1111/jasp.12227

Helm, S., \& Tolsdorf, J. (2013). How does corporate reputation affect customer loyalty in a corporate crisis? Journal of Contingencies and Crisis Management, 21(3), 144-152. doi:10.1111/1468-5973.12020

Helsloot, I. (2005). Bordering on reality: Findings on the bonfire crisis management simulation. Journal of Contingencies and Crisis Management, 13(4), 159-169.

Helsloot, I., \& Groenendaal, J. (2013). Twitter: An Underutilized Potential during Sudden Crises? Journal of Contingencies and Crisis Management, 21(3), 178-183. doi:10.1111/1468-5973.12023

Henderson, J. C. (1999). Tourism management and the Southeast Asian economic and environmental crisis: a Singapore perspective. Managing Leisure, 4(2), 107-120.

Henderson, J. C. (2003). Communicating in a crisis: Flight SQ 006. Tourism management, 24, $279-287$.

Hermann, C. F. (1963). Some consequences of crisis which limit the viability of organizations. Administrative science quarterly, $61-82$.

Hobbins, J., \& Enander, A. (2015). Citizens and Contingencies--Swedish Crisis Managers' Views of The Public. International Journal of Mass Emergencies \& Disasters, 33(3).

Hobbs, J. D. (1995). Treachery by any Other Name A Case Study of the Toshiba Public Relations Crisis. Management Communication Quarterly, $8(3), 323-346$.

Holladay, S. J. (2009). Crisis communication strategies in the media coverage of chemical accidents. Journal of Public Relations Research, 21(2), 208-217.

Holtzhausen, D. R., \& Roberts, G. F. (2009). An Investigation into the Role of Image Repair Theory in Strategic Conflict Management. Journal of Public Relations Research, 21(2), 165-186. doi:10.1080/10627260802557431

Horton, T. R. (1988). Crisis management. Management Review, 77(9), 5-8.

Hossain, L., Murshed, S. T., \& Uddin, S. (2013). Communication network dynamics during organizational crisis. Journal of Informetrics, 7(1), 1635. doi:http://dx.doi.org/10.1016/j.joi.2012.07.006

Hosseinali Mirza, V., de Marcellis-Warin, N., \& Warin, T. (2015). Crisis Communication Strategies and Reputation Risk in the Online Social Media Environment. International Journal of Business and Social Science, 6(5).

Houston, J. B., Hawthorne, J., Perreault, M. F., Park, E. H., Goldstein Hode, M., Halliwell, M. R., . . McElderry, J. A. (2015). Social media and disasters: a functional framework for social media use in disaster planning, response, and research. Disasters, 39(1), 1-22. doi:10.1111/disa.12092

Howell, G., \& Miller, R. (2006). How the relationship between the crisis life cycle and mass media content can better inform crisis communication. PRism, 4(1), 1-14.

Huang, Y. (2008). Trust and relational commitment in corporate crises: The effects of crisis communicative strategy and form of crisis response. Journal of Public Relations Research, 20(297-327).

Huang, Y.-H., Lin, Y.-H., \& Su, S.-H. (2005). Crisis communicative strategies in Taiwan: Category, continuum, and cultural implication. Public Relations Review, 31(2), 229-238.

Diers-Lawson, A. (2017). A state of emergency in crisis communication: An intercultural crisis communication research agenda. Journal of Intercultural Communication Research, 46(1). DOI:10.1080/17475759.2016.1262891. 
Huang, Y.-H., \& Su, S.-H. (2009). Determinants of consistent, timely, and active responses in corporate crises. Public Relations Review, 35(1), 717.

Huber, F., Vollhardt, K., Matthes, I., \& Vogel, J. (2010). Brand misconduct: Consequences on consumer-brand relationships. Journal of Business Research, 63, 1113-1120. doi:10.1016/j.jbusres.2009.10.006

Husain, K., Abdullah, A. N., Ishak, M., Kamarudin, M. F., Robani, A., Mohin, M., \& Hassan, S. N. S. (2014). A preliminary study on effects of social media in crisis communication from public relations practitioners' views. Procedia-Social and Behavioral Sciences, $155,223-227$. doi:10.1016/j.sbspro.2014.10.283

Hutchison, E. (2010). Trauma and the politics of emotions: Constituting identity, security, and community after the Bali bombing. International Relations, 24(1), 65-86.

Huzey, D., Betts, S. C., \& Vicari, V. (2014). Learning the hard way vs. vicarious learning: Post crisis learning for small business. Journal of management and marketing research, 15, 1.

Hwang, S., \& Cameron, G. T. (2008). Public's expectation about an organization's stance in crisis communication based on perceived leadership and perceived severity of threats. Public Relations Review, 34(1), 70-73.

Hwang, S., \& Cameron, G. T. (2009). The estimation of a corporate crisis communication. Public Relations Review, 35(2), $136-138$.

Hyvärinen, J., \& Vos, M. (2015). Developing a conceptual framework for investigating communication supporting community resilience. Societies, 5(3), 583-597. doi:10.3390/soc5030583

Iannarino, N. T., Veil, S. R., \& Cotton, A. J. (2015). Bringing home the crisis: How US evening news framed the 2011 Japan nuclear crisis. Journal of Contingencies and Crisis Management, 23(3), 169-181. doi:10.1111/1468-5973.12068

Ice, R. (1991). Corporate Publics and Rhetorical Strategies The Case of Union Carbide's Bhopal Crisis. Management Communication Quarterly, $4(3), 341-362$.

Ihlen, $\varnothing$. (2002). Defending the Mercedes A-Class: Combining and Changing Crisis-Response Strategies. Journal of Public Relations Research, 14(3), 185-206. doi:10.1207/S1532754XJPRR1403_2

Iyengar, S., Curran, J., Lund, A., Salovaara-Moring, I., Hahh, K., \& Coen, S. (2010). Cross-national versus individual-level differences in political information: A media systems perspective. Journal of Elections, Public Opinion, and Parties, 20(3), 291-309.

lyengar, S., \& Simon, A. (1993). News coverage of the Gulf crisis and public opinion a study of agenda-setting, priming, and framing. Communication Research, 20(3), 365-383.

Jamal, J., \& Bakar, H. A. (2015). The Mediating Role of Charismatic Leadership Communication in a Crisis A Malaysian Example. International Journal of Business Communication, 1-25. doi:10.1177/2329488415572782

Jameson, D. A. (2009). Economic crises and financial disasters: The role of business communication. Journal of Business Communication, 46(4), 499-509.

Jaques, T. (2009). Issue and crisis management: Quicksand in the definitional landscape. Public Relations Review, 35(3), $280-286$.

Jaques, T. (2009). Issue management as a post-crisis discipline: Identifying and responding to issue impacts beyond the crisis. Journal of Public Affairs, 9(1), 35-44.

Jerome, A. M. (2008). Toward prescription: Testing the rhetoric of atonement's applicability in the athletic arena. Public Relations Review, 34(2), 124-134. doi:10.1016/j.pubrev.2008.03.007

Jin, Y. (2009). The effects of public's cognitive appraisal of emotions in crises on crisis coping and strategy assessment. Public Relations Review, 35(3), 310-313.

Jin, Y. (2010). Making sense sensibly in crisis communication: How publics' crisis appraisals influence their negative emotions, coping strategy preferences, and crisis response acceptance. Communication Research, 37(4), 522-552. doi:10.1177/0093650210368256

Jin, Y. (2014). Examining publics' crisis responses according to different shades of anger and sympathy. Journal of Public Relations Research, 26(1), 79-101. doi:10.1080/1062726X.2013.848143

Jin, Y., \& Cameron, G. T. (2007). The effects of threat type and duration on public relations practitioner's cognitive, affective, and conative responses in crisis situations. Journal of Public Relations Research, 19(3), 255-281.

Jin, Y., Liu, B. F., Anagondahalli, D., \& Austin, L. (2014). Scale development for measuring publics' emotions in organizational crises. Public Relations Review, 40(3), 509-518. doi:http://dx.doi.org/10.1016/j.pubrev.2014.04.007

Jin, Y., Pang, A., \& Cameron, G. T. (2007). Integrated crisis mapping: Towards a publics-based, emotion-driven conceptualization in crisis communication. Sphera Publica, 7(1), 81-96.

Jin, Y., Park, S.-A., \& Len-Ríos, M. E. (2010). Strategic communication of hope and anger: A case of Duke University's conflict management with multiple publics. Public Relations Review, 36(1), 63-65.

Jindal, S., Laveena, L., \& Aggarwal, A. (2015). A Comparitive Study Of Crisis Management-Toyota V/S General Motors. Scholedge International Journal of Management \& Development, 2(6), 1-12.

Johansson, A., \& Härenstam, M. (2013). Knowledge communication: a key to successful crisis management. Biosecurity and bioterrorism: biodefense strategy, practice, and science, 11(S1), S260-S263. doi:10.1089/bsp.2013.0052

Johnson, D., \& Sellnow, T. L. (1995). Deliberative rhetoric as a step in organizational crisis management: Exxon as a case study. Communication Reports, 8(1), 54-60.

Jones Jr, J. V. (1983). Crisis management and media relations. NASPA Journal, 21(2), 36-40.

Joris, W., d'Haenens, L., \& Van Gorp, B. (2014). The euro crisis in metaphors and frames: Focus on the press in the Low Countries. European Journal of Communication, 29(5), 608-617. doi:10.1177/0267323114538852

Kádár, D. Z. (2007). On historical Chinese apology and its strategic application. Journal of Politeness Research, Language, Behaviour, Culture, $3(1), 125-150$.

Kal-kausar, M., Rafida, A. N., Nurulhusna, N., Alina, A., \& Mashitoh, A. S. (2013). Crisis Communication and Management on Food Recall in the Malaysian Food Industry. Middle-East Journal of Scientific Research, 13, 54-60. doi:10.5829/idosi.mejsr.2013.16.s.100210

Kartez, J. D. (1984). Crisis Response Planning Toward a Contingent Analysis. Journal of the American Planning Association, $50(1)$, 9-21.

Kash, T. J., \& Darling, J. R. (1998). Crisis management: prevention, diagnosis and intervention. Leadership \& Organization Development Journal, 19(4), 179-186.

Kauffman, J. (2000). Adding fuel to the fire: NASA's crisis communications regarding Apollo 1. Public Relations Review, $25(4), 421-432$.

Diers-Lawson, A. (2017). A state of emergency in crisis communication: An intercultural crisis communication research agenda. Journal of Intercultural Communication Research, 46(1). DOI:10.1080/17475759.2016.1262891. 
Kauffman, J. (2001). A successful failure: NASA's crisis communications regarding Apollo 13. Public Relations, 27(4), 437-449.

Kauffman, J. (2005). Lost in space: A critique of NASA's crisis communications in the Columbia disaster. Public Relations Review, 31(2), $263-275$.

Keltner, J. W. (1965). Communication and the labor-management mediation process: Some aspects and hypotheses Journal of Communication, $15(2), 64-80$.

Kenney, P. G. (1997). When a crisis occurs: A trustee's perspective. New Directions for Community Colleges, 1997(98), 73-79.

Kepplinger, H. M., \& Roth, H. (1979). Creating a Crisis: German Mass Media andOil Supply in 1973-74. Public opinion quarterly, 43(3), 285-296.

Kernisky, D. A. (1997). Proactive crisis management and ethical discourse: Dow Chemical's issues management bulletins 1979-1990. Journal of Business Ethics, 16(8), 843-853.

Ki, E.-J., \& Brown, K. A. (2013). The effects of crisis response strategies on relationship quality outcomes. Journal of Business Communication, 50(4), 403-420. doi:10.1177/0021943613497056

Ki, E.-J., \& Nekmat, E. (2014). Situational crisis communication and interactivity: Usage and effectiveness of Facebook for crisis management by Fortune 500 companies. Computers in Human Behavior, 35, 140-147. doi:http://dx.doi.org/10.1016/j.chb.2014.02.039

Kim, H.-S., \& Lee, S. Y. (2015). Testing the Buffering and Boomerang Effects of CSR Practices on Consumers' Perception of a Corporation during a Crisis. Corporate reputation review, 18(4), 277-293. doi:10.1057/crr.2015.18

Kim, J., Kim, H. J., \& Cameron, G. T. (2009). Making nice may not matter: The interplay of crisis type, response type and crisis issue on perceived organizational responsibility. Public Relations Review, 35(1), 86-88.

Kim, J., Kim, H. J., \& Cameron, G. T. (2012). Finding primary publics: A test of the third-person perception in corporate crisis situations. Journal of Public Relations Research, 24(5), 391-408.

Kim, S. (2013). Corporate ability or virtue? Relative effectivenss of prior corporate associations in times of crisis. International Journal of Strategic Communication, 7(4), 241-256. doi:10.1080/1553118X.2013.824886

Kim, S. (2013). Does corporate advertising work in a crisis? An examination of inoculation theory. Journal of Marketing Communications, 19(4), 293-305. doi:10.1080/13527266.2011.634430

Kim, S. (2014). The role of prior expectancies and relational satisfaction in crisis. Journalism \& Mass Communication Quarterly, 91(1), $139-158$. doi:10.1177/1077699013514413

Kim, S. (2014). What's worse in times of product-harm crisis? Negative corporate ability or negative CSR reputation? Journal of Business Ethics, 123(1), 157-170

Kim, S., \& Atkinson, L. J. (2014). Responses Toward Corporate Crisis and Corporate Advertising. Journal of Promotion Management, 20(5), 647665. doi:10.1080/10496491.2014.946201

Kim, S., Avery, E., \& Lariscy, R. (2009). Are crisis communicators practicing what we preach?: An evaluation of crisis response strategy analyzed in public relations research from 1991 to 2009. Public Relations Review, 35(4), 446-448. doi:10.1016/j.pubrev.2009.08.002

Kim, S., \& Choi, S. M. (2014). Is Corporate Advertising Effective in a Crisis? The Effects of Crisis Type and Evaluative Tone of News Coverage. Journal of Promotion Management, 20(2), 97-114. doi:10.1080/10496491.2013.872216

Kim, S., \& Sung, K. H. (2014). Revisiting the effectiveness of base crisis response strategies in comparison of reputation management crisis responses. Journal of Public Relations Research, 26(1), 62-78. doi:10.1080/1062726X.2013.795867

Kim, S., \& Wertz, E. K. (2013). Predictors of organizations' crisis communication approaches: Full versus limited disclosure. Public Relations Review, 39(3), 238-240. doi:http://dx.doi.org/10.1016/j.pubrev.2013.03.004

Kim, S.-Y., Choi, M.-I., Reber, B. H., \& Kim, D. (2014). Tracking public relations scholarship trends: Using semantic network analysis on PR Journals from 1975 to 2011. Public Relations Review, 40(1), 116-118. doi:http://dx.doi.org/10.1016/j.pubrev.2013.11.017

King, G. I. (2002). Crisis management and team effectiveness: A closer examination. Journal of Business Ethics, 41, $235-249$.

Klein, J., \& Dawar, N. (2004). Corporate social responsibility and consumers' attributions and brand evaluations in a product-harm crisis. International Journal of research in Marketing, 21(3), 203-217.

Kleinnijenhuis, J., Schultz, F., Utz, S., \& Oegema, D. (2013). The mediating role of the news in the BP oil spill crisis 2010: How US news is influenced by public relations and in turn influences public awareness, foreign news, and the share price. Communication Research, 408-428. doi:10.1177/0093650213510940

Kleinz, K. H. (1999). Proactive Communication in a Crisis-Driven World. School Business Affairs, 65(8), $27-31$.

Klieman, A. S. (1980). Crisis leadership and non-communication: Marcos of the philippines. Political Communication, 1(1), $43-78$.

Knight, G., \& Greenberg, J. (2002). Promotionalism and subpolitics: Nike and its labor critics. Management Communication Quarterly, 15(4), 541-570.

Koc, E. (2013). Power distance and its implications for upward communication and empowerment: Crisis management and recovery in hospitality services. The International Journal of Human Resource Management, 24(19), 3681-3696.

Koerber, D. (2014). Crisis communication response and political communities: The unusual case of Toronto mayor Rob Ford. Canadian journal of communication, 39(3).

Koesten, J., \& Rowland, R. C. (2004). The rhetoric of atonement. Communication Studies, 55, 68-88.

Korn, C., \& Einwiller, S. (2013). Media coverage about organisations in critical situations: Analysing the impact on employees. Corporate Communications: An International Journal, 18(4), 451-468. doi:http://dx.doi.org/10.1108/CCIJ-04-2012-0036

Kottasz, R., \& Bennett, R. (2014). Managing the reputation of the banking industry after the global financial crisis: Implications of public anger, processing depth and retroactive memory interference for public recall of events. Journal of Marketing Communications, 1-23. doi:10.1080/13527266.2013.871322

Kwoka, J. E. (2009). A Symposium on antitrust and the global economic crisis: The U.S. auto industry under duress: Fit or finished? Competition Policy International, 49(5), 40-72.

Lachlan, K. A., Spence, P. R., \& Lin, X. (2014). Expressions of risk awareness and concern through Twitter: on the utility of using the medium as an indication of audience needs. Computers in Human Behavior, 35, 554-559. doi:http://dx.doi.org/10.1016/j.chb.2014.02.029

Lachlan, K. A., Spence, P. R., Lin, X., \& Del Greco, M. (2014). Screaming into the wind: examining the volume and content of tweets associated with Hurricane Sandy. Communication Studies, 65(5), 500-518. doi:10.1080/10510974.2014.956941

Lachlan, K. A., Spence, P. R., Lin, X., Najarian, K. M., \& Greco, M. D. (2014). Twitter use during a weather event: comparing content associated with localized and nonlocalized hashtags. Communication Studies, 65(5), 519-534. doi:10.1080/10510974.2014.956940

Diers-Lawson, A. (2017). A state of emergency in crisis communication: An intercultural crisis communication research agenda. Journal of Intercultural Communication Research, 46(1). DOI:10.1080/17475759.2016.1262891. 
Laere, J. (2013). Wandering through crisis and everyday organizing; Revealing the subjective nature of interpretive, temporal and organizational boundaries. Journal of Contingencies and Crisis Management, 21(1), 17-25. doi:10.1111/1468-5973.12012

Lagadec, P. (1987). Communications strategies in crisis. Organization \& Environment, 1(2), 19-26.

Lalonde, C., \& Roux-Dufort, C. (2013). Challenges in Teaching Crisis Management Connecting Theories, Skills, and Reflexivity. Journal of Management Education, 37(1), 21-50. doi:10.1177/1052562912456144

Lancendorfer, K. M. (2014). Pet Food Panic: Procter and Gamble's Use of Crisis Response Advertising (CRA) in Recall Crisis. Corporate reputation review, 17(2), 94-113.

Lando, A. L. (2014). The Critical Role of Crisis Communication Plan in Corporations' Crises Preparedness and Management. Global Media Journal, 7(1), 5.

Langer, R., \& Thorup, S. (2006). Building trust in times of crisis: Storytelling and change communication in an airline company. Corporate Communications: An International Journal, 11(4), 371-390.

Lanigan, R. L. (1970). Urban crisis: Polarization and communication. Communication Studies, 21(2), 108-116.

Laufer, D., \& Coombs, W. T. (2006). How should a company respond to a product harm crisis? The role of corporate reputation and consumerbased cues. Business Horizons, 49(5), 379-385.

Lawniczak, R. (2009). Re-examining the economic roots of public relations. Public Relations Review, 35(4), 346-352. doi:10.1016/j.bbr.2011.03.031

Lazard, A. J., Scheinfeld, E., Bernhardt, J. M., Wilcox, G. B., \& Suran, M. (2015). Detecting themes of public concern: A text mining analysis of the Centers for Disease Control and Prevention's Ebola live Twitter chat. American journal of infection control, 43(10), 1109-1111. doi:10.1016/j.ajic.2015.05.025

Lee, B. K. (2004). Audience-oriented approach to crisis communication: A study of Hong Kong consumers' evaluation of an organizational crisis. Communication Research, 31(5), 600-618.

Lee, J., Jares, S. M., \& Heath, R. L. (1999). Decision-making encroachment and cooperative relationships between public relations and legal counselors in the management of organizational crisis. Journal of Public Relations Research, 11(3), 243-270.

Lee, J., Kim, S., \& Wertz, E. K. (2014). How Spokesperson Rank and Selected Media Channels Impact Perceptions in Crisis Communication. Public Relations Journal, 8(2), 2. doi:http://www.prsa.org/Intelligence/PRJournal/Vol8/No2/

Lee, K. (2009). How the Hong Kong government lost the public trust in SARS: Insights for government communication in a health crisis. Public Relations Review, 35(1), 74-76.

Lee, S., \& Chung, S. (2012). Corporate apology and crisis communication: The effect of responsibility admittance and sympathetic expression on public's anger relief. Public Relations Review, 38(5), 932-934. doi:10.1016/j.pubrev.2012.08.006

Lee, Y.-J., \& Harrald, J. R. (1999). Critical issue for business area impact analysis in business crisis management: Analytical capability. Disaster Prevention and Management: An International Journal, 8(3), 184-189.

Legg, K. L. (2009). Religious celebrity: An analysis of image repair discourse. Journal of Public Relations Research, 21(2), 240-250. doi:10.1080/1062726080255762

Len-Rios, M. E. (2010). Image Repair Strategies, Local News Portrayals and Crisis Stage: A Case Study of Duke University's Lacrosse Team Crisis. International Journal of Strategic Communication, 4(4), 267-287. doi:10.1080/1553118X.2010.515534

Leonidou, L. C., Leonidou, C. N., \& Kvasova, O. (2013). Cultural drivers and trust outcomes of consumer perceptions of organizational unethical marketing behavior. European Journal of Marketing, 47(3/4), 525-556.

Ley, B., Ludwig, T., Pipek, V., Randall, D., Reuter, C., \& Wiedenhoefer, T. (2014). Information and expertise sharing in inter-organizational crisis management. Computer Supported Cooperative Work (CSCW), 23(4-6), 347-387.

Liao, K.-S. (1980). Mass Media and Crisis Communication in China Chinese Press Reactions in the 1962 Sino-Indian Border Conflict. Communication Research, 7(1), 69-94.

Lindholm, K., \& Olsson, E.-K. (2010). Crisis communication as a multilevel game: The Muhammad cartoons from a crisis diplomacy perspective. The International Journal of Press/Politics, 16(2), 254-271.

Lipset, S. M. (1953). Opinion formation in a crisis situation. Public opinion quarterly, 17(1), 20-46.

Littlefield, R., \& Quenette, A. (2007). Crisis leadership and Hurricane Katrina: The portrayal of authority by the media in natural disasters. Journal of Applied Communication Research, 35(1), 26-47. doi:10.1080/00909880601065664

Liu, B., Austin, L., \& Jin, Y. (2011). How publics respond to crisis communication strategies:The interplay of information form and source. Public Relations Review, 37(4), 345-353. doi:10.1016/j.pubrev.2011.08.004

Liu, B., \& Pennington-Gray, L. (2015). Bed bugs bite the hospitality industry? A framing analysis of bed bug news coverage. Tourism management, 48, 33-42. doi:http://dx.doi.org/10.1016/j.tourman.2014.10.020

Liu, B., Pennington-Gray, L., Donohoe, H., \& Omodior, O. (2015). New York City bed bug crisis as framed by tourists on TripAdvisor. Tourism Analysis, 20(2), 243-250.

Liu, B. F., \& Fraustino, J. D. (2014). Beyond image repair: Suggestions for crisis communication theory development. Public Relations Review, 4O(3), 543-546. doi:http://dx.doi.org/10.1016/j.pubrev.2014.04.004

Liu, B. F., Fraustino, J. D., \& Jin, Y. (2015). How Disaster Information Form, Source, Type, and Prior Disaster Exposure Affect Public Outcomes: Jumping on the Social Media Bandwagon? Journal of Applied Communication Research, 43(1), 44-65. doi:10.1080/00909882.2014.982685

Liu, B. F., Fraustino, J. D., \& Jin, Y. (2015). Social Media Use During Disasters How Information Form and Source Influence Intended Behavioral Responses. Communication Research, 0093650214565917. doi:10.1177/0093650214565917

Liu, B. F., Jin, Y., \& Austin, L. L. (2013). The tendency to tell: Understanding publics' communicative responses to crisis information form and source. Journal of Public Relations Research, 25(1), 51-67. doi:10.1080/1062726X.2013.739101

Liu, H. (2015). Constructing the GFC: Australian banking leaders during the financial 'crisis'. Leadership, 1742715015584537. doi:10.1177/1742715015584537

Loosemore, M. (1998). The influence of communication structure upon crisis management efficiency. Construction Management and Economics, 16, 661-671.

Diers-Lawson, A. (2017). A state of emergency in crisis communication: An intercultural crisis communication research agenda. Journal of Intercultural Communication Research, 46(1). DOI:10.1080/17475759.2016.1262891. 
Loosemore, M. (1998). Reactive crisis management in construction projects: Patterns of communication and behaviour. Journal of Contingencies and Crisis Management, 6(1), 23-34.

Loosemore, M. (1998). The three ironies of crisis management in construction projects. International Journal of Project Management, 16(3), 139-144.

Loosemore, M. (1999). A grounded theory of construction crisis management. Construction Management and Economics, 17, 9-19.

Lucero, M., Kwang, A. T., \& Pang, A. (2009). Crisis leadership: When should the CEO step up? Corporate Communications: An International Journal, 14(3), 234-248.

Lukaszewski, J. E. (1997). Establishing individual and corporate crisis communication standards: The principles and protocols. Public Relations Quarterly, 42(3), 7.

Lyon, L., \& Cameron, G. T. (2004). A Relational Approach Examining the Interplay of Prior Reputation and Immediate Response to a Crisis. Journal of Public Relations Research, 16(3), 213-241. Retrieved from http://search.ebscohost.com/login.aspx?direct=true\&AuthType=ip,shib\&db=buh\&AN=13906806\&site=ehost-live

Lyu, J. C. (2012). A comparative study of crisis communication strategies between Mainland China and Taiwan: The melamine-tainted milk powder crisis in the Chinese context. Public Relations Review, 38(5), 779-791.

Lyu, J. C. (2012). How young Chinese depend on the media during public health crises? A comparative perspective. Public Relations Review, 38(5), 799-806.

Madden, S. (2015). Alerting a Campus Community: Emergency Notification from a Public's Perspective. Journal of Contingencies and Crisis Management, 23(4), 184-192. doi:10.1111/1468-5973.12074

Magen, C. (2014). Crisis communication research in Israel: A meta-analysis. Public Relations Review, 40(3), $540-542$. doi:http://dx.doi.org/10.1016/j.pubrev.2014.03.001

Maier, M., \& Messerschmidt, J. W. (1998). Commonalities, conflicts, and contradictions in organizational masculinities; Exploring the gendered genesis of the Challenger disaster. CRSA/RCSA, 35(3), 325-343.

Mallozzi, C. (1994). Facing the danger zone in crisis communications. Risk Management, 41(1), 34

Malone, P. C., \& Coombs, W. T. (2009). Introduction to special issue on crisis communication. Journal of Public Relations, 21 (2), 121-122. doi:10.1080/10627260902880006

Mao, Z. (2014). Cosmopolitanism and global risk: News framing of the Asian financial crisis and the European debt crisis. International Journal of Communication, 8, 20.

Marcus, A. A., \& Goodman, R. S. (1991). Victims and shareholders: The dilemmas of presenting corporate policy during a crisis. Academy of Management Journal, 34(2), 281-305.

Marra, F. J. (1998). Crisis communication plans: Poor predictors of excellent crisis public relations. Public Relations Review, 24(4), 461-475.

Marra, F. J. (1998). The importance of communication in excellent crisis management. Australian Journal of Emergency Management, The, $13(3), 6$.

Marsen, S. (2014). "Lock the Doors": Toward a Narrative-Semiotic Approach to Organizational Crisis. Journal of Business and Technical Communication, 1-26. doi:10.1177/1050651914524781

Martin, R. M., \& Boynton, L. A. (2005). From liftoff to landing: NASA's crisis communications and resulting media coverage following the Challenger and Columbia tragedies. Public Relations Review, 31(2), 253-261.

Martinelli, K. A., \& Briggs, W. (1998). Integrating public relations and legal responses during a crisis: The case of Odwalla, Inc. Public Relations Review, 24(4), 443-465.

Mason, A. M. (2014). The impact of media frames and treatment responsibility within the situational crisis communication theory framework. Corporate reputation review, 17(1), 78-90.

Massey, J. E. (2001). Managing organizational legitimacy: Communication strategies for organizations in crisis. The Journal of Business Communication, 38(2), 153-170.

Massey, J. E., \& Larsen, J. (2006). Crisis management in real time: How to successfully plan for and respond to a crisis. Journal of Promotion Management, 12(3/4), 63-97. doi:10.1300/J057v12n0306

Mastrandonas, A., \& Strife, P. T. (1992). Corporate environmental communications: Lessons from investors. Columbia Journal of World Business, $27(3-4), 234-241$.

Matejek, S., \& Gössling, T. (2014). Beyond legitimacy: A case study in BP's "green lashing". Journal of Business Ethics, 120(4), 571-584.

Mazer, J. P., Thompson, B., Cherry, J., Russell, M., Payne, H. J., Kirby, E. G., \& Pfohl, W. (2015). Communication in the face of a school crisis: Examining the volume and content of social media mentions during active shooter incidents. Computers in Human Behavior, 53, 238248. doi:10.1016/j.chb.2015.06.040

Mazzei, A., Kim, J.-N., \& Dell'Oro, C. (2012). Strategic value of employee relationships and communicative actions: Overcoming corporate crisis with quality internal communication. International Journal of Strategic Communication, 6(1), 31-44.

Mazzei, A., \& Ravazzani, S. (2014). Internal Crisis Communication Strategies to Protect Trust Relationships A Study of Italian Companies. International Journal of Business Communication, 1-19. doi:10.1177/2329488414525447

McClelland, C. A. (1964). Action structures and communication in two international crises: Quemoy and Berlin. Background, 7(4), 201-215.

McCoy, M. (2014). Reputational threat and image repair strategies: Northern Ireland water's crisis communication in a freeze/thaw incident. Journal of Nonprofit \& Public Sector Marketing, 26(2), 99-126. doi:10.1080/10495142.2013.872508

McDonald, L. M., \& Cokley, J. (2013). Prepare for anger, look for love: A ready reckoner for crisis scenario planners. PRism, $10(1), 1-11$.

McDonald, L. M., Sparks, B., \& Glendon, A. I. (2010). Stakeholder reactions to company crisis communication and causes. Public Relations Review, 36(3), 263-271.

McLaughlin, S. (2002). Sept. 11: Four views of crisis management. Public Relations Strategist, 8(1), 22-28. doi:105666336

Mehta, A., \& Xavier, R. (2012). Tracking the defining moments in crisis process and practice. Public Relations Review, $38,376-382$. doi:10.1016/j.pubrev.2011.12.009

Meraz, S. (2009). Is there an elite hold? Traditional media to social media agenda setting influence in blog networks. Journal of Computer Mediated Communication, 14(3), 682-707. doi:10.1111/j.1083-6101.2009.01458.x 
Metzler, M. S. (2001). Responding to the legitimacy problems of big tobacco: An analysis of the 'People of Philip Morris' image advertising campaign. Communication Quarterly, 49(4), 366-381.

Milburn, T. W., Schuler, R. S., \& Watman, K. H. (1983). Organizational crisis. Part II: Strategies and responses. Human Relations, 36(12), 11611179.

Mileti, D. S., \& Beck, E. M. (1975). Communication in crisis explaining evacuation symbolically. Communication Research, $2(1)$, $24-49$.

Miller, B. M., \& Horsley, J. S. (2009). Digging deeper: Crisis management in the coal industry. Journal of Applied Communication Research, 37(3), 298-316.

Mira, J. J., Lorenzo, S., Carrillo, I., Ferrús, L., Pérez-Pérez, P., Iglesias, F., . . Nuño-Solinís, R. (2015). Interventions in health organisations to reduce the impact of adverse events in second and third victims. BMC health services research, 15(1), 341-356. doi:10.1186/s12913015-0994-x

Mitroff, I., Alpaslan, M. C., \& Green, S. E. (2004). Crises as ill-structured messes. International Studies Review, 6(1), $165-182$.

Mitroff, I. I., Pauchant, T. C., \& Shrivastava, P. (1988). The structure of man-made organizational crises: Conceptual and empirical issues in the development of a general theory of crisis management. Technological Forecasting and Social Change, 33(2), 83-107.

Molleda, J. C., Connolly-Ahern, C., \& Quinn, C. (2005). Cross-national conflict shifting: Expanding a theory of global public relations management through quantitative content analysis. Journalism Studies, 6(1), 87-102.

Monserrat-Gauchi, J., Quiles-Soler, C., \& González-Díaz, C. (2014). Structures, Systems and Organizational Communication Processes in Franchises in times of crisis: the Spanish case. Observatorio (OBS*), 8(2), 111-122.

Moody, M. (2011). Jon and Kate Plus 8: A case study of social media and image repair tactics. Public Relations Review, 37(4), 405-414.

Moore, S. (2004). Disaster's future: The prospects for corporate crisis management and communication. Business Horizons, $47(1)$, 29-36.

Mosher, J. F. (2012). Joe Camel in a bottle: Diageo, the Smirnoff brand, and the transformation of the youth alcohol market. American Journal of Public Health, 102(1), 56-63. doi:10.2105/AJPH.2011.300387

Mou, Y., \& Lin, C. A. (2014). Communicating Food Safety via the Social Media The Role of Knowledge and Emotions on Risk Perception and Prevention. Science Communication, 36(5), 593-616. doi:10.1177/1075547014549480

Muheki, M. K., Lueg, K., Lueg, R., \& Schmaltz, C. (2014). How business reporting changed during the financial crisis: a comparative case study of two large US banks. Problems and Perspectives in Management, 12(1), 191-208.

Mukherjee, S. (2014). The Use of Twitter, Facebook, Linkedln etc. as Strategic Tools for Crisis Communication. International Journal of Management and International Business Studies, 4(2), 175-180.

Murphree, V., \& Aucoin, J. (2010). The energy crisis and the media: Mobil oil corporation's debate with the media 1973-1983. American Journalism, 27, 7-30.

Nätti, S., Rahkolin, S., \& Saraniemi, S. (2014). Crisis communication in key account relationships. Corporate Communications: An International Journal, 19(3), 234-246. doi:http://dx.doi.org/10.1108/CCIJ-08-2012-0056

Nerghes, A., Hellsten, I., \& Groenewegen, P. (2015). A toxic crisis: metaphorizing the financial Crisis. International Journal of Communication, 9, 106-132.

Nord, L. W., \& Olsson, E.-K. (2013). Frame, Set, Match! Towards a model of successful crisis rhetoric. Public Relations Inquiry, 2 (1), 79-94. doi:10.1177/2046147X12464205

Nunamaker, J. F., Weber, E. S., \& Chen, M. (1989). Organizational crisis management systems: Planning for intelligent action. Journal of management information systems, 5(4), 7-31.

Nwankwo, R. N. (1971). Communication in campus crisis: a study of symbolic interaction. Journalism \& Mass Communication Quarterly, 48(3), 438-446.

O'Mara-Shimek, M., Guillén-Parra, M., \& Ortega-Larrea, A. (2015). Stop the bleeding or weather the storm? crisis solution marketing and the ideological use of metaphor in online financial reporting of the stock market crash of 2008 at the New York Stock Exchange. Discourse \& Communication, 9(1), 103-123. doi: 10.1177/1750481314556047

Oles, D. L. (2010). Deny, delay, apologize: The Oprah Winfrey image-defense playbook. Northwest Journal of Communication, 39(1), 37-63.

Oliveira, M., \& Murphy, P. (2009). The leader as the face of a crisis: Philip Morris' CEO's speeches during the 1990's. Public Relations Research, 21(4), 361-380.

Olofsson, A. (2007). Crisis communication in multicultural societies: A study of municipalities in Sweden. International journal of mass emergencies and disasters, 25(2), 145-172.

Olsson, E.-K. (2013). Public diplomacy as a crisis communication tool. Journal of International Communication, 19(2), $219-234$. doi:10.1080/13216597.2013.838906

Olsson, E. K. (2014). Crisis communication in public organisations: Dimensions of crisis communication revisited. Journal of Contingencies and Crisis Management, 22(2), 113-125.

Olsson, E.-K., Nord, L. W., \& Falkheimer, J. (2015). Media coverage crisis exploitation characteristics: A case comparison study. Journal of Public Relations Research, 27(2), 158-174. doi:10.1080/1062726X.2014.976827

Ott, L., \& Theunissen, P. (2015). Reputations at risk: Engagement during social media crises. Public Relations Review, 41(1), 97-102. doi:http://dx.doi.org/10.1016/j.pubrev.2014.10.015

Pace, K., Fediuk, T. A., \& Botero, I. C. (2009). The acceptance of responsibility and expressions of regret in organizational apologies after a transgression. Corporate Communications: An International Journal, 15(4), 410-427. doi:10.1108/13563281011085510

Pace, S., Balboni, B., \& Gistri, G. (2014). The effects of social media on brand attitude and WOM during a brand crisis: Evidences from the Barilla case. Journal of Marketing Communications, 1-14. doi:10.1080/13527266.2014.966478

Page, R. (2014). Saying 'sorry': Corporate apologies posted on Twitter. Journal of Pragmatics, 62, 30-45. doi:http://dx.doi.org/10.1016/j.pragma.2013.12.003

Palazzo, G., \& Scherer, A. G. (2006). Corporate legitimacy as a deliberation: A communicative framework. Journal of Business Ethics, 667(1), 7188. doi:10.1007/s10551-006-9044-2

Palen, L., Vieweg, S., Liu, S. B., \& Hughes, A. L. (2009). Crisis in a networked world features of computer-mediated communication in the April 16, 2007, Virginia Tech Event. Social Science Computer Review, 27(4), 467-480. 
Palmer, A., Irlbeck, E., Myers, C., \& Chambers, T. (2013). A case study of the risk and crisis communications used in the 2008 Salmonella outbreak. Journal of Applied Communications, 97(1), 38-50.

Palmer-Silveira, J. C., \& Ruiz-Garrido, M. F. (2014). Examining US and Spanish Annual Reports Crisis Communication. Business and Professional Communication Quarterly, 1-17. doi:10.1177/2329490614543176

Pang, A., Begam Binte Abul Hassan, N., \& Chee Yang Chong, A. (2014). Negotiating crisis in the social media environment: Evolution of crises online, gaining credibility offline. Corporate Communications: An International Journal, 19(1), 96-118. doi:http://dx.doi.org/10.1108/CCIJ-09-2012-0064

Pang, A., Cropp, F., \& Cameron, G. T. (2006). Corporate crisis planning: Tensions, issues, and contradictions. Journal of Communication Management, 10(4), 371-389.

Pang, A., Frandsen, F., Johansen, W., \& Yeo, S. L. (2013). A comparative study of crisis consultancies between Singapore and Denmark: distant cousins of the same destiny? International Journal of Strategic Communication, 7(2), 149-164. doi:http://dx.doi.org/10.1080/1553118X.2013.765880

Papadakis, V. M., Kaloghirou, Y., \& latrelli, M. (1999). Strategic decision making: From crisis to opportunity. Business Strategy Review, 10(1), 2937.

Paquette, M. (2015). Renewal or Re-Entrenchment? A Case Study of 2011 Education Union Crisis. Journal of Public Relations Research, 27(4), 337-352. doi:10.1080/1062726X.2015.1060130

Paraskevas, A., \& Altinay, L. (2013). Signal detection as the first line of defence in tourism crisis management. Tourism management, 34, 158171. doi:10.1016/j.tourman.2012.04.007

Paraskevas, A., Altinay, L., McLean, J., \& Cooper, C. (2013). Crisis knowledge in tourism: Types, flows and governance. Annals of Tourism Research, 41, 130-152. doi:http://dx.doi.org/10.1016/j.annals.2012.12.005

Park, H., \& Cameron, G. T. (2014). Keeping It Real Exploring the Roles of Conversational Human Voice and Source Credibility in Crisis Communication via Blogs. Journalism \& Mass Communication Quarterly, 1077699014538827. doi:10.1177/1077699014538827

Park, S.-A. (2008). Consumer health crisis management: Apple's crisis responsibility for iPod-related hearing loss. Public Relations Review, 34(4), 396-398.

Parmenter, D. (2010). Crisis leadership: 10 lessons from Sir Shackleton. Leadership Excellence, $27(6), 6$.

Parnell, J. A. (2015). Crisis Management and Strategic Orientation in Small and Medium-Sized Enterprises (SMEs) in Peru, Mexico and the United States. Journal of Contingencies and Crisis Management, 23(4), 221-233. doi:http://dx.doi.org/10.1111/1468-5973.12060

Pauchant, T. C., \& Mitroff, I. I. (1990). Crisis management: Managing paradox in a chaotic world. Technological Forecasting and Social Change, 38(2), 117-134

Paul, J., \& Strbiak, C. A. (1997). The ethics of strategic ambiguity. Journal of Business Communication, 34(2), $149-159$.

Payne, L. L. (2006). Synthesizing crisis communication and reputation management: An experimental examination of memory. Journal of Promotion Management, 12(3-4), 161-187.

Pearson, C. M., \& Clair, J. A. (1998). Reframing crisis management. Academy of Management Review, 23(1), 58-76.

Pearson, C. M., \& Mitroff, I. (1993). From crisis prone to crisis prepared: A framework for crisis management. Academy of Management Executive, 7(1), 48-59.

Peijuan, C., Ting, L., \& Pang, A. (2009). Managing a nation's image during crisis: A study of the Chinese government's image repair efforts in the "Made in China" controversy. Public Relations Review, 35(3), 213-218.

Pennington-Gray, L., Kaplanidou, K., \& Schroeder, A. (2013). Drivers of social media use among African Americans in the event of a crisis. Natural Hazards, 66(1), 77-95. doi:10.1007/s11069-012-0101-0

Penrose, J. M. (2000). The role of perception in crisis planning. Public Relations Review, 26(2), $155-171$.

Perreault, M. F., Houston, J. B., \& Wilkins, L. (2014). Does scary matter?: Testing the effectiveness of new National Weather Service tornado warning messages. Communication Studies, 65(5), 484-499. doi:10.1080/10510974.2014.956942

Perry, D. C., Taylor, M., \& Doerfel, M. L. (2003). Internet-based communication in crisis management. Management Communication Quarterly, 17(2), 206-232.

Phelps, N. L. (1986). Setting up a crisis recovery plan. Journal of Business Strategy, 6(4), 5-10.

Pines, W. L. (2000). Myths of crisis management. Public Relations Quarterly, 45(3), 15-17.

Ping, Q., Ishaq, M., \& Li, C. (2015). Product Harm Crisis, Attribution of Blame and Decision Making: An Insight from the Past. Journal of Applied Environmental and Biological Sciences, 5(5), 35-44.

Piotrowski, C., \& Guyette, R. W. (2010). Toyota recall crisis: Public attitudes on leadership and ethics. Organizational Development Journal, $28(2), 89-97$.

Pollock, J. C., Guidette, C. L., \& Nimmo, D. (1980). Mass media, crisis and political change: a cross-national approach. Communication yearbook IV, 309-324.

Preble, J. F. (1997). Integrating the crisis management perspective into the strategic management process. Journal of management studies, 34(5), 769-791.

Procter, R., Vis, F., \& Voss, A. (2013). Reading the riots on Twitter: methodological innovation for the analysis of big data. International journal of social research methodology, 16(3), 197-214.

Promsri, C. (2014). Thai employees' perception towards organizational crisis preparedness. Mediterranean Journal of Social Sciences, $5(14)$, 41. doi:10.5901/mjss.2014.v5n14p41

Purohit, H., Hampton, A., Bhatt, S., Shalin, V. L., Sheth, A. P., \& Flach, J. M. (2014). Identifying seekers and suppliers in social media communities to support crisis coordination. Computer Supported Cooperative Work (CSCW), 23(4-6), 513-545.

Quarantelli, E. L. (1988). Disaster crisis management: A summary of research findings. Journal of management studies, 25(4), 373-385.

Quarantelli, E. L., \& Dynes, R. R. (1977). Response to social crisis and disaster. Annual review of sociology, 23-49.

Quirke, B. (2009). Steering leaders out of a crisis using effective communication. Strategic Communication Management, $14(1)$, 24-27. doi:1930082341

Rafter, K. (2014). Voices in the crisis: The role of media elites in interpreting Ireland's banking collapse. European Journal of Communication, 110. doi:10.1177/0267323114537787

Diers-Lawson, A. (2017). A state of emergency in crisis communication: An intercultural crisis communication research agenda. Journal of Intercultural Communication Research, 46(1). DOI:10.1080/17475759.2016.1262891. 
Ramsay, C. G. (1999). Protecting your business: from emergency planning to crisis management. Journal of Hazardous Materials, 65(1), 131149.

Rasmussen, R. K., \& Merkelsen, H. (2014). The risks of nation branding as crisis response: A case study of how the Danish government turned the Cartoon Crisis into a struggle with Globalization. Place Branding and Public Diplomacy, 10(3), 230-248.

Ratzan, S. C., \& Moritsugu, K. P. (2014). Ebola crisis-communication chaos we can avoid. Journal of Health Communication, $19(11)$, $1213-1215$. doi:10.1080/10810730.2014.977680

Reierson, J. L., Sellnow, T. L., \& Ulmer, R. R. (2009). Complexities of crisis renewal over time: Learning from the tainted Odwalla apple juice case. Communication Studies, 60(2), 114-129. doi:10.1080/10510970902834841

Reilly, A. (1987). Are organisations ready for a crisis? Columbia Journal of World Business, 79-87.

Reilly, A. H. (2008). The role of human resource development competencies in facilitating effective crisis communication. Advances in Developing Human Resources, 10(3), 331-351.

Renkema, J., \& Hoeken, H. (1998). The influence of negative newspaper publicity on corporate image in the Netherlands. The Journal of Business Communication, 35(4), NA.

Reynolds, B., \& Quinn, S. C. (2008). Effective communication during an influenza pandemic: the value of using a crisis and emergency risk communication framework. Health promotion practice, 9(4 suppl), 13S-17S.

Reynolds, B., \& Seeger, M. W. (2005). Crisis and emergency risk communication as an integrative model. Journal of Health Communication, $10(1), 43-55$.

Rhee, H. T., \& Yang, S.-B. (2014). Consumers' Emotional Reactions to Negative Publicity and Crisis Management in the Health Care Industry A Multiple Case Study of Lipitor and Oxyelite Pro. Social Science Computer Review, 32(5), 678-693. doi:10.1177/0894439314525901

Rickard, L. N., McComas, K. A., Clarke, C. E., Stedman, R. C., \& Decker, D. J. (2013). Exploring risk attenuation and crisis communication after a plague death in Grand Canyon. Journal of Risk Research, 16(2), 145-167. doi:10.1080/13669877.2012.725673

Riddell, P. (2013). Rallying the troops: Crisis communication and reputation management in financial services. Journal of Brand Strategy, 2(3), 222-227.

Ritchie, B. W. (2004). Chaos, crises and disasters: a strategic approach to crisis management in the tourism industry. Tourism management, 25(6), 669-683.

Roberts, B. W., \& Donahue, E. M. (1994). One personality, multiple selves: Integrating personality and social roles. Journal of Personality, 62, 199-218. doi:10.1111/j.1467-6494.1994.tb00291.x

Robertson, A. (2014). Atlas reports: Global television constructions of economic crisis. European Journal of Communication, 1-8. doi:10.1177/0267323114535884

Roca, B. (2015). Development Discourse under the Economic Crisis: An Analysis of the Communication Strategy of Spanish NGO. Anthropologist, $19(2), 431-439$.

Rogan, R. G., \& Hammer, M. R. (1995). Assessing message affect in crisis negotiations: An exploratory study. Human Communication Research, 21(4), 553-574.

Romenti, S., Murtarelli, G., \& Valentini, C. (2014). Organisations' conversations in social media: applying dialogue strategies in times of crises. Corporate Communications: An International Journal, 19(1), 10-33. doi:10.1108/CCIJ-05-2012-0041

Romenti, S., \& Valentini, C. (2010). Alitalia's crisis in the media - a situational analysis. Corporate Communications: An International Journal, 15(4), 380-396. doi:2241134491

Rosenthal, U., \& Kouzmin, A. (1991). The bureau-politics of crisis management. Public Administration, 69(2), $211-233$.

Ross, D. L., \& Benson, J. A. (1995). Cultural change in ethical redemption: A corporate case study. The Journal of Business Communication, 32(4), $345-362$.

Roux-Dufort, C. (2000). Why organizations don't learn from crises: The perverse power of normalization. Review of Business, 25 -30.

Rovisco, M. (2010). One Europe or several Europes? The cultural logic of narratives of Europe views from France and Britain Social Science Information, 49(2), 241-266. doi:10.1177/0539018409359844

Ruggiero, A., \& Vos, M. (2013). Terrorism communication: characteristics and emerging perspectives in the scientific literature $2002-2011$. Journal of Contingencies and Crisis Management, 21(3), 153-166. doi:10.1111/1468-5973.12022

Ruggiero, A., \& Vos, M. (2015). Communication Challenges in CBRN Terrorism Crises: Expert Perceptions. Journal of Contingencies and Crisis Management, 23(3), 138-148. doi:10.1111/1468-5973.12065

Rutsaert, P., Pieniak, Z., Regan, Á., McConnon, Á., Kuttschreuter, M., Lores, M., . . Verbeke, W. (2014). Social media as a useful tool in food risk and benefit communication? A strategic orientation approach. Food policy, 46, 84-93. doi:http://dx.doi.org/10.1016/j.foodpol.2014.02.003

Rutsaert, P., Regan, Á., Pieniak, Z., McConnon, Á., Moss, A., Wall, P., \& Verbeke, W. (2013). The use of social media in food risk and benefit communication. Trends in Food Science \& Technology, 30(1), 84-91.

Saliou, P. (1994). Crisis communication in the event of a flu pandemic. European journal of epidemiology, $10(4), 515-517$.

Samansky, A. W. (2002). RUN!: That's not the crisis communications plan you need. Public Relations Quarterly, 47(3), 25-27. doi:208286241

Samaraweera, G. C., Li, C., \& Qing, P. (2014). Mitigating Product Harm Crises and Making Markets Sustainable: How does National Culture Matter? Sustainability, 6(5), 2642-2657.

Samkin, G., Allen, C., \& Wallace, K. (2010). Repairing Organisational Legitimacy: the Case of the New Zealand Police. Australasian Accounting Business \& Finance Journal, 4(3), 23-45. doi:2170715441

Sanderson, J., \& Emmons, B. (2014). Extending and Withholding Forgiveness to Josh Hamilton Exploring Forgiveness Within Parasocial Interaction. Communication \& Sport, 2(1), 24-47. doi:10.1177/2167479513482306

Sandler, C. (2009). The psychological role of the leader in turbulent times. Strategic HR Review, 8(3), 30-35.

Sandman, P. M. (2006). Crisis communication best practices: Some quibbles and additions. Journal of Applied Communication Research, 34(3), 257-262.

Sarlos, G., \& Szondi, G. (2015). Crisis communication during the red sludge spill disaster in Hungary-a media content analysis-based investigation. Journal of Public Affairs, 15(3), 277-286. doi:10.1002/pa.1526 
Schmidt, V. A. (2014). Speaking to the markets or to the people? A discursive institutionalist analysis of the EU's sovereign debt crisis. The British Journal of Politics and International Relations, 16(1), 188-209. doi:10.1111/1467-856X.12023

Scholtens, A., Jorritsma, J., \& Helsloot, I. (2014). On the Need for a Paradigm Shift in the Dutch Command and Information System for the Acute Phase of Disasters. Journal of Contingencies and Crisis Management, 22(1), 39-51. doi:10.1111/1468-5973.12035

Schroeder, A., \& Pennington-Gray, L. (2015). The role of social media in international tourist's decision making. Journal of Travel Research, 54(5), 584-595. doi:10.1177/0047287514528284

Schroeder, A., Pennington-Gray, L., \& Bricker, K. (2014). Lessons Learnt from the Westgate Shopping Mall Terrorist Attack in Nairobi, Kenya: Involving the Meetings, Incentives, Conferences and Exhibitions Sector in Crisis Communications. International Journal of Religious Tourism and Pilgrimage, 2(1), 6. doi:http://arrow.dit.ie/ijrtp/vol2/iss1/6

Schroeder, A., Pennington-Gray, L., Donohoe, H., \& Kiousis, S. (2013). Using social media in times of crisis. Journal of Travel \& Tourism Marketing, 30(1-2), 126-143. doi:10.1080/10548408.2013.751271

Schultz, F., Kleinnijenhuis, J., Oegema, D., Utz, S., \& van Atteveldt, W. (2012). Strategic framing in the BP crisis: A semantic network analysis of associative frames. Public Relations Review, 38, 97-107. doi:10.1016/j.pubrev.2011.08.003

Schultz, F., Utz, S., \& Göritz, A. (2011). Is the medium the message? Perceptions of and reactions to crisis communication via twitter, blogs and traditional media. Public Relations Review, 37(1), 20-27. doi:10.1016/j.pubrev.2010.12.001

Schwartz, N. D. (2006). Can BP bounce back? Fortune, 154(8), 90-99.

Schwartz, S., \& Ben David, A. (1976). Responsibility and helping in an emergency: Effects of blame, ability and denial of responsibility. Sociometry, 406-415.

Schwarz, A. (2008). Covariation-based causal attributions during organizational crises: Suggestions for extending Situational Crisis Communication Theory (SCCT). International Journal of Strategic Communication, 2(1), 31-53.

Schweiger, D. M., \& Denisi, A. S. (1991). Communication with employees following a merger: A longitudinal field experiment. Academy of Management Journal, 34(1), 110-135.

Scott, D., Brandow, C., Hobbins, J., Nilsson, S., \& Enander, A. (2015). Capturing the citizen perspective in crisis management exercises: possibilities and challenges. International Journal of Emergency Services, 4(1), 86-102. doi:10.1108/IJES-12-2014-0024

Seeger, M., \& Ulmer, R. R. (2002). A post-crisis discourse of renewal: The cases of Malden Mills and Cole Hardwoods. Journal of Applied Communication Research, 30(2), 126-142.

Seeger, M. W. (2002). Chaos and crisis: Propositions for a general theory of crisis communication. Public Relations Review, $28,329-337$.

Seeger, M. W. (2006). Best practices in crisis communication: An expert panel process. Journal of Applied Communication Research, 34(3), 232244.

Seeger, M. W., \& Griffin-Padgett, D. R. (2010). From image restoration to renewal: Approaches to understanding postcrisis communication. The Review of Communication, 10(2), 127-141. doi:10.1080/1535859090354526

Seeger, M. W., Heyart, B., Barton, E. A., \& Bultnyck, S. (2001). Crisis planning and crisis communication in the public schools: Assessing post Columbine responses. Communication Research Reports, 18(4), 375-383.

Sellnow, D. D., Lane, D., Littlefield, R. S., Sellnow, T. L., Wilson, B., Beauchamp, K., \& Venette, S. (2015). A receiver-based approach to effective instructional crisis communication. Journal of Contingencies and Crisis Management, 23(3), 149-158. doi:10.1111/1468-5973.12066

Sellnow, D. D., \& Sellnow, T. L. (2014). The challenge of exemplification in crisis communication. Journal of Applied Communications, 98(2), 5365.

Sellnow, T., \& Sarabakhsh, M. (1999). Crisis management in the hospitality industry. Hospitality Review, $17(1), 6$.

Sellnow, T. L. (1993). Scientific argument in organizational crisis communication: The case of Exxon. Argumentation and Advocacy, 30(1), 28-43.

Sellnow, T. L., \& Brand, J. D. (2001). Establishing the structure of reality for an industry: Model and anti-model arguments as advocacy in Nike's crisis communication. Journal of Applied Communication Research, 29(3), 278-296.

Sellnow, T. L., \& Seeger, M. (2001). Exploring the boundaries of crisis communication: The case of the 1997 Red River Valley flood. Communication Studies, 52(2), 153-168.

Sellnow, T. L., Seeger, M. W., \& Ulmer, R. R. (2002). Chaos theory, informational needs, and natural disasters. Journal of Applied Communication Research, 30(4), 269-292.

Sellnow, T. L., \& Ulmer, R. R. (1995). Ambiguous argument as advocacy in organizational crisis communication. Argumentation and Advocacy, 31(3), 138-151.

Sellnow, T. L., Ulmer, R. R., \& Snider, M. (1998). The compatibility of corrective action in organizational crisis communication. Communication Quarterly, 46(1), 60-74.

Servaes, J. (1991). European press coverage of the Grenada crisis. Journal of Communication, 41(4), 28-41.

Shan, L., Regan, Á., De Brún, A., Barnett, J., van der Sanden, M. C., Wall, P., \& McConnon, Á. (2013). Food crisis coverage by social and traditional media: A case study of the 2008 Irish dioxin crisis. Public Understanding of Science, 0963662512472315.

Shaw, F., Burgess, J., Crawford, K., \& Bruns, A. (2013). Sharing news, making sense, saying thanks. Australian Journal of Communication, 40(1), 23.

Sheaffer, Z., Richardson, B., \& Rosenblatt, Z. (1998). Early-warming-signals management: A lesson from the Barings Crisis. Journal of Contingencies and Crisis Management, 6(1), 1-22.

Shenhar, G. (2014). Crisis communication saved lives in Israel. Frontiers in public health, 2. doi:10.3389/fpubh.2014.00222

Shepard, R. (2009). Toward a theory of simulated atonement: A case study of President George W. Bush's response to the Abu Ghraib torture scandal. Communication Studies, 60(5), 460-475. doi:10.1080/10510970903260319

Shifflet, M., \& Brown, J. (2006). The use of instructional simulations to support classroom teaching: A crisis communication case study. Journal of Educational Multimedia and Hypermedia, 15(4), 377.

Siehl, C., Smith, D., \& Omura, A. (1990). After the merger: should executives stay or go? The Executive, 50-60.

Simcic Brønn, P. (2014). How others see us: leaders' perceptions of communication and communication managers. Journal of Communication Management, 18(1), 58-79. doi:http://dx.doi.org/10.1108/JCOM-03-2013-0028

Simola, S. (2003). Ethics of justice and care in corporate crisis management. Journal of Business Ethics, 46(4), $351-361$.

Simola, S. (2005). Concepts of care in organizational crisis prevention. Journal of Business Ethics, 62, 341-353. doi:10.1007/s10551-005-3069-9

Diers-Lawson, A. (2017). A state of emergency in crisis communication: An intercultural crisis communication research agenda. Journal of Intercultural Communication Research, 46(1). DOI:10.1080/17475759.2016.1262891. 
Simola, S. (2014). Teaching corporate crisis management through business ethics education. European Journal of Training and Development, 38(5), 483-503. doi:http://dx.doi.org/10.1108/EJTD-05-2013-0055

Simon, T., Goldberg, A., Aharonson-Daniel, L., Leykin, D., \& Adini, B. (2014). Twitter in the cross fire-the use of social media in the westgate mall terror attack in Kenya. PloS one, 9(8), e104136. doi:http://dx.doi.org/10.1371/journal.pone.0104136

Singer, L. W., \& Reber, J. (1977). A New Way to Face Terrorists: A Crisis Management System. Security Management, 21(5), 6-9.

Siomkos, G., \& Shrivastava, P. (1993). Responding to product liability crises. Long Range Planning, 26(5), 72-79.

Sisco, H. F., Collins, E. L., \& Zoch, L. M. (2010). Through the looking glass: A decade of Red Cross crisis response and situational crisis communication theory. Public Relations Review, 36(1), 21-27.

Sjöberg, E., Barker, G. C., Landgren, J., Griberg, I., Skiby, J. E., Tubbin, A., . . Knutsson, R. (2013). Social media and its dual use in biopreparedness: Communication and visualization tools in an animal bioterrorism incident. Biosecurity and bioterrorism: biodefense strategy, practice, and science, $11(\mathrm{~S} 1)$, S264-S275.

Slabbert, Y., \& Barker, R. (2014). Towards a new model to describe the organisation-stakeholder relationship-building process: A strategic corporate communication perspective. Communicatio, 40(1), 69-97. doi:10.1080/02500167.2014.875481

Slavkovikj, V., Verstockt, S., Van Hoecke, S., \& Van de Walle, R. (2014). Review of wildfire detection using social media. Fire safety journal, 68, 109-118. doi:http://dx.doi.org/10.1016/j.firesaf.2014.05.021

Sly, T. (2000). Communicating about risks: A checklist for health agencies. Environmental Health, 33-35

Smart, C., \& Vertinsky, I. (1977). Designs for crisis decision units. Administrative science quarterly, 640-657.

Smith, B. L. (1956). Trends in Research on International Communication and Opinion, 1945-55. The Public Opinion Quarterly, $20(1), 182-195$.

Smith, D. (1990). Beyond contingency planning: Towards a model of crisis management. Organization \& Environment, 4(4), $263-275$.

Smith, D., \& McCloskey, J. (1998). Risk and crisis management in the public sector: risk communication and the social amplification of public sector risk. Public Money and Management, 18(4), 41-50.

Smithson, J., \& Venette, S. (2013). Stonewalling as an image-defense strategy: A critical examination of BP's response to the Deepwater Horizon explosion. Communication Studies, 64(4), 395-410. doi:10.1080/10510974.2013.770409

Snellen, M. (2003). Crisis web sites. Strategic HR Review, 2(3), 4.

Snoeijers, E. M., Poels, K., \& Nicolay, C. (2014). \# universitycrisis The Impact of Social Media Type, Source, and Information on Student Responses Toward a University Crisis. Social Science Computer Review, 0894439314525025. doi:10.1177/0894439314525025

Sohn, Y., \& Lariscy, R. W. (2014). Understanding reputational crisis: Definition, properties, and consequences. Journal of Public Relations Research, 26(1), 23-43. doi:10.1080/1062726X.2013.795865

Sönmez, S. F., Apostolopoulos, Y., \& Tarlow, P. (1999). Tourism in crisis: Managing the effects of terrorism. Journal of Travel Research, 38(1), 1318.

Spaeth, M. (2010). BP's oil spill: Eight lessons for leaders. Leadership Excellence, 27(10), 19.

Spence, P. R., Lachlan, K. A., Lin, X., \& del Greco, M. (2015). Variability in Twitter content across the stages of a natural disaster: Implications for crisis communication. Communication Quarterly, 63(2), 171-186. doi:10.1080/01463373.2015.1012219

Spence, P. R., Lachlan, K. A., Lin, X., Sellnow-Richmond, D. D., \& Sellnow, T. L. (2015). The Problem with Remaining Silent: Exemplification Effects and Public Image. Communication Studies, 66(3), 341-357. doi:10.1080/10510974.2015.1018445

Spence, P. R., Lachlan, K. A., Omilion-Hodges, L. M., \& Goddard, A. K. (2014). Being first means being credible? Examining the impact of message source on organizational reputation. Communication Research Reports, 31(1), 124-130. doi:10.1080/08824096.2013.846259

Spence, P. R., Lachlan, K. A., Westerman, D., \& Spates, S. A. (2013). Where the gates matter less: Ethnicity and perceived source credibility in social media health messages. Howard Journal of Communications, 24(1), 1-16.

Spitzer, S. P., \& Denzin, N. K. (1965). Levels of knowledge in an emergent crisis. Social forces, 44(2), $234-237$.

Sriraj, P. S., \& Khisty, C. J. (1999). Crisis management and planning using systems methodologies. Journal of Urban Planning and Development, 121-133.

Stallings, R. A. (1989). Volunteerism inside complex organizations: Off-duty hospital peronnel in a disaster. Nonprofit and Voluntary Sector Quarterly, 18(2), 133-145.

Steelman, T. A., \& McCaffrey, S. (2013). Best practices in risk and crisis communication: Implications for natural hazards management. Natural Hazards, 65(1), 683-705.

Stephens, K., Malone, P. C., \& Bailey, C. (2005). Communicating with stakeholders during a crisis. Journal of Business Communication, 42(4), 390-419. doi:10.1177/0021943605279057

Stephens, K. K., Barrett, A. K., \& Mahometa, M. J. (2013). Organizational communication in emergencies: Using multiple channels and sources to combat noise and capture attention. Human Communication Research, 39(2), 230-251. doi:10.1111/hcre.12002

Stevens, B. (1999). Persuasion, probity, and paltering: The Prudential crisis. Journal of Business Communication, 36(4), 319-334.

Stone, M., Erickson, S. L., \& Thorwick, M. (2015). An Examination of Pfizer's Crisis Communication Strategies in the Celebrex Case. American Journal of Management, 15(1), 11.

Strother, J. B. (2004). Crisis communication put to the test: The case of two airlines on 9/11. Professional Communication, IEEE Transactions on, 47(4), 290-300.

Stuart, S. Y., \& Cohen, L. (2010). Managing the Message in Real Time: Crisis Communication in the Instant-Information Age. American Bankruptcy Institute Journal, 29(9), 24, 75-76. doi:2195783881

Sturges, D. L., Carrell, B. J., Newsom, D. A., \& Barrera, M. (1991). Crisis communication management: The public opinion node and its relationship to environmental nimbus. SAM Advanced Management Journal, 56(3), 22-27.

Sung, M., \& Hwang, J.-S. (2014). Who drives a crisis? The diffusion of an issue through social networks. Computers in Human Behavior, 36, 246257. doi:http://dx.doi.org/10.1016/j.chb.2014.03.063

Sung-Un, Y., Minjeong, K., \& Johnson, P. (2010). Effects of narratives, openness to dialogic communication, and credibility on engagement in crisis communication through organizational blogs. Communication Research, 37(4), 473-497. doi:10.1177/0093650210362682

Susaeta, L., Suarez, E., \& Pin, J. R. (2013). Economic crisis and communication: The role of the HR manager. Business Systems Review, 2(2), 278296. doi:10.7350/BSR.V14.2013

Diers-Lawson, A. (2017). A state of emergency in crisis communication: An intercultural crisis communication research agenda. Journal of Intercultural Communication Research, 46(1). DOI:10.1080/17475759.2016.1262891. 
Sutton, J., League, C., Sellnow, T. L., \& Sellnow, D. D. (2015). Terse messaging and public health in the midst of natural disasters: The case of the Boulder floods. Health communication, 30(2), 135-143. doi:10.1080/10410236.2014.974124

Sutton, J., Spiro, E. S., Johnson, B., Fitzhugh, S., Gibson, B., \& Butts, C. T. (2014). Warning tweets: Serial transmission of messages during the warning phase of a disaster event. Information, Communication \& Society, 17(6), 765-787. doi:10.1080/1369118X.2013.862561

Svensson, P. (2009). Embracing left and right image repair and crisis communication in a polarized ideological milieu. Management Communication Quarterly, 22(4), 555-576.

Sweetser, K. D., \& Metzgar, E. (2007). Communicating during crisis: Use of blogs as a relationship management tool. Public Relations Review, 33(3), 340-342.

't Hart, P. (1993). Symbols, rituals and power: The lost dimensions of crisis management. Journal of Contingencies and Crisis Management, 1(1), 36-50.

't Hart, P. (1997). Preparing policy makers for crisis management: The role of simulations. Journal of Contingencies and Crisis Management, 5(4), 207-215.

Takahashi, B., Tandoc, E. C., \& Carmichael, C. (2015). Communicating on Twitter during a disaster: An analysis of tweets during Typhoon Haiyan in the Philippines. Computers in Human Behavior, 50, 392-398. doi:http://dx.doi.org/10.1016/j.chb.2015.04.020

Takamatsu, M. (2014). The Okinawa Tourism Crisis Management Initiatives. International Journal of Event Management Research, 8(1), $19-34$.

Taneja, S., Pryor, M. G., Sewell, S., \& Recuero, A. M. (2014). Strategic Crisis Management: A Basis for Renewal and Crisis Prevention. Journal of Management Policy and Practice, 15(1), 78.

Tanifuji, E. (2000). Crisis awareness and organizational response capabilities in present Japanese local governments: Crisis awareness survey findings. Journal of Contingencies and Crisis Management, 8(1), 30-41.

Taylor, M. (2000). Cultural variance as a challenge to global public relations: A case study of the Coca-Cola scare in Europe. Public Relations Review, 26(3), 277-293.

Taylor, M., \& Perry, D. C. (2005). Diffusion of traditional and new media tactics in crisis communication. Public Relations Review, 31(2), $209-217$.

Theus, K. T. (1988). Organizational response to media reporting. Public Relations Review, 14(4), 45-58.

Tipuric, D., Skoko, B., Jugo, D., \& Mesin, M. (2013). Crisis Management Dilemmas: Differences In Attitudes Towards Reactive Crisis Communication Strategies Among Future Business Professionals In Croatia. Montenegrin Journal of Economics, 9(2), 27.

Tjosvold, D. (1984). Effects of crisis orientation on managers' approach to controversy in decision making. Academy of Management Journal, $27(1), 130-138$.

Touri, M., \& Rogers, S. L. (2013). Europe's Communication Deficit and the UK Press: Framing the Greek Financial Crisis. Journal of Contemporary European Studies, 21(2), 175-189. doi:10.1080/14782804.2013.815462

Trettin, L., \& Musham, C. (2000). Is trust a realistic goal of environmental risk communication? Environment and Behavior, 32(3), 410-427.

Trujillo, N., \& Toth, E. L. (1987). Organizational perspectives for public relations research and practice. Management Communication Quarterly, $1(2), 199-281$.

Turk, J. V., Jin, Y., Stewart, S., Kim, J., \& Hipple, J. R. (2012). Examining the interplay of an organization's prior reputation, CEO's visibility, and immediate response to a crisis. Public Relations Review, 38(4), 574-583. doi:http://dx.doi.org/10.1016/j.pubrev.2012.06.012

Turner, P. (1999). When the talking gets tough: Communicating during a crisis. Journal of Property Management, 30-31.

Tyler, L. (1997). Liability means never being able to say you're sorry: Corporate guilt, legal constraints, and defensiveness in corporate communication. Management Communication Quarterly, 11(1), 51-73. doi:10.1177/0893318997111003

Tyler, L. (2005). Towards a postmodern understanding of crisis communication. Public Relations Review, 31(4), 566-571.

Ucelli, L. (2002). The CEO's “how to” guide to crisis communications. Strategy and Leadership, 30(2), 21-24.

Uddin, S., Hamra, J., \& Hossain, L. (2013). Exploring communication networks to understand organizational crisis using exponential random graph models. Computational and Mathematical Organization Theory, 19(1), 25-41. doi:10.1007/s10588-011-9104-8

Ulmer, R. R. (2001). Effective crisis management through established stakeholder relationships: Malden Mills as a case study. Management Communication Quarterly, 14(4), 590-615.

Ulmer, R. R., Seeger, M. W., \& Sellnow, T. L. (2007). Post-crisis communication and renewal: Expanding the parameters of post-crisis discourse. Public Relations Review, 33(2), 130-134. doi:10.1016/j.pubrev.2006.11.015

Ulmer, R. R., \& Sellnow, T. L. (1997). Strategic ambiguity and the ethic of significant choice in the tobacco industry's crisis communication. Communication Studies, 48(3), 215-233.

Ulmer, R. R., \& Sellnow, T. L. (2000). Consistent questions of ambiguity in organizational crisis communication: Jack in the Box as a case study. Journal of Business Ethics, 25(2), 143-156.

Ulmer, R. R., \& Sellnow, T. L. (2002). Crisis management and the discourse of renewal: Understanding the potential positive outcomes of crisis. Public Relations Review, 28, 361-365.

Utz, S., Schultz, F., \& Glocka, S. (2013). Crisis communication online: How medium, crisis type and emotions affected public reactions in the Fukushima Daiichi nuclear disaster. Public Relations Review, 39(1), 40-46.

Valackiene, A. (2010). THE EXPRESSION OF EFFECTIVE CRISIS COMMUNICATION IN TODAY'S CORPORATION: THEORETICAL INSIGHTS AND PRACTICAL APPLICATION. Transformation in Business \& Economics, 9.

Valvi, A., \& Fragkos, K. (2013). Crisis communication strategies: A case of British Petroleum. Industrial and Commercial Training, 45(7), $383-391$. doi:http://dx.doi.org/10.1108/ICT-04-2013-0026

van der Meer, T. G., \& Verhoeven, J. W. (2014). Emotional crisis communication. Public Relations Review, 40(3), 526-536. doi:http://dx.doi.org/10.1016/j.pubrev.2014.03.004

van der Meer, T. G., \& Verhoeven, P. (2013). Public framing organizational crisis situations: Social media versus news media. Public Relations Review, 39(3), 229-231.

van der Meer, T. G., Verhoeven, P., Beentjes, H., \& Vliegenthart, R. (2014). When frames align: The interplay between PR, news media, and the public in times of crisis. Public Relations Review, 40(5), 751-761. doi:http://dx.doi.org/10.1016/j.pubrev.2014.07.008

van Zoonen, W., \& van der Meer, T. (2015). The importance of source and credibility perception in times of crisis: crisis communication in a socially mediated era. Journal of Public Relations Research, 27(5), 371-388. doi:10.1080/1062726X.2015.1062382 
Vanhamme, J., \& Grobben, B. (2009). "Too good to be true!”. The effectiveness of CSR history in countering negative publicity. Journal of Business Ethics, 85(2), 273-283.

Vassilikopoulou, A., Siomkos, G., Chatzipanagiotou, K., \& Pantouvakis, A. (2009). Product-harm crisis management: Time heals all wounds? Journal of Retailing and Consumer Services, 16(3), 174-180.

Veil, S. R. (2011). Mindful learning in crisis management. Journal of Business Communication, 48(2), 116-147. doi:10.1177/0021943610382294

Veil, S. R., \& Bishop, B. W. (2014). Opportunities and challenges for public libraries to enhance community resilience. Risk Analysis, 34(4), 721734. doi:10.1111/risa.12130

Veil, S. R., \& Ojeda, F. (2010). Establishing media partnerships in crisis response. Communication Studies, 61(4), 412-429.

Veil, S. R., Reno, J., Freihaut, R., \& Oldham, J. (2015). Online activists vs. Kraft foods: A case of social media hijacking. Public Relations Review, 41(1), 103-108. doi:http://dx.doi.org/10.1016/j.pubrev.2014.11.017

Veil, S. R., \& Yang, A. (2012). Media manipulation in the Sanlu milk contamination crisis. Public Relations Review, $38(5), 935-937$.

Venette, S. (2008). Risk as an inherent element in the study of crisis communication. Southern Communication Journal, 73(3), $197-210$.

Verbeke, W., Viaene, J., \& Guiot, O. (1999). Health communication and consumer behavior on meat in Belgium: from BSE until dioxin. Journal of Health Communication, 4(4), 345-357.

Verhoeven, P., Tench, R., Zerfass, A., Moreno, A., \& Verčič, D. (2014). Crisis? What crisis?. How European professionals handle crises and crisis communication. Public Relations Review, 40(1), 107-109. doi:10.1016/j.pubrev.2013.10.010

Verroen, S., Gutteling, J. M., \& Vries, P. W. (2013). Enhancing Self-Protective Behavior: Efficacy Beliefs and Peer Feedback in Risk Communication. Risk Analysis, 33(7), 1252-1264. doi:10.1111/j.1539-6924.2012.01924.x

Versailles, G. (1999). Surviving the ice storm: the communication manager's perspective. Corporate reputation review, 2(2), $166-175$. doi:1194583941

Verschoor, C. C. (2010). BP still hasn't learned ethical lessons. Strategic Finance, 92(2), 13-15.

Vielhaber, M. E. (1990). Crisis Communication: The Business Communicator's Strategies for Communicating under Stress. Bulletin of the Association for Business Communication, 53(1), 29-31.

Vincze, H. O. (2014). 'The Crisis' as a journalistic frame in Romanian news media. European Journal of Communication, 1-16. doi:10.1177/0267323114541610

Vis, F. (2013). Twitter as a reporting tool for breaking news: Journalists tweeting the 2011 UK riots. Digital Journalism, 1(1), $27-47$. doi:10.1080/21670811.2012.741316

Vlad, I., Sallot, L., \& Reber, B. (2006). Rectification without assuming responsibility: Testing the transgression flowchart with the Vioxx recall. Journal of Public Relations Research, 18(4), 357-379.

Wagenaar, W. A. (1996). Profiling crisis management. Journal of Contingencies and Crisis Management, 4(3), $169-174$.

Wahlberg, D. (1996). Crisis communication, enacted sensemaking, and Prairie Public BroadcastingBROADCASTING. North Dakota Journal of Speech \& Theatre, 9(1).

Waisanen, D. (2015). Comedian-in-Chief: Presidential Jokes as Enthymematic Crisis Rhetoric. Presidential Studies Quarterly, $45(2)$, 335-360.

Wall, M. A. (1997). The Rwanda Crisis An Analysis of News Magazine Coverage. International Communication Gazette, 59(2), $121-134$.

Wan, H. H. (2008). Resonance as a mediating factor accounting for the message effect in tailored communication-Examining crisis communication in a tourism context. Journal of Communication, 58(3), 472-489.

Wan, H.-H., \& Pfau, M. (2004). The relative effectiveness of inoculation, bolstering, and combined approaches in crisis communication. Journal of Public Relations Research, 16(3), 301-328.

Wan, S., Koh, R., Ong, A., \& Pang, A. (2015). Parody social media accounts: Influence and impact on organizations during crisis. Public Relations Review, 41(3), 381-385. doi:10.1016/j.pubrev.2015.01.002

Wang, X. (2012). Combating negative blog posts and a negative incident: A case study of the "Mayday" incident between Juneyao Airlines and Qatar Airways. Public Relations Review, 38(5), 792-795.

Wang, X. (2014). How do people participate in social network sites after crises? A self-determination perspective. Social Science Computer Review, 32(5), 662-677. doi:10.1177/0894439314525116

Ware, B. L., \& Linkugel, W. A. (1973). The spoke in defense of themselves: On the generic criticism of apologia. Quarterly Journal of Speech, 59(3), 273-283. doi:10.1080/00335637309383176

Watson, T. (2007). Reputation and ethical behaviour in a crisis: predicting survival. Journal of Communication Management, 11 (4), $371-384$.

Weber, M., Erickson, S. L., \& Stone, M. (2011). Corporate reputation management: Citibank's use of image restoration strategies during the U.S. banking crisis. Journal of Organizational Culture, Communication and Conflict, 15(2), 35-55. doi:2439571401

Wertz, E. K., \& Kim, S. (2010). Cultural issues in crisis communication: A comparative study of messages chosen by South Korean and US print media. Journal of Communication Management, 14(1), 81-94.

Westerman, D., Spence, P. R., \& Van Der Heide, B. (2014). Social media as information source: Recency of updates and credibility of information. Journal of Computer-Mediated Communication, 19(2), 171-183. doi:10.1111/jcc4.12041

Wickman, C. (2014). Rhetorical framing in corporate press releases: the case of British petroleum and the gulf oil spill. Environmental Communication, 8(1), 3-20. doi:10.1080/17524032.2013.816329

Williams, D. E., \& Olaniran, B. A. (1998). Expanding the crisis planning function: Introducing elements of risk communication to crisis communication practice. Public Relations Review, 24(3), 387-402.

Williams, H. (1957). IV: Some Functions of Communication in Crisis Behavior. Human Organization, 16(2), $15-19$.

Wilson, B., Stavros, C., \& Westberg, K. (2008). Player transgressions and the management of the sport sponsor relationship. Public Relations Review, 34(2), 99-107.

Wisenblit, J. Z. (1989). Crisis management planning among US corporations: Empiric. SAM Advanced Management Journal, $54(2), 31$.

Wrigley, B. J., Salmon, C. T., \& Park, H. S. (2003). Crisis management planning and the threat of bioterrorism. Public Relations Review, 29(3), 281-290.

Wukich, C. (2015). Social media use in emergency management. Journal of Emergency Management, 13(4), $281-295$. doi:10.5055/jem.2015.0242

Diers-Lawson, A. (2017). A state of emergency in crisis communication: An intercultural crisis communication research agenda. Journal of Intercultural Communication Research, 46(1). DOI:10.1080/17475759.2016.1262891. 
Wukich, C., \& Mergel, I. (2015). Closing the Citizen-Government communication gap: Content, audience, and network analysis of government tweets. Journal of Homeland Security and Emergency Management, 12(3), 707-735.

Wybo, J.-L., Fogelman-Soulié, F., Gouttas, C., Freyssinet, É., \& Lions, P. (2015). Impact of social media in security and crisis management: a review. International Journal of Emergency Management, 11(2), 105-128. doi:http://dx.doi.org/10.1504/JJEM.2015.071045

Xiao, Y., Huang, Q., \& Wu, K. (2015). Understanding social media data for disaster management. Natural Hazards, 79(3), 1663-1679. doi:10.1007/s11069-015-1918-0

$\mathrm{Xu}$, J., \& Wu, Y. (2015). Using Twitter in crisis management for organizations bearing different country-of-origin perceptions. Journal of Communication Management, 19(3), 239-253.

Xu, K., \& Li, W. (2013). An ethical stakeholder approach to crisis communication: A case study of Foxconn's 2010 employee suicide crisis. Journal of Business Ethics, 117(2), 371-386. doi:10.1007/s10551-012-1522-0

Yan, Y., \& Kim, Y. (2015). Framing the crisis by one's seat: a comparative study of newspaper frames of the Asiana crash in the USA, Korea, and China. Asian Journal of Communication, 25(5), 486-506. doi:10.1080/01292986.2014.990470

Yin, J., Feng, J., \& Wang, Y. (2015). Social Media and Multinational Corporations' Corporate Social Responsibility in China: The Case of ConocoPhillips Oil Spill Incident. IEEE Transactions on Professional Communication, 58(2), 135-153. doi:10.1109/TPC.2015.2433071

Yum, J.-Y., \& Jeong, S.-H. (2014). Examining the Public's Responses to Crisis Communication From the Perspective of Three Models of Attribution. Journal of Business and Technical Communication, 1050651914560570. doi:10.1177/1050651914560570

Zamoum, K. (2013). Teaching crisis management in Arab universities: A critical assessment. Public Relations Review, 39(1), 47-54. doi:10.1016/j.pubrev.2012.09.005

Zeri, P. (2014). Political blogosphere meets off-line public sphere: Framing the public discourse on the Greek crisis. International Journal of Communication, 8, 17.

Zhang, L., Kong, Y., \& Chang, H. (2015). Media use and health behavior in H1N1 flu crisis: the mediating role of perceived knowledge and fear. Atlantic Journal of Communication, 23(2), 67-80. doi:10.1080/15456870.2015.1013101

Zhao, D., Wang, F., Wei, J., \& Liang, L. (2013). Public reaction to information release for crisis discourse by organization: Integration of online comments. International Journal of Information Management, 33(3), 485-495. doi:http://dx.doi.org/10.1016/j.ijinfomgt.2013.01.003

Zhao, Y. (2014). Communication, Crisis, \& Global Power Shifts: An Introduction. International Journal of Communication, 8, 26.

Zhou, H., Shi, L., Mao, Y., Tang, J., \& Zeng, Y. (2014). Diffusion of new technology, health services and information after a crisis: a focus group study of the Sichuan "5.12" Earthquake. The International journal of health planning and management, 29(2), 115-123. doi:10.1002/hpm.2137 